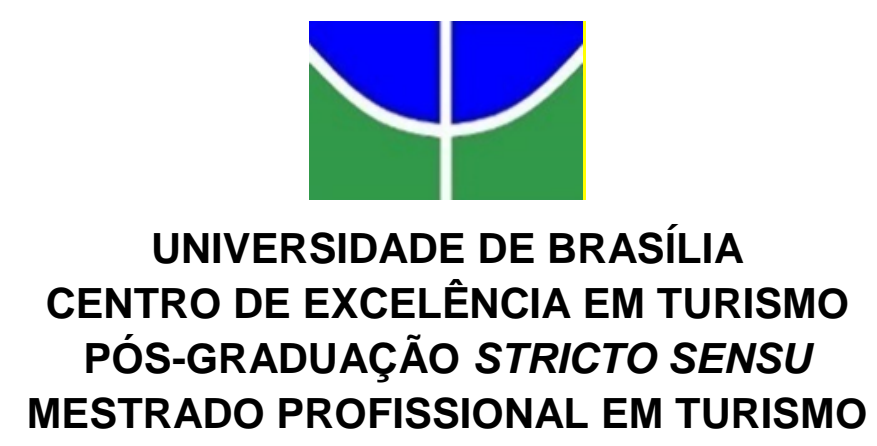

TURISMO RURAL COMUNITÁRIO E A QUESTÃO DE GÊNERO:

O CASO DAS ASSENTADAS RURAIS DE CHAPADINHA-DF

DORCAS SANTOS CABRAL

Brasília 
DORCAS SANTOS CABRAL

\title{
TURISMO RURAL COMUNITÁRIO E A QUESTÃO DE GÊNERO: \\ O CASO DAS ASSENTADAS RURAIS DE CHAPADINHA-DF
}

\begin{abstract}
Dissertação apresentada ao Programa de PósGraduação, Mestrado Profissional em Turismo, do Centro de Excelência em Turismo (CET), da Universidade de Brasília (UnB), na linha de pesquisa Desenvolvimento, Políticas Públicas e Gestão no Turismo, como requisito parcial para a obtenção do título de Mestre em Turismo.
\end{abstract}

Orientadora: Prof. a. Drª . Neuza de Farias Araújo

\section{Brasília-DF}


Cabral, Dorcas Santos

CC117t TURISMO RURAL COMUNITÁRIO E A QUESTÃO DE GÊNERO: O CASO DAS ASSENTADAS RURAIS DE CHAPADINHA-DF / Dorcas Santos Cabral; orientador Neuza de Farias Araújo. -- Brasília, 2017.

$114 \mathrm{p}$.

Dissertaçăo (Mestrado - Mestrado Profissional em Turismo) -- Universidade de Brasilia, 2017.

1. Turismo Rural Comunitário. 2. Gênero. 3. Pluriatividade Rural. 4. Multifuncionalidade Agrícola. I. Araújo, Neuza de Farias, orient. II. Título. 
DORCAS SANTOS CABRAL

TURISMO RURAL COMUNITÁRIO E A QUESTÃO DE GÊNERO: O CASO DAS ASSENTADAS RURAIS DE CHAPADINHA-DF

\title{
BANCA EXAMINADORA
}

\author{
Prof. ${ }^{a}$ Dr. ${ }^{a}$ Neuza de Farias Araújo \\ Universidade de Brasília \\ Orientadora
}
Prof. ${ }^{\text {a }}$ Dr. ${ }^{\text {a }}$ lara Lúcia Gomes Brasileiro
Universidade de Brasília Membro Interno
Prof. ${ }^{a}$ Dr. ${ }^{\text {a }}$ Lana Magaly Pires
Universidade de Brasília Membro Interno

\section{Prof. ${ }^{\text {a }}$ Dr. ${ }^{\text {a }}$ Ana Paula Canotilho \\ Universidade do Porto \\ Membro Externo}

Aprovada

em 02/03/2017 


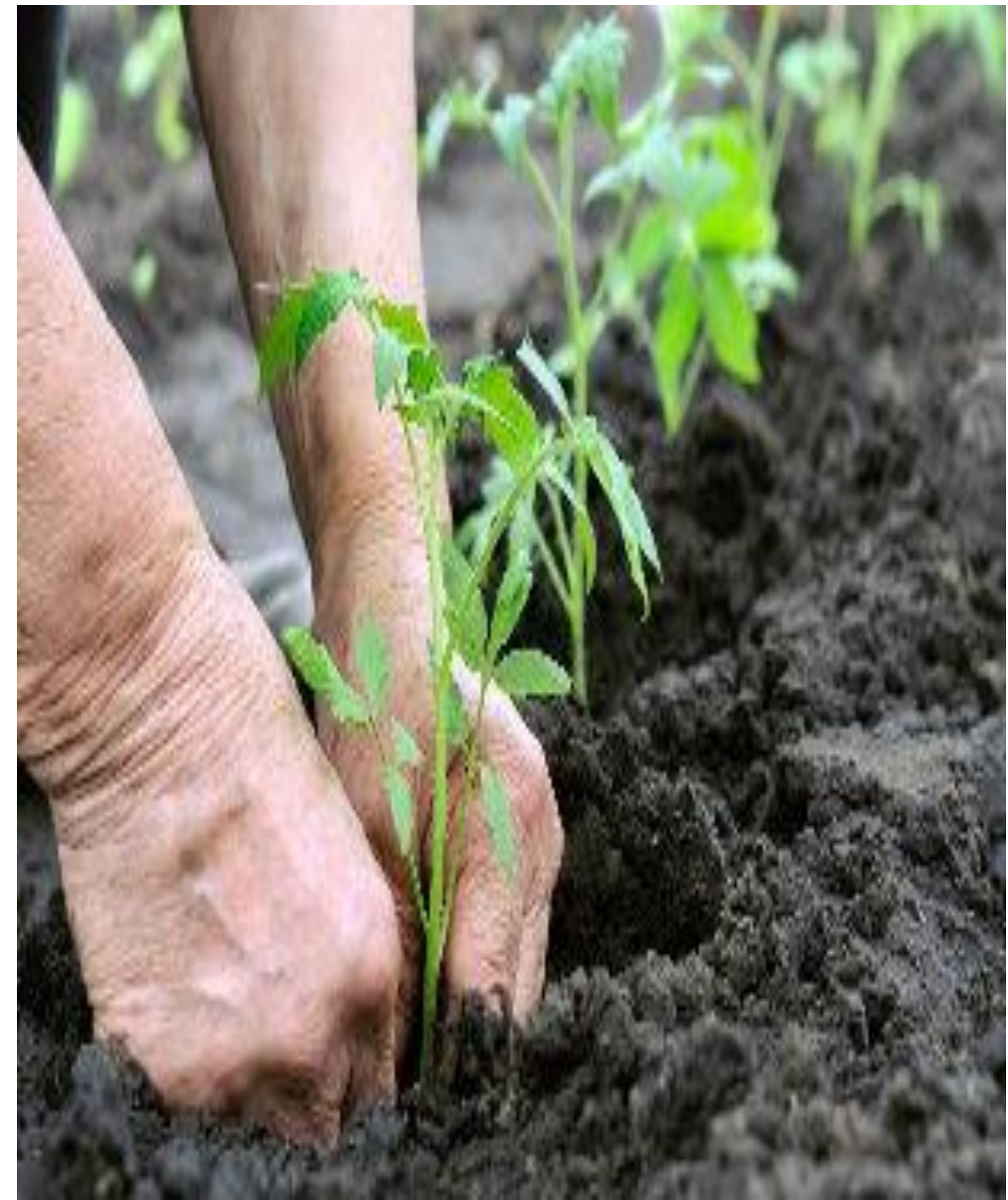

Disse Deus: "Eis que lhes dou todas as plantas que nascem em toda a terra e produzem sementes, e todas as árvores que dão frutos com sementes. Elas servirão de alimento para vocês. Gênesis, 1:29. 


\section{RESUMO}

A pesquisa parte da relevância alcançada pelo Turismo de Base Comunitária (TBC), conceituado na literatura como aquele em que as comunidades, de forma associativa, organizam arranjos produtivos locais, possuindo o controle efetivo das terras e das atividades econômicas associadas à exploração do turismo. Nele, o turista é levado a interagir com o lugar e com as famílias residentes (CORIOLANO, 2009, p. 282). Nesse viés conceitual, observa-se a ascensão do Turismo Rural Comunitário (TRC) como "um turismo com selo próprio", combinando atributos originais e autênticos a partir de comunidades indígenas e rurais, com uma proposta de desenvolvimento para o turismo na escala local, apoiado em bases endógenas humanas, naturais e de infraestrutura - das pequenas comunidades. A correlação do TRC com as questões de gênero confere importância fundamental neste estudo, tendo em vista a presença das mulheres do Assentamento Rural Chapadinha-DF. São agricultoras familiares orgânicas, que têm como principal atividade o cultivo de hortifrutigranjeiros, cujas trajetórias evidenciam a persistência diante das dificuldades, a preocupação com a garantia da segurança alimentar de suas famílias, a vontade de melhorar suas vidas e as de toda a comunidade. A atuação dessas mulheres superou a invisibilidade no âmbito do assentamento e alcançou importantes conquistas sociais. Nesse contexto, a pesquisa sugere a inserção do TRC no assentamento rural, na perspectiva de ampliar a visibilidade ao protagonismo dessas agricultoras, bem como fortalecer as práticas de sustentabilidade em suas dimensões econômica, ambiental, sociocultural e políticoinstitucional no âmbito do assentamento. Esse entendimento encontra espaços de convergências com as teorias da Pluriatividade Rural, que defende a combinação de atividades agrícolas e não agrícolas em uma mesma comunidade, e da Multifuncionalidade Agrícola, que engloba desde as funções de proteção do meio ambiente, até as funções socioeconômicas envolvendo o lazer, a cultura e a distribuição de emprego e renda.

Palavras-chave: Turismo Rural Comunitário. Gênero. Pluriatividade Rural. Multifuncionalidade Agrícola. 


\section{RESUMEN}

La investigación de la relevancia alcanzada por el Turismo de Base Comunitaria (TBC) conceptualizada en la literatura como uno en el que las comunidades se organizan de forma asociativa arreglos productivos locales, que tiene el control efectivo de la tierra y las actividades económicas relacionadas con la explotación del turismo. En ella el turista se lleva a interactuar con el lugar y con las familias residentes (CORIOLANO, 2009, p. 282). En este sesgo conceptual, no es el aumento del Turismo Rural Comunitario (TRC) como "un viaje con sello propio", la combinación de atributos originales y auténticas de comunidades indígenas y rurales, con una propuesta de desarrollo para el turismo en el nivel local, con el apoyo en las bases endógenas - humanas, naturales y de infraestructura - de las comunidades pequeñas. La correlación de TRC con las cuestiones de género proporciona una importancia fundamental en este estudio, dada la presencia de las mujeres en la solución Chapadinha Rural-DF. Son productores familiares orgánicos que se dedican principalmente en el cultivo hortícola, cuyas trayectorias muestran la persistencia en medio de las dificultades, la preocupación por la seguridad alimentaria de sus familias, el deseo de mejorar sus vidas y toda la comunidad. El rendimiento de estas mujeres se sobrepuso a la invisibilidad en virtud del acuerdo y ha logrado importantes logros sociales. En este contexto, la investigación sugiere la inserción de la CVR en el asentamiento rural, con el fin de ampliar la visibilidad del papel de estos agricultores y fortalecer las prácticas de sostenibilidad en sus dimensiones económicas, ambientales, socio-culturales y político-institucionales en el asentamiento. Esta comprensión es espacios de convergencias con las teorías de la Pluriactividad Rural que defienden la combinación de productos agrícolas y no agrícolas en la misma comunidad y la Multifuncionalidad de la Agricultura que va desde las funciones de protección del medio ambiente a las funciones socioeconómicas que implican el ocio, la cultura y la distribución del empleo y los ingresos.

Palabras-clave: Comunidad de turismo rural. Género. Pluriactividad Rural. Multifuncionalidad de la Agricultura. 
À minha mãe, Eunice dos Santos (in memoriam), operária de fábrica de tecidos, na adolescência, em Aracajú, Sergipe, costureira, e uma das primeiras mulheres a pisarem no solo árido e desafiador do Planalto Central, nos anos de 1960, com quatro filhos pequenos. Uma simples e sábia mulher, que orientou os seus filhos a trilharem os caminhos da fé cristã, ensinando-Ihes a serem fortes e corajosos, diante das adversidades da vida.

Ao meu pai, João Adalberto Cabral (in memoriam), pedreiro e pintor, pioneiro em Brasília, regente de coral e pastor evangélico autodidata; sempre entusiasmado, viveu todas as adversidades dos "candangos", com altruísmo, dinamismo e coragem. Aos filhos, deixou um exemplo de vida, pautado no trabalho e nos princípios cristãos de gratidão a Deus.

À minha sogra, Lindaura Cidreira (in memoriam), pescadora, em Santo Amaro da Purificação, na Bahia, costureira, cobradora de bonde, na capital baiana, nos anos 1940; artesã até os 94 anos de idade; conduziu a sua vida com sabedoria $e$ influenciou a conduta dos filhos, netos e bisnetos com a mesma arte com que teceu seus trabalhos em croché.

Ao meu marido, Augusto César, pai dos meus dois filhos, parceiro de uma longa e saudável trajetória de vida.

Às minhas irmãs e irmãos, Gláucia, Jairo, Ruth, Ester e Jackson, exemplos de amor fraternal.

Aos meus filhos, Augusto Gabriel e Elisa, meu equilíbrio entre a razão $e$ a emoção; que este trabalho Ihes sirva de incentivo.

Às pequeninas pérolas e mulheres de amanhã, Aysha, Alice, Clara, Isadora, Kayra e Sofia; que a sabedoria e a força das mulheres do campo thes sirvam de exemplo de trabalho, solidariedade $e$ justiça. 


\section{AGRADECIMENTOS}

A Deus, pela Graça de me conceder saúde e determinação para a realização deste trabalho. "A Ele seja a Glória por toda a eternidade!” (Bíblia, N.T. Filipenses 4:20).

À minha orientadora, Professora Doutora Neuza de Farias Araújo, pelas valiosas contribuições, disponibilidade constante, dedicação, paciência, competência e elevado critério na construção deste trabaho.

Às minhas examinadoras internas, Professora Doutora lara Brasileiro e Professora Doutora Lana Magaly Pires, por me facultarem preciosos conhecimentos nesta jornada acadêmica.

À minha examinadora externa, da cidade do Porto, em Portugal, Professora Doutora Ana Paula Canotilho, pelos valiosos ensinamentos.

Aos demais professores do CET/UnB, que, ao longo deste Mestrado, sempre estiveram abertos ao diálogo profícuo, construtivo e incentivador: Professor Doutor André de Almeida Cunha; Professor Doutor Everaldo Batista Costa; Professor Doutor Luiz Carlos Spiller Pena; Professor Doutor Mario Carlos Beni; Professora Doutora Marutscha Moesch; Professor Doutor Neio Campos.

Aos meus colegas dessa jornada mestranda, Ayako Oiwa, Iraci Nascimento de Castro e Victor João Ramos Alves, pelo compartilhamento nos estudos.

Aos agricultores familiares de Chapadinha-DF, pela hospitalidade às minhas visitas ao assentamento, em especial, às mulheres pela demonstração de simplicidade e riqueza do campo, da natureza e da terra.

Por fim, a todas as mulheres que possuem uma trajetória de vida fincada no trabalho, na luta pelos direitos sociais, na superação do patriarcalismo, no crescimento da participação política, na busca pela autonomia econômica, em especial, àquelas em que tive o prazer de conhecer e conviver, fundamentais referências e inspiração para a realização deste trabalho. 


\section{LISTA DE QUADRO E FIGURAS}

Quadro 1 - Objetivos de Desenvolvimento Sustentável (ODS) ............................49

Figura 1 - Objetivos do Sistema ONU quanto às mulheres. ................................50

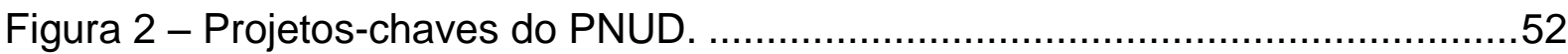

Figura 3 - Mulheres na Marcha das Margaridas, em Brasília-DF. .........................68

Figura 4 - Rodovia DF 001; Chapada da Contagem; Parque Nacional de Brasília, esquerda; Reserva Biológica da Contagem e o Núcleo Rural do Lago Oeste-DF, à direita

Figura 5 - Agricultora do Lago Oeste comercializa geleias na feira, a partir das frutas colhidas na própria propriedade rural. .83

Figura 6 - Rodovia que dá acesso ao NRLO, sentido Posto Colorado-Brazlândia...85

Figura 7 - Agricultor do assentamento em feira popular. .87

Figura 8 - A agricultora em ponto de venda de seus produtos. .88

Figura 9 - Famílias do Assentamento Chapadinha-DF .92

Figura 10 - Processo de regularização dos assentamentos. .93 


\section{LISTA DE ABREVIATURAS}

APP

ASPROESTE

ASTRAF

BNDES

CEASA

CEPAL

EMATER/DF

FAO

FETA

FETRAF-Brasil/CUT

FIB

FIDA

IFB

IFOAM

ISPN

MDA

MTur

NRLO
Área de Proteção Permanente

Associação dos Produtores Rurais do Lago Oeste

Associação dos Trabalhadores Rurais do Assentamento Chapadinha

Banco Nacional do Desenvolvimento Econômico e Social

Centrais de Abastecimento do Distrito Federal S/A

Comissão Econômica para a América Latina

Empresa de Assistência Técnica Rural

Organização das Nações Unidas para a Alimentação e a Agricultura

Federação dos Trabalhadores na Agricultura

Federação Nacional dos Trabalhadores e Trabalhadoras na Agricultura Familiar

Felicidade Interna Bruta

Fundo Internacional de Desenvolvimento Agrícola

Instituto Federal de Educação, Ciência e Tecnologia de Brasília

Federação Internacional de Agricultura Orgânica

Instituto Sociedade, População e Natureza

Ministério do Desenvolvimento Agrário

Ministério do Turismo

Núcleo Rural do Lago Oeste 
OCS

ODM

ODMs

ODS

ONGs

ONU

PAA

PAA

PAIS

PARNA

PAs

PNAE

PNDMTR

PNRA

PNTRAF

PNUD

PRODETUR

PRONAF

REBIO

REDE TRAF

Rede TRAF
Organização de Controle Social

Objetivos do Desenvolvimento do Milênio

Objetivos de Desenvolvimento do Milênio

Objetivos de Desenvolvimento Sustentáveis

Organizações Não Governamentais

Organização das Nações Unidas

Programa de Aquisição de Alimentos

Programa de Aquisição de Alimentos

Produção Agroecológica Integrada Sustentável

Parque Nacional

Projetos de Assentamento

Programa Nacional de Alimentação Escolar

Programa Nacional de Documentação da Mulher Trabalhadora Rural

Programa de Assentamento de Trabalhadores Rurais.

Programa Nacional de Turismo Rural na Agricultura Familiar

Programa das Nações Unidas para o Desenvolvimento

Programas Regionais de Desenvolvimento do Turismo

Programa Nacional de Fortalecimento da Agricultura

Familiar

Reserva Biológica

Rede de Turismo Rural na Agricultura Familiar

Turismo Rural de Agricultura Familiar 
SEAGRI/DF

SEBRAE

TBC

TRBC

TRC

TUCUM

UnB
Secretaria de Agricultura, Abastecimento e

Desenvolvimento Rural

Serviço de Apoio às Micro e Pequenas Empresas

Turismo de Base Comunitária

Turismo Rural de Base Comunitária

Turismo Rural Comunitário

Rede Cearense de Turismo Comunitário

Universidade de Brasília 


\section{SUMÁRIO}

APRESENTAÇÃO

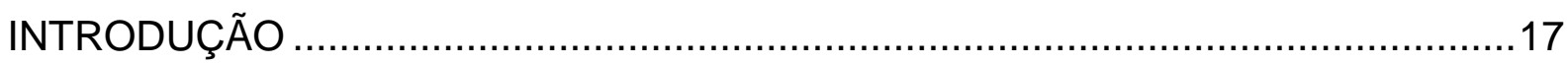

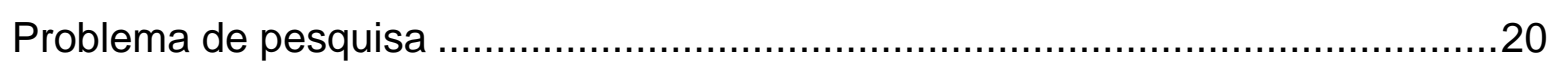

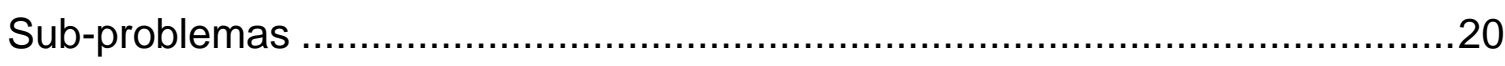

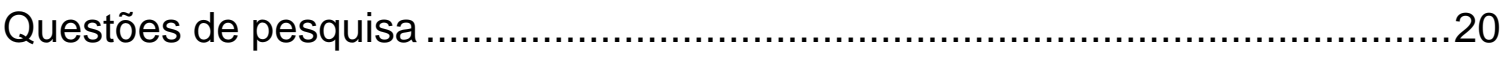

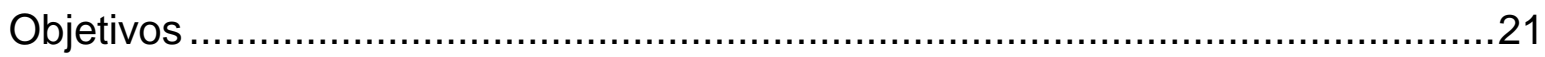

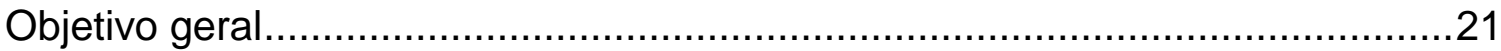

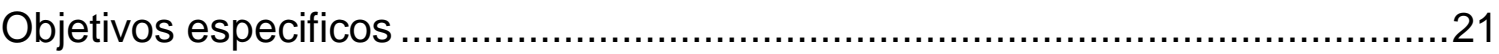

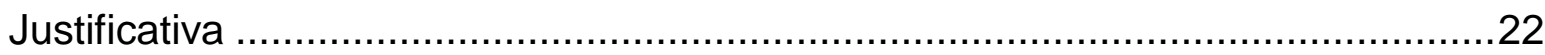

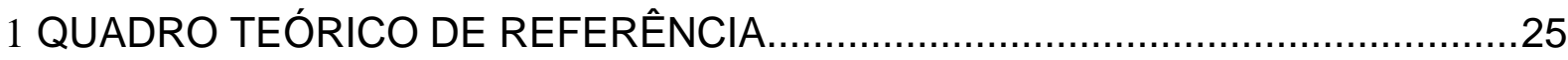

1.1 Turismo como fenômeno social ...........................................................25

1.2 Turismo de Base Comunitária (TBC) …………….................................28

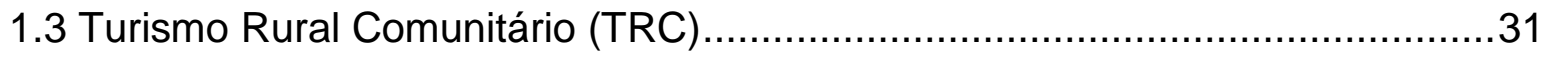

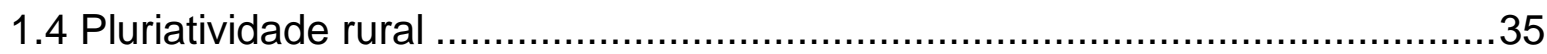

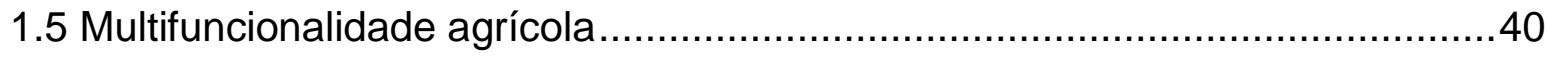

1.6 Turismo nos Espaços Rurais de Assentamento ..........................................44

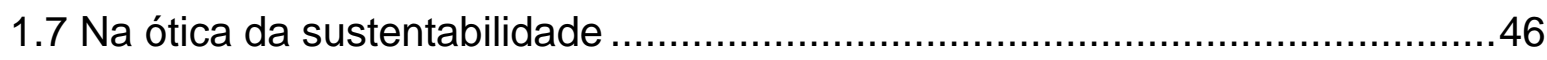

1.7.1 Desenvolvimento sustentável e a ruralidade .........................................56

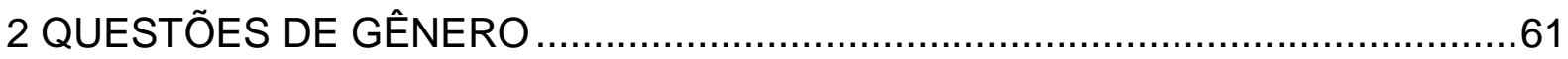

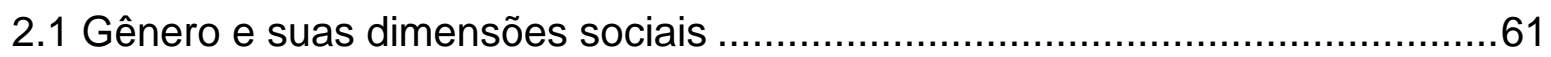

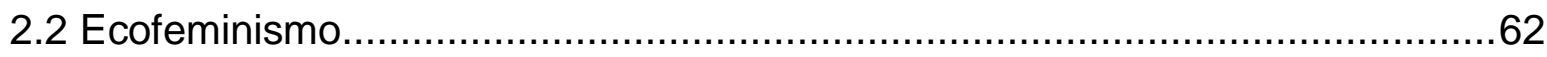

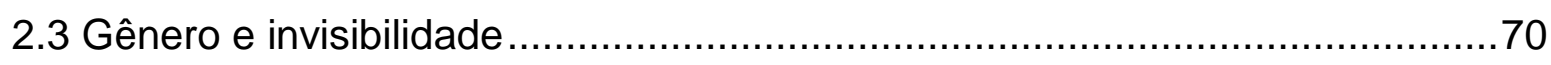

2.4 Gênero em assentamentos rurais .............................................................

3 O CAMINHO TEÓRICO-METODOLÓGICO.........................................................73 
3.1 O tipo de pesquisa - Método qualitativo ……….......................................73

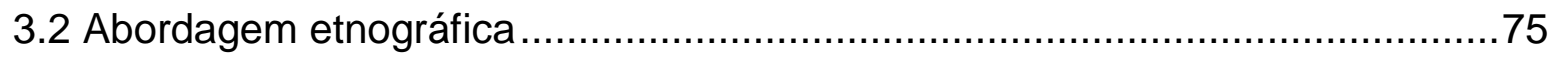

3.3 Procedimentos técnicos de coleta de dados .................................................

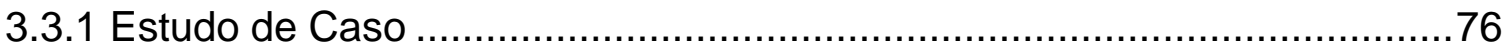

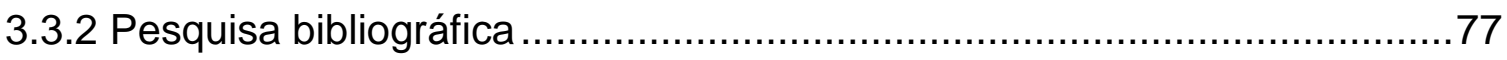

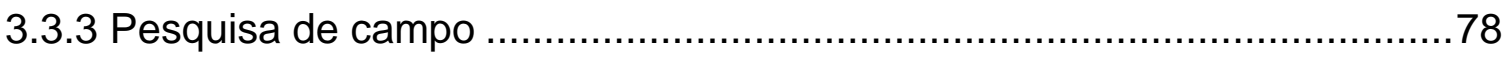

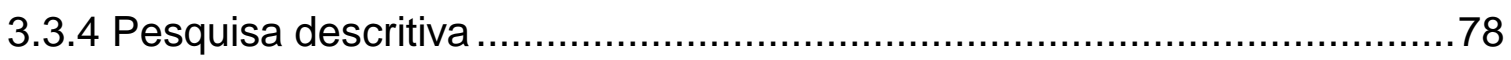

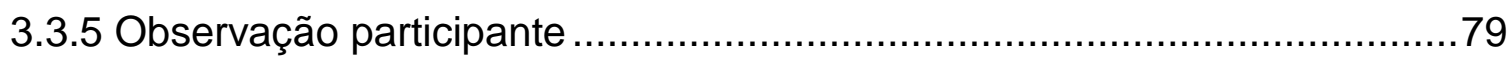

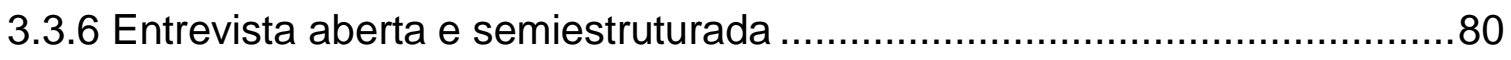

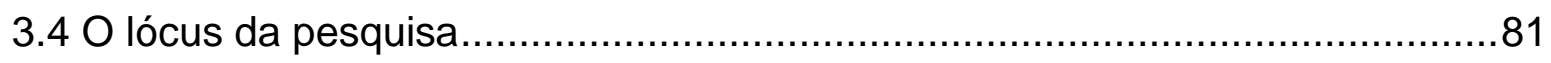

3.4.1 Lago Oeste (DF) - Vocação ecoturística ...............................................81

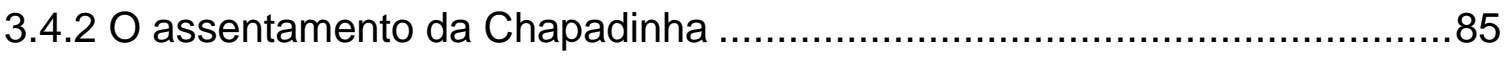

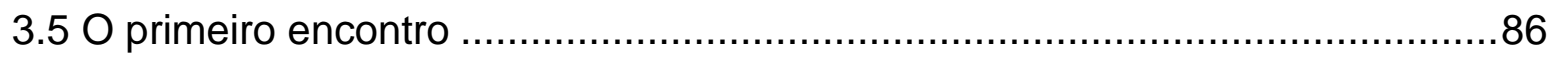

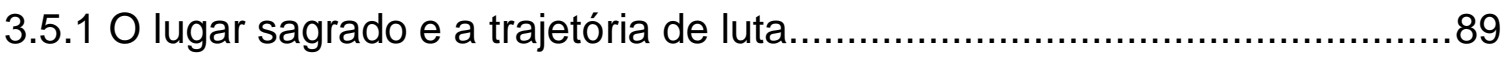

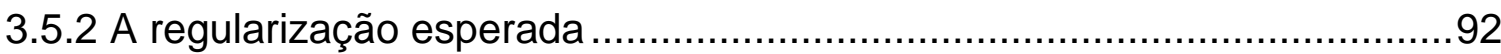

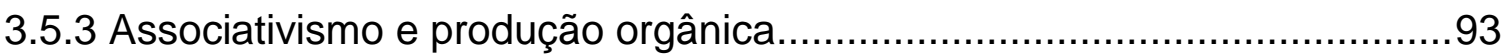

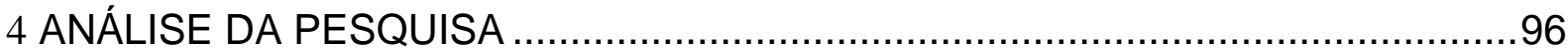

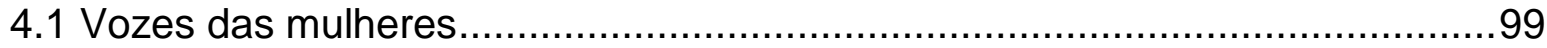

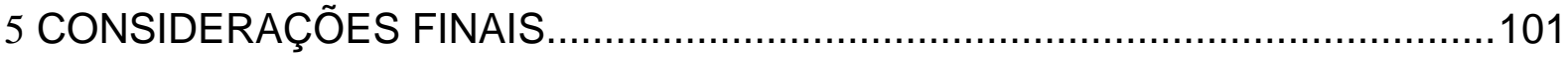

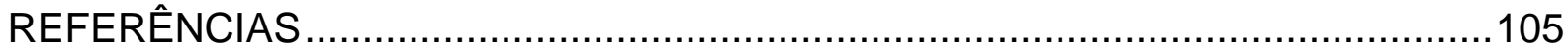

APÊNDICE I - ROTEIRO DA ENTREVISTA SEMIESTRUTURADA APLICADA NO ASSENTAMENTO RURAL DE CHAPADINHA-DF .........................................112 


\section{APRESENTAÇÃO}

Já que duvido, penso; já que penso, existo ${ }^{1}$.

Descartes (1596-1650)

Na década de 1960 cheguei a Brasília com a minha mãe e três irmãos ao encontro do meu pai, que já trabalhava na construção da nova capital. Recordo-me da poeira fina e vermelha, do frio, dos barracos de madeira improvisados, muitos índios, cujas tribos já estavam aqui desde o século XVIII, que se viam perdidos pelas ruas, inconformados com a invasão em suas terras. Terra de ninguém, ou melhor, terra de aventureiros. Nesse ambiente, as mulheres pioneiras entraram de corpo e alma. Isoladas, longe da cidade em que viviam, cobertas pelo manto do anonimato, eram fortes e solidárias. Contudo, eram invisíveis. Nunca ou quase nunca, a mulher tinha nome e sobrenome.

Aos poucos a poeira foi baixando, a pele foi se acostumando com o clima seco que rachava os lábios e os pés até sangrar, as crianças crescendo e as mulheres foram se acomodando nos postos de trabalho e/ou no desconforto de suas casas de madeira.

Nesse ambiente vivi a minha infância. Ao lado de uma mulher forte, corajosa e incansável na lida diária dos cuidados com a família.

Hoje, no século XXI, a capital federal se tornou uma grande cidade, uma metrópole. No entanto, muitas mulheres ainda vivem em barracos de madeira sem qualquer conforto, trabalham no campo faça chuva ou sol, são invisíveis na sociedade, algumas ainda não têm nome nem sobrenome. Essas mulheres estão nas periferias das cidades ou no campo. Suas trajetórias de vida me inspiraram a conduzir esta pesquisa no assentamento rural, em Chapadinha-DF.

Porém, outros caminhos convergiram para a definição do tema central desta pesquisa.

Os cursos de graduação em Turismo, de especialização técnica em Turismo Rural e pós-graduação em Metodologia de Ensino Superior, deixaram-me uma lacuna em termos profissionais. A visão mercantilista do turismo me inquietava, e me

\footnotetext{
${ }^{1}$ Texto original: "Puisque je doute, je pense; puisque je pense, j'existe". Tradução desta autora.
} 
conduziu na busca de suporte científico que permitisse apontar essa atividade a favor de segmentos sociais mais explorados e menos favorecidos com a exploração turística. Na busca desse suporte, ingressei como aluna especial no Centro de Excelência em Turismo (CET-UnB), na disciplina de Hospitalidade, ministrada pela Profa. Dra. lara Brasileiro, examinadora interna desta dissertação.

Essa disciplina mudou o meu olhar sobre a "hospitalidade" para além da concepção mercadológica dentro do fenômeno turístico, a partir da compreensão de Derrida (2003), que a vê como uma "reciprocidade de responsabilidade entre o eu e o outro" e as relações provenientes do encontro e do contato estabelecido entre aquele que a princípio nos parece diferente, por características físicas ou culturais, ou até mesmo por ser desconhecido. E corroboro o conceito do ciclo da dádiva de Marcel Mauss, cujo entendimento nos diz que "(...) a partir do encontro entre um anfitrião e um hóspede, a dádiva pode aí se manifestar de diferentes maneiras: na hospedagem, na alimentação, no entretenimento, na dedicação ao anfitrião, no acolhimento".

Esse olhar se ampliou a partir da orientação da Prof ${ }^{a}$. Drª . Iara Brasileiro, no sentido de abordar as questões da sustentabilidade em suas diversas dimensões, à luz dos conceitos de Enrique Leff, Bursztyn e Bursztyn, Ignacy Sachs, Abramovay e das reflexões teológicas e filosóficas do Papa Francisco.

Ainda como aluna especial, cursei a disciplina "Turismo, Trabalho e Gênero", ministrada pela Profạ. Drạ. Neuza de Farias Araújo, minha Orientadora. Essa disciplina ampliou a compreensão do turismo como um fenômeno social, político, cultural, econômico e ambiental; do turismo como uma oportunidade de trabalho e renda para pequenas comunidades urbanas ou rurais; do turismo como uma possibilidade de dar visibilidade ao trabalho da mulher do campo, inserindo-a como sujeito de suas ações nas atividades turísticas rurais.

A compreensão dos significados das experiências dos atores e atrizes sociais no contexto da luta pela terra e sua produção, dos que buscam plantar e colher, a história da luta política dos trabalhadores rurais SEM TERRA, revelados na tese de Doutorado da Prof ${ }^{a}$. Dr . Lana Magaly Pires, outra examinadora interna desta dissertação, trouxe um sentido inspirador na minha imersão como observadora participante junto aos assentados rurais.

Igualmente valiosa a contribuição da Prof ${ }^{a}$. Dr ${ }^{a}$. Ana Paula Canotilho, examinadora externa desta dissertação, ao sugerir a inserção do Ecofeminismo 
nesta pesquisa, visto que a combinação das palavras "ecologia" e "feminismo" abraça a ideia de que a opressão das mulheres e a opressão ou destruição da natureza estão intimamente ligadas. Elementos do movimento feminista, do movimento da paz, dos movimentos ambientalista e verde podem ser vistos no Ecofeminismo: todos propõem profundas mudanças na ordem natural, baseadas na justiça social e preservação ambiental, além de lutar pelos direitos sexuais e reprodutivos femininos.

O encontro desses conceitos com a minha vivência junto às mulheres pioneiras de Brasília confirmaram o objeto de pesquisa desta dissertação, que se apresenta como uma proposta de ampliar a visibilidade e o empoderamento das mulheres rurais, por meio da inserção do assentamento rural na cadeia produtiva do turismo, em cujo contexto social, econômico, cultural e ambiental, manifesta-se a prática do acolhimento, com ênfase na visibilidade ao trabalho da mulher rural. 


\section{INTRODUÇÃO}

Este trabalho surgiu a partir das reflexões trazidas à luz dos conceitos de Gênero, Hospitalidade, Etnografia, Ecofeminismo e Sustentabilidade, correlacionados ao Turismo Rural, os quais me foram generosamente apresentados pelas Prof. ${ }^{a}$ Dr. ${ }^{a}$ Neuza de Farias de Araújo, minha orientadora, Prof. ${ }^{a}$ Dr. $\stackrel{a}{ }$ lara Brasileiro e Prof. ${ }^{a}$ Dr.. Lana Magaly Pires, examinadoras internas, do Centro de Excelência em Turismo/Universidade de Brasília e da Prof. ${ }^{\underline{a}}$ Dr. $\stackrel{\text { a }}{\text { Ana Paula }}$ Canotilho, examinadora externa, da Universidade de Porto, Portugal.

Os resultados da pesquisa realizada deram suporte à elaboração desta dissertação de Mestrado Profissional em Turismo, dentro do Programa de PósGraduação do Centro de Excelência em Turismo da Universidade de Brasília. Com o título de Turismo Rural Comunitário e a questão de gênero: o caso das assentadas rurais da Chapadinha-DF, tal estudo pretendeu analisar a possibilidade de inserção da modalidade do turismo rural comunitário no Assentamento Rural de ChapadinhaDF, como favorecedora da ampliação da visibilidade das mulheres, a partir da correlação das práticas agroecológicas já desenvolvidas pelas agricultoras.

As inquietações pertinentes às relações de gênero no âmbito da família e do trabalho acenderam o desejo de colocar em discussão o turismo e as questões de gênero nos assentamentos rurais, direcionando um olhar sobre as mulheres integrantes do Assentamento Rural de Chapadinha-DF, atentando quanto às suas atuações como mulheres e trabalhadoras e a sua visibilidade enquanto sujeitos promotores de turismo rural comunitário.

As razões para a escolha deste tema alicerçaram-se a partir da ressignificação das atividades produtivas das mulheres, cuja presença na produção agrícola familiar é um fato, mesmo na invisibilidade. Esse quadro vem sofrendo alterações a partir da emergência das mulheres rurais nos movimentos sociais, o que vem proporcionando o seu aparecimento como sujeito político, colaborando para o rompimento da sua invisibilidade como trabalhadoras urbanas e/ou rurais. As questões de gênero e de geração nos espaços da reforma agrária são temas abordados e defendidos com certa veemência nos assentamentos rurais dispersos pelo Brasil. 
Tais assentamentos são integrados por famílias que retornam ao campo como forma de amenizar as dificuldades enfrentadas nas cidades, o que demonstra que há uma nova ruralidade ou uma nova sociologia rural. Essa nova ruralidade comporta a adoção de novas práticas, sendo o turismo nesses espaços um possível vetor para o desenvolvimento de atividades relacionadas ao meio rural. E "na realidade, esta nova ruralidade, na qual surgem novas relações entre o campo e a cidade, se mescla com a multifuncionalidade" (RAMIRO, 2010 apud GRAMONT; DIAS, 2011).

Essa nova ruralidade apresenta um avanço na diversidade de formas familiares que se manifestam por meio da multifuncionalidade do espaço agrário e a pluriatividade agrícola. A conjugação desses conceitos tem o potencial de levar a uma reorientação do modelo de desenvolvimento do meio rural brasileiro, que pode vir por meio de um modelo sustentável, ecologicamente correto e socialmente igualitário, e que proporcione a fixação e manutenção de famílias no campo, com atividades ligadas à agricultura orgânica, agroecologia, turismo rural, ecoturismo e outras práticas adequadas ao meio rural.

A relação entre o turismo e o desenvolvimento local é inerente ao Turismo de Base Comunitária, o qual já faz parte da realidade social e turística do Brasil graças às suas múltiplas iniciativas em várias regiões com o envolvimento de muitas comunidades. No universo do turismo rural, as atividades comunitárias são denominadas como Turismo Rural de Base Comunitária (TRBC) ou Turismo Rural Comunitário (TRC). Nesse segmento, os desafios econômicos, sociais e ambientais são interligados dentro de uma dimensão de tempo, espaço, história, memória e territorialidade.

Considerando esse quadro, parte-se da premissa de que o turismo rural comunitário representa uma oportunidade para melhorar o bem-estar das comunidades assentadas, para assegurar o bem-estar comum e garantir a sobrevivência de seus membros, preservando, contudo, sua própria identidade cultural.

A visão mercantilista do turismo trouxe-me inquietação, e por isso conduziume à procura de suporte científico que permitisse apontar essa atividade a favor de segmentos sociais mais explorados e menos favorecidos com a especulação turística. Nas relações de gênero e turismo rural, as mulheres se destacam como fator essencial na gestão ambiental, na produção de alimentos e na reprodução 
social, ao mesmo tempo em que contribuem na transição para uma "economia verde". Um quarto da população feminina mundial vive no campo. São líderes, tomadoras de decisão, trabalhadoras, empresárias e fornecedoras de serviços. Sua contribuição é vital para o bem-estar das famílias e das comunidades.

No entanto, a percentagem de mulheres na tomada de posição é muitíssimo baixa; não é a mesma que a das fornecedoras de serviços. As mulheres continuam sub-representadas como trabalhadoras familiares não remuneradas. Essa tendência deve-se, em parte, a uma mudança na reestruturação econômica com o abandono do trabalho agrícola, que consistia, em grande parte, nas atividades de subsistência e de pequena escala. Portanto, pode afirmar-se que muitas mulheres trabalhadoras permanecem numa situação de inferioridade face ao emprego e em profissões (OIT, 2016) $)^{2}$.

Nesse sentido, o turismo pode ser percebido como um vetor dessa busca feminina ao tornar as mulheres "visíveis" tanto no âmbito do assentamento rural quanto da sociedade na qual se inserem, por meio do "olhar do turista".

Esta pesquisa é de caráter qualitativo com abordagem etnográfica, na perspectiva de obter um quadro holístico dos sujeitos do estudo. Para tanto, utilizaram-se as técnicas de entrevista semiestruturada com os integrantes do Assentamento Rural Chapadinha do Distrito Federal, bem como da observação participante, na intenção de obter uma ampla e detalhada visão do objeto de pesquisa, com nível descritivo. As pesquisas, bibliográfica e documental, permitiram a construção de um referencial teórico a fim de fundamentar as reflexões acerca das categorias em análise e as interpretações dos dados coletados. Na pesquisa de campo buscou-se identificar os participantes em um cenário global, ou seja, os cotidianos, a rotinas das pessoas - suas instituições, seus comportamentos interpessoais, suas produções materiais e suas crenças.

\footnotetext{
${ }^{2}$ A percentagem de mulheres que assumem a presidência das direções é ínfima: em metade dos países abrangidos no inquérito da OIT nenhuma empresa tinha uma administração liderada por uma mulher. Em nível mundial, $87 \%$ das empresas são dirigidas por homens e $13 \%$ comandadas por mulheres. A Noruega tem a maior proporção de empresas com presidentes mulheres $(13,3 \%)$, seguida da Turquia $(11,1 \%)$.
} 
PROBLEMA DE PESQUISA

$\checkmark$ A atividade turística é propícia para a ampliação da visibilidade das mulheres do Assentamento Rural Chapadinha-DF?

\section{Sub-problemas}

$\checkmark$ Como o protagonismo das mulheres do Assentamento Rural Chapadinha-DF poderá contribuir na implantação da atividade turística à luz dos conceitos do Turismo Rural Comunitário?

$\checkmark$ O contexto de organização, territorialidade e relações de poder no Assentamento Rural Chapadinha-DF é propício para o desenvolvimento do Turismo Rural Comunitário?

$\checkmark$ Como envolver a comunidade em uma perspectiva de Turismo Rural Comunitário?

\section{Questões de pesquisa}

$\checkmark$ É possível, dentro da organização social do Assentamento Rural Chapadinha- DF, a inserção do Turismo Rural Comunitário?

$\checkmark$ O Turismo Rural Comunitário permitirá outras formas de inserção econômica às mulheres agricultoras? 
OBJETIVOS

\section{Objetivo geral}

Analisar a possibilidade de inserção da modalidade do turismo rural comunitário no Assentamento Rural de Chapadinha-DF como favorecedora da ampliação da visibilidade das mulheres, a partir da correlação das práticas agroecológicas já desenvolvidas pelas agricultoras.

\section{Objetivos especificos}

$\checkmark$ Identificar as participações das mulheres do Assentamento Rural Chapadinha-DF dentro da contextualização do Turismo Rural Comunitário (TRC);

$\checkmark$ Verificar as expectativas dos assentados rurais em relação a implantação do TRC;

$\checkmark$ Identificar as potencialidades do Assentamento Rural Chapadinha-DF como atrativo turístico;

$\checkmark$ Identificar os recursos inerentes ao turismo no Assentamento Rural de Chapadinha-DF que poderão possibilitar a visibilidade do trabalho das mulheres com as práticas do Turismo Rural Comunitário. 


\section{JUSTIFICATIVA}

A centralidade do fenômeno Turismo é uma atividade em que o centro de atenção é a pessoa: é das pessoas e para as pessoas. O contato intercultural entre anfitriões e os hóspedes é particularmente importante.

BURNS e HOLDEN (1995)

O Turismo, enquanto setor econômico, é reconhecido como importante gerador de divisas capaz de promover oportunidades de trabalho e renda e de contribuir para a redução das desigualdades regionais e sociais' Porém, o seu entendimento, para além do foco econômico, tem mobilizado os teóricos contemporâneos na busca por respostas a questionamentos sobre a multinterdisciplinaridade do fenômeno do turismo, os sujeitos produtores e consumidores, os impactos dessa atividade sobre a economia, as comunidades locais e o meio ambiente natural (MOESCH, 2002).

A clareza epistemológica no tratamento do turismo permite considerar as relações desse fenômeno no campo social, cultural, comunicacional, econômico, ambiental e subjetivo. O turismo é conceituado em muitos momentos e por diversos autores, desde Bodio e Von Wiese, Dumazedier, Macintosch, Krippendorf, Jafarl, entre outros. Das abordagens contemporâneas, tem-se em Fuster (2001) uma visão do turismo e suas relações com o sujeito consumidor, a infraestrutura do núcleo receptivo e os efeitos produzidos na comunidade receptora.

Turismo é, de um lado, conjunto de turistas; do outro, os fenômenos e as relações que esta massa produz em consequência de suas viagens. [...] é todo o equipamento receptivo [...] que o núcleo deve habilitar, para atender às correntes [...] é o conjunto das organizações privadas ou públicas que surgem, para fomentar a infraestrutura e a expansão do núcleo, as campanhas de propaganda [...] Também são os efeitos negativos ou positivos que se produzem nas populações receptoras (FUSTER, 2001).

Os conceitos em turismo encontram em Moesch (2002) o entendimento da complexidade do fenômeno turístico, que envolve a sociologia, a temporalidade, a espacialidade e os sujeitos: 
Turismo é um fenômeno complexo e, antes de ser econômico, é uma experiência social. Envolve sujeitos consumidores que se deslocam no tempo e no espaço para satisfazer as suas necessidades físicas imediatas e também os seus imaginários e, os sujeitos produtores de bens e serviços turísticos (MOESCH, 2002).

Na visão de Moesch (2002), além das questões econômicas associadas ao turismo, as experiências tradicionais demonstram que nem sempre ele está relacionado ao desenvolvimento das localidades onde se estabelece, apesar de seu significativo crescimento e do notável aumento das receitas que provoca. É crescente a preocupação quanto aos significativos impactos sociais e ambientais, geralmente associados ao turismo de massa.

A lacuna inerente aos aspectos econômicos, sociais e ambientais do turismo de massa gera mudanças de comportamentos em comunidades que se organizam proativamente em empreendimentos cooperativos e associativos ligados ao turismo. Surge, a partir daí, o Turismo de Base Comunitária (TBC) como "um modelo de desenvolvimento orientado pelos princípios da economia solidária, do associativismo, da valorização da cultura local e, principalmente, do protagonismo das comunidades locais" (MTur, Edital 001/2008).

O TBC tem uma abrangência urbana ou rural. Relaciona-se, dentre outros aspectos, à "história de luta pela posse da terra, pela preservação do meio ambiente ou mesmo pelo direito ao modo de vida tradicional que uniu comunidades e formou a base para o desenvolvimento de um outro turismo" (CORIOLANO, 2009). No ambiente predominantemente rural, têm-se apontado iniciativas que se identificam como de Turismo Rural Comunitário. Esse modelo de turismo envolve a implementação de infraestruturas turísticas de pequeno porte, integradas ao meio natural e construído, que valorizam o intercâmbio entre culturas, a integração das atividades turísticas, criando mecanismos autônomos de gestão territorial que regulam a relação entre turistas e comunidades.

Conforme atesta Maldonado (2009), o TRC surgiu nas duas últimas décadas dentro de um contexto de grandes mudanças econômicas, políticas e sociais. Dirigese a um nicho de mercado constituído por viajantes em busca de experiências pessoais e enriquecedoras. Diversas comunidades estão se abrindo para o mercado graças a "um turismo com selo próprio", combinando atributos originais e autênticos, mas sem perder a sua alma. 
O Turismo Rural Comunitário é considerado como uma atividade não agrícola inserida na pluriatividade rural. Schneider (2003) o conceitua como

[...] um fenômeno através do qual membros das famílias de agricultores que habitam no meio rural optam pelo exercício de diferentes atividades, ou mais rigorosamente, optam pelo exercício de atividades não-agrícolas, mantendo a moradia no campo e uma ligação, inclusive produtiva, com a agricultura e a vida no espaço rural (SCHNEIDER, 2003, p. 91).

Sendo assim, o que caracteriza e define a pluriatividade é a combinação de atividades agrícolas e não agrícolas em uma mesma família ou comunidade, que tanto pode ser um recurso do qual a família faz uso para garantir a reprodução social do grupo que the corresponde, como também pode representar uma estratégia individual de um integrante familiar.

Também no ambiente rural aplica-se o conceito da multifuncionalidade, que se vincula a um "espaço" ou território com a possibilidade de auxiliar nas políticas de inserção social. No Brasil, tem-se como exemplo a reforma agrária em que, num contexto mais amplo de oportunidades não ligadas estritamente à produção agrícola, podem-se inserir outras atividades ligadas ao campo, como o turismo rural e o ecoturismo, entre outras, todas elas incorporadas à valorização e preservação ambiental e cultural da região. Sob a ótica da multifuncionalidade, as soluções agrícolas para problemas de inserção social no meio rural devem se pautar na produção agroalimentar com práticas ecologicamente corretas e sustentáveis, e que priorizem a relação e o respeito do homem com a natureza.

No bojo dessas reflexões, as questões de gênero no ambiente rural assumem um papel de destaque, quando se percebe a emergência das mulheres rurais nos movimentos sociais que vem proporcionando o seu aparecimento como sujeito político, rompendo sua invisibilidade no contexto público e privado. Mesmo na invisibilidade, elas estão ocupando terras, plantando, colhendo, e cultivando o desejo de ter uma terra livre e usufruí-la com seu trabalho.

Nesse sentido e no entendimento de Lunardi (2010), a inserção do turismo rural pode ser analisada sob dois vieses distintos: de autonomia socioeconômica e de afirmação da posição invisível das mulheres no mercado de trabalho. Como impacto positivo, pode-se evidenciar a autonomia gerada pela atividade lucrativa e [...] como negativo, destaca-se a multifuncionalidade da mulher rural ou a multiplicidade de atividades desenvolvidas por ela. 


\section{QUADRO TEÓRICO DE REFERÊNCIA}

Este capítulo busca situar o objeto desta dissertação em um contexto teórico interdisciplinar, considerando, para tanto, as contribuições de autores em torno de conceitos sobre turismo como fenômeno social, turismo de base comunitária, turismo rural comunitário, pluriatividade e multifuncionalidade, sustentabilidade, assentamentos rurais e as questões de gênero.

\subsection{TURISMO COMO FENÔMENO SOCIAL}

O turismo é uma atividade que repercute e se manifesta na multiplicidade de fenômenos econômicos, antropológicos, sociológicos, entre outros. Essa multiplicidade deriva da sua essência que reside em tempo livre, recursos econômicos e necessidade de recreação (CENTENO apud MOESCH, 2002).

Dentro de uma sociedade, o turismo exerce um papel socializador, pois ele possibilita 0 encontro entre pessoas de diferentes culturas, diminui as distâncias étnicas ao permitir um maior conhecimento dos outros e dos seus costumes, e contribui para uma maior compreensão entre as mais distintas populações (MARUJO, 2005).

O turismo é, portanto, um fenômeno social, político, cultural, econômico e ambiental; é interdisciplinar ou multidisciplinar, o que o conduz para definições e explicações no campo da Psicologia, Geografia, Economia, Antropologia, História e a própria Sociologia.

O entendimento do fenômeno social no turismo é citado na literatura em diversos momentos e por conceituados autores. De acordo com Fuster (2001), a sociologia do turismo estaria fixada no comportamento turístico dos grupos humanos, das suas relações com o núcleo receptor e dos fenômenos originados com a sua presença. As categorias de "viajante" e de "receptor" são citadas pelo autor como duas massas que estariam sob o domínio da sociologia.

No campo da Sociologia, o turismo apresenta múltiplas implicações diretamente relacionadas com a sociedade e com os grupos e indivíduos que 
produzem fatos sociais os quais dão sentido às suas ações e entram em conflitos por diversos interesses. Ou seja, a sociologia ajuda a caracterizar o turismo como uma prática social.

Nesse viés conceitual, Gastal (2004) nos traz o entendimento de que, "antes de ser um fenômeno econômico, o turismo é uma experiência social que envolve pessoas". Corroborando essa compreensão, Moesch (2000) afirma que turismo é um processo humano, que ultrapassa o entendimento como função de um sistema econômico. É um fenômeno complexo e, antes de ser econômico, é uma experiência social que envolve sujeitos consumidores que se deslocam no tempo e no espaço para satisfazer suas necessidades físicas imediatas e também os seus imaginários e sujeitos produtores de bens e serviços turísticos.

Os sujeitos, elemento central do fenômeno social do turismo, são colocados na literatura sob diversos olhares. Em Morin (1995), o sujeito consumidor no turismo, "[...] revela elementos de sua humanidade, pois conjuga atos de prosa e de poesia, quando vive a participação, a quebra da rotina [...].

O turismo é um fenômeno social reconhecido, especialmente, por dois atores (turista e anfitrião) que desempenham papéis fundamentais dentro da atividade turística. Assim sendo, a sociologia do turismo procura compreender a natureza da interação entre os turistas e os anfitriões, bem como analisar os impactos sociais e culturais que o turismo provoca nas sociedades receptoras e emissoras (MARUJO, 2005, p. 18).

A Sociologia teve e tem um particular interesse sobre as interações que ocorrem entre os visitantes e residentes, principalmente quando esses têm diferentes valores, expectativas e comportamentos padrões que podem ser expressos ou não em normas sociais (MARUJO, 2005 apud JAFARI; RITCHIE, 1981).

Fuster (1974) afirma que a Sociologia do Turismo deve estudar as relações e os fenômenos causados pela presença do turista num determinado núcleo receptor. Já Moesch (2002, p. 22) considera a importância da sociologia como instrumento pedagógico aplicável ao turismo, afirmando que "nisso residiria a aplicação central da sociologia como teoria de génese turística, cabendo-lhe ainda um papel importante, o pedagógico: aconselhar os visitantes sobre as idiossincrasias dos visitados (MOESCH, 2002, p. 22). 
Nas análises do sociólogo John Urry (1996, p. 16, 18), há uma preocupação para além dos estudos tradicionais sobre o impacto nas sociedades receptoras do turismo, com o comportamento do turista. Esse sociólogo centra-se especialmente no processo do "olhar" do turista em que, segundo ele,

não existe um único olhar do turista enquanto tal. Ele varia de acordo com a sociedade, o grupo social e o período histórico. Tais olhares são construídos por meio da diferença. O olhar é construído através de signos, e o turismo abrange uma coleção de signos (URRY, 1996, p. 16).

A Sociologia do Turismo associa-se a várias temáticas, confirmando a interdisciplinaridade do fenômeno turístico. Numa associação com a Antropologia, ambas abordam algumas temáticas que são comuns às duas, tais como os impactos socioculturais do turismo ou o encontro entre turistas e anfitriões.

A temática do lazer associada à Sociologia do Turismo surge a partir do entendimento de Dumazedier (2000), pois é por meio do turismo que se podem realizar várias atividades fora do próprio habitat, proporcionando novos conhecimentos e novas descobertas.

A Sociologia do Turismo aparece aliada à Economia a partir dos estudos sociológicos do economista Jost Krippendorf (1989). Para esse autor, "[...] se não existisse o turismo, cúmplice da evasão, seria necessário construir clínicas e sanatórios, onde o ser humano se recuperasse do cansaço quotidiano" (KRIPPENDORF, 1989, p. 18).

Krippendorf (1989) sublinha que o turismo funciona como uma terapia para a sociedade, como uma válvula que de certa forma procura manter o funcionamento do mundo de todos os dias. Ele exerce um efeito estabilizador sobre o indivíduo, a sociedade e a economia. Assim é que "viajamos para viver, para sobreviver, para compensar tudo o que nos falta no cotidiano; para nos liberar da dependência social, desligar-se e refazer as energias, desfrutar da independência e da livre disposição do próprio ser" (KRIPPENDORF, 1989, p. 18).

Se a Sociologia é a ciência que estuda os fenômenos sociais e as mudanças produzidas na sociedade, então o turismo pode ser compreendido como um fenômeno social, onde a sociologia do turismo se dedica "a estudar o turismo nos seus aspetos sociais" (DIAS, 2003 apud MARUJO, 2005, p. 9). 


\subsection{TURISMO DE BASE COMUNITÁRIA (TBC)}

O Turismo de Base Comunitária foi institucionalizado pelo Ministério do Turismo a partir do edital n. 001/2008, que o define como "[...] um modelo alternativo de desenvolvimento turístico, orientado pelos princípios da economia solidária, associativismo, valorização da cultura local, e, principalmente, protagonizado pelas comunidades locais, visando à apropriação por parte dessas dos benefícios advindos da atividade turística" (BRASIL, 2008).

No Brasil, o turismo de base comunitária tem em comum as lutas sociais, com foco na conservação dos recursos naturais, base da subsistência de diversas comunidades; a luta pela terra; a luta pelo direito à memória cultural; a luta por uma educação digna. Nesse sentido, os assentamentos rurais, enquanto espaços dessa nova ruralidade nacional apontam para a criação de novas sociabilidades internas e com o exterior, além do desejo de terem, após tanta disputa política via participação nos movimentos sociais, o direito a uma vida com dignidade no campo e a conquista do reconhecimento social de sua categoria, bastante marginalizada, especialmente, pelos meios de comunicação de massa. Essas são algumas constatações alcançadas por averiguação empírica (SANSOLO, 2003; BURSZTYN, 2005; ROCHA, 2003; CORIOLANO, 2003; IRVING; AZEVEDO, 2002), dentre outros.

Coriolano (2009) analisa outros elementos acerca do surgimento do turismo comunitário, relacionando-o a uma contraposição ao chamado turismo dos resorts e dos megaempreendimentos e a uma forma de evitar que empreendedores externos dominem as comunidades. Algumas comunidades litorâneas maltratadas pelo processo de especulação imobiliária, em nome do turismo, criaram um novo eixo do turismo - o turismo alternativo ou comunitário, portanto associado à luta pela propriedade da terra litorânea, e gestado por comunidades.

Por turismo comunitário entende-se toda forma de organização empresarial sustentada na propriedade e na autogestão sustentável dos recursos patrimoniais comunitários, de acordo com as práticas de cooperação e equidade no trabalho e na distribuição dos benefícios gerados pela prestação dos serviços turísticos. Como empresa comunitária, o Turismo de Base Comunitária torna-se parte da economia social, visto que mobiliza recursos próprios e valoriza o patrimônio comum com a finalidade de gerar ocupação e meios de vida para seus membros. Não visa lucro nem a apropriação individual dos benefícios que são gerados, e sim a sua 
distribuição equitativa, através do investimento em projetos de caráter social ou de produção.

Como assegura Coriolano (2006), no Turismo de Base Comunitária, comunidades ou grupos se organizam proativamente em empreendimentos cooperativos e associativos de modo que a própria comunidade mantenha o controle efetivo da terra e das atividades econômicas e culturais associadas ao turismo. A própria comunidade assume o controle da atividade a partir do planejamento até o desenvolvimento e a gestão dos arranjos produtivos. Realizam, assim, projetos que garantem a melhoria das condições de vida local, além de se prepararem para receber visitantes e turistas de uma forma mais digna, ou seja, com melhores condições de trabalho e melhor remuneração: sem exploração humana e sem segregação social. O TBC altera, portanto, a percepção extremamente mercantilista do turismo.

Outra distinção do TBC diz respeito à sua dimensão humana e cultural, vale dizer antropológica, que estabelece uma relação dialogal e interativa entre visitantes e visitados, na perspectiva de conhecer e aprender com seus respectivos modos de vida. Nesse modo relacional, nem os anfitriões são submissos aos turistas, nem os turistas fazem dos hospedeiros meros objetos de instrumentalização consumista. Aqui, a relação visitante/visitado foge ao padrão de turismo de massa. Nessa contraposição ao turismo massificado, além da menor densidade de infraestrutura e serviços, há uma vinculação situada nos ambientes naturais e na cultura do lugar.

Trata-se de um outro modo de visita e hospitalidade. Esse turismo respeita as heranças culturais e tradições locais, podendo servir de veículo para revigorá-las e mesmo resgatá-las. Pela própria definição e seus espaços privilegiados, as motivações e o perfil do visitante também fogem ao padrão do turismo de massa. No turismo comunitário não se encontra o conforto do turismo urbano nem a oferta de bens materiais largamente consumidos pelos turistas. Muda, portanto, a percepção de quem recebe e de quem visita. Como mostra Coriolano (2009, p. 282),

[...] o turismo comunitário é aquele em que as comunidades de forma associativa organizam arranjos produtivos locais, possuindo 0 controle efetivo das terras e das atividades econômicas associadas à exploração do turismo. Nele o turista é levado a interagir com o lugar e com as famílias residentes (CORIOLANO, 2009, p. 282). 
Sansolo e Bursztyn (2009) consideram o turismo de base comunitária não como mais um segmento de mercado, mas como a possibilidade de um novo paradigma para o turismo, cujas bases se assentam nas relações de hospitalidade, da vontade de receber para intercambiar o que se tem de mais caro, que é o sítio simbólico de pertencimento (ZAOUAL, 2008), e de ser recebido, estar aberto, viajar deslocando-se do seu centro de referência para encontrar o outro.

Por outro lado, e não menos relevante, as pesquisas apontam para os receios de muitas comunidades no que diz respeito aos impactos nocivos provenientes do turismo, que se revelam nas intervenções externas e que podem significar um aumento da sua dependência no mercado, um desmembramento de seus territórios, uma aceleração na perda de sua identidade cultural, um enfraquecimento de suas instituições e coesão social. Também há a atitude hostil de uma parte da comunidade que acarreta fortes tensões internas entre os que defendem posições distintas. A percepção, as atitudes e os interesses das comunidades em relação ao turismo estão longe de serem homogêneas e harmônicas.

O tema é complexo em função do impacto gerado por uma atividade muito competitiva e crescente dentro de comunidades localizadas em regiões remotas, dedicadas às atividades tradicionais de sobrevivência, com poucas fontes alternativas de rendimento. É delicado em função do caráter ambivalente do turismo: embora isto represente uma oportunidade para melhorar o bem-estar das comunidades, não obstante, sempre traz consigo "efeitos de pacote", muitos desses irreversíveis, como as alterações nos padrões de produção e de consumo, e as ameaças à cultura local.

O turismo não somente mapeia territórios, mas cria territorialidades, pois define destinos, propõe roteiros, dando visibilidade a espaços até então "invisíveis". Além de construir espaços simbólicos, a atividade turística tece rede extensa de pequenos negócios que, por sua vez, cria sociabilidades as mais diversas. Assim, seguem pari passu os dois eixos do turismo: o globalizado e o de base comunitária, que em efervescência se contrapõem e se complementam. Esse segmento muitos governos não conseguem apreender (CORIOLANO, 2009). 


\subsection{TURISMO RURAL COMUNITÁRIO (TRC)}

As atividades turísticas rurais comunitárias alcançaram, nos últimos anos, uma grande dimensão social, envolvendo diferentes atores, demonstrando novos valores e projetando-se como tema de interesse e objeto de pesquisa dos mais variados meios, à procura do reconhecimento dos elementos representativos envolvidos, ainda passíveis de reformulações e entendimentos.

Esse segmento do turismo tem sido apontado como uma promissora alternativa de emprego e renda para as famílias agrícolas, pois o turismo rural é considerado uma atividade que dinamiza economicamente os espaços rurais, e também é visto como potencialmente sustentável, pois, além dos benefícios econômicos, pode contribuir para a conservação ambiental e para o resgate e valorização sociocultural das comunidades e famílias rurais (CANDIOTTO, 2013).

Nesse sentido, os espaços rurais já foram analisados por várias correntes de pensamentos. Algumas abordam as diferenças dicotômicas espaciais rurais e urbanas, outras analisam as inter-relações entre os diferentes espaços. Mas, na realidade, o espaço que abriga o Turismo Rural Comunitário tem seus limites nas categorias simbólicas que foram construídas, com base em representações sociais e culturais das comunidades.

São as diferentes representações, inerentes ao universo local, que caracterizam a realidade do espaço e, por isso, os "saberes e fazeres" das comunidades, além de ser a matéria-prima básica, fortalecem a representatividade das atividades rurais produtivas que encontram no turismo uma forma de valorização cultural e agregação de valor e renda.

A demanda turística tornou-se mais exigente, variada e variável. Ela tende a se focar cada vez mais sobre a qualidade e exprime as necessidades da cultura e do meio ambiente. Procura "verdadeiros sítios" que combinem a autenticidade e a profundidade do intercâmbio intercultural de uma parte e a harmonia com a natureza e a memória dos lugares visitados em outro lugar. Tais exigências parecem em total contradição com a oferta do turismo de massa que privilegia o lucro imediato e a grande escala, destruindo assim a qualidade relativa dos sítios turísticos, como expõe Zaoual (2009).

Por isso a modalidade de Turismo Rural Comunitário contrasta com os pacotes rígidos e impessoais do turismo de massa que obedecem a uma lógica 
econômica de um retorno imediato e máximo dos investimentos. Esse segmento, considera Maldonado (2009), dirige-se a pequenos grupos de viajantes em busca de experiências pessoais originais e enriquecedoras, combinando vivências culturais autênticas, permitindo desfrutar de cenários naturais e de uma remuneração adequada do trabalho comunitário. Esses e outros componentes impulsionaram o TRC na sua origem.

Essa nova concepção turística emergiu da busca pela preservação dos patrimônios culturais e naturais das comunidades indígenas na América Latina, diante das pressões do mercado ecoturístico e do turismo cultural e da aproximação de Organizações Não Governamentais ambientais, órgãos públicos, empresas privadas e bancos multilaterais em torno do novo cenário turístico que despontava (MALDONADO, 2009).

Outro componente importante na origem do TRC decorre da busca pela superação da pobreza crônica incidente na América Latina, que permanece alta, concentrada geograficamente nas áreas rurais e, especialmente, nos povos nativos. Essa situação levou milhares de comunidades a recorrer a atividades não agrícolas, alternativas para uma economia de sobrevivência: agroindústria doméstica, turismo e econegócios. Dados da Cepal - Comissão Econômica para a América Latina e o Caribe (2008) indicam que os índices de pobreza e indigência urbanas na América Latina é de $45 \%$ e de $20 \%$, respectivamente, há mais de uma década. No setor rural representaram 65\% e 39\%, respectivamente, ou seja, o triplo dos índices urbanos. Entre 2003-2008, a pobreza diminuiu em cerca de 10\%, não obstante ainda afete 182 milhões de indivíduos. As mulheres são responsáveis por $20 \%$ dessas famílias (CEPAL, 2008).

Também relevante no TRC, o papel das pequenas e microempresas na oferta turística local configura um leque de pequenos negócios, de segmentos especializados, que é um denominador comum das pequenas e microempresas.

Outra razão que se apresenta na nova dinâmica turística rural diz respeito às motivações de descanso dos trabalhadores urbanos na busca pela tranquilidade do campo como fuga do cotidiano da cidade. Segundo Graziano da Silva (2001), as novas dinâmicas em termos de geração de emprego e renda no meio rural brasileiro têm origem urbana, ou seja, são impulsionadas por demandas não agrícolas das populações urbanas, como é o caso das dinâmicas imobiliárias por residência no campo e dos serviços ligados ao lazer, como turismo rural, preservação ambiental e 
outras demandas. Nesse sentido, o meio rural deixou de ser visto apenas como um espaço para a produção agrícola e passou a ser considerado também como um espaço de lazer, moradia, turismo, dentre outras funções.

No Brasil, as experiências de turismo rural surgiram, efetivamente, a partir das últimas décadas em um contexto de grandes mudanças econômicas, políticas e sociais. As primeiras iniciativas aconteceram em Lages, Estado de Santa Catarina, na década de 1980, a partir de modelos oriundos da Europa (RODRIGUES, 2001), especialmente o modelo francês.

Mas somente a partir da década de 1990 o turismo passa a ser uma das atividades não agrícolas a agregar valor às práticas dos agricultores familiares. Schneider e Fialho (2000) destacam que em 1997 havia mais de quatro milhões de pessoas com domicílio rural no Brasil, ocupadas em outras atividades, com significativa importância para a indústria de transformação, composta sobretudo por unidades semi-industriais que processam produtos agropecuários provenientes da avicultura, suinocultura e de laticínios. São, portanto, realidades que valorizam conceitos de produção justa, de economia solidária e de relevância da cultura rural tradicional, apresentada em seus roteiros vivenciais.

A associação entre o turismo rural e a agricultura familiar despertou 0 interesse do governo federal a partir da Eco 92, quando se disseminou a retórica de desenvolvimento sustentável. O Ministério do Desenvolvimento Agrário (MDA) criou uma linha especial de crédito do Programa Nacional de Fortalecimento da Agricultura Familiar (Pronaf) - o Pronaf Turismo Rural - para implementação de projetos em propriedades familiares, como cafés coloniais, pousadas, estabelecimentos do tipo "pesque-pague" e "colha-pague", restaurantes típicos, entre outros.

Outra medida foi a parceria MDA/MTur (Ministério do Turismo) em 2004, que resultou no Programa Nacional de Turismo Rural na Agricultura Familiar (PNTRAF), objetivando

promover o desenvolvimento rural sustentável, mediante implantação e fortalecimento das atividades turísticas pelos agricultores familiares, integrado aos arranjos produtivos locais, com agregação de renda e geração de postos de trabalho no meio rural, com conseqüente melhoria das condições de vida (MDA/MTur, 2004). 
O PNTRAF aponta diversos benefícios provenientes do turismo rural para o agricultor familiar, quais sejam:

1) o aumento da renda, principalmente com a comercialização de produtos feita diretamente ao consumidor/turista;

2) a valorização da agricultura familiar, uma vez que a sua cultura torna-se o próprio atrativo turístico, com efeitos diretos no aumento da autoestima da população;

3) a dinamização da cultura rural, diante da importância para os agricultores e familiares no fortalecimento de suas identidades e autenticidade;

4) o uso racional dos recursos naturais, sua preservação, conservação e recuperação, visto que tais recursos passam a constituir atrativos turísticos;

5) a produção agroecológica, que beneficia o ambiente e contribui para a qualidade de vida dos agricultores e dos visitantes.

Porém, para tratar especificamente do turismo na agricultura familiar, foi criada a Rede de Turismo Rural na Agricultura Familiar (Rede TRAF), um grupo de articulação nacional envolvendo mais de 100 instituições, com apoio do Instituto Interamericano de Cooperação para Agricultura e o Ministério da Agricultura. Nela, o turismo rural é definido como:

A atividade turística que ocorre no âmbito da propriedade dos agricultores familiares que mantêm as atividades econômicas típicas da agricultura familiar, dispostos a valorizar, respeitar e compartilhar seu modo de vida, o patrimônio cultural e natural, ofertando produtos e serviços de qualidade e proporcionando bem-estar aos envolvidos (BRASIL, 2006, p. 5).

O caso dos assentamentos é, portanto, uma das situações possíveis desse formato turístico.

Contudo, é importante apontar as deficiências e os riscos da oferta turística comunitária que resultam, em parte, da incursão das comunidades no turismo em situações de improviso, da ausência de profissionalismo e do desconhecimento do mercado e dos instrumentos de gestão de negócios. O cenário rural apresenta, com mais evidência, déficit nos serviços básicos de saúde e infraestrutura. A oferta turística tende a ser dispersa e fragmentada com pouca diversificação dos produtos e pouca divulgação do turismo em mercados e segmentos dinâmicos.

Observa-se, também, a participação marginal ou subordinada de mulheres e suas associações na concepção e condução de projetos turísticos e, 
consequentemente, na captação de benefícios. Portanto, há que se ponderarem os riscos e os pontos fracos desse segmento, no sentido de conduzi-lo para iniciativas que operem em condições de sustentabilidade, dentro de um contexto de programas que conduzam a benefícios econômicos, sociais e ambientais para as comunidades envolvidas.

Mesmo assim, e a partir do discurso apresentado por Graziano (2002), constata-se que uma nova construção social rural está surgindo em alguns municípios brasileiros. As "novas ruralidades" aproveitam e expandem novas funções e atividades no campo, integrando e envolvendo as famílias rurais com o poder público e a iniciativa privada. Trata-se da pluriatividade ou multifuncionalidade do campo, como é classificado esse novo momento no meio rural brasileiro.

Assim, várias modalidades do turismo estão sendo criadas, adequando-as às tradições culturais e ao espaço natural das regiões. $O$ turismo alternativo, ecológico, agroturismo, entre outros, são modelos de turismo identificados como turismo rural e que se associam aos agricultores familiares. No turismo rural, o produtor passa a ser um empreendedor e prestador de serviços que, ao mesmo tempo, dedica-se à conservação do patrimônio ambiental e cultural de sua região, valor maior na oferta turística rural. O estilo de vida, os costumes e o modo de produção das famílias rurais, ou seja, a cultura do campo e o compartilhamento de tradições gastronômicas e culturais são resgatados e valorizados.

Portanto, a associação da agricultura familiar com o estilo de vida rural, os costumes, o modo de produção, a cultura do campo e a atividade turística revertemse em diversificação de trabalho e renda para a comunidade. No espaço rural, o turismo tradicional de massa está dando lugar a essa nova forma de turismo mais pessoal e acolhedora.

\subsection{PLURIATIVIDADE RURAL}

O Turismo Rural Comunitário é considerado como uma atividade não agrícola inserida na pluriatividade rural. A esse respeito, Schneider (2003) o considera como um fenômeno em que membros das famílias de agricultores moradores do meio rural escolhem exercer atividades não agrícolas, continuando a viver no campo e 
ligados, inclusive produtivamente, à agricultura e à vida no espaço rural (SHNEIDER, 2003, p. 91-92).

.Nesse sentido, o que caracteriza e define a pluriatividade é a combinação de atividades agrícolas e não agrícolas em uma mesma família ou comunidade, que tanto pode ser um recurso ao qual a família faz uso para garantir a reprodução social do grupo que the corresponde como também pode representar uma estratégia individual dos membros que constituem a unidade doméstica ou comunitária.

Segundo Anjos (2003), a pluriatividade ou a emergência de atividades não agrícolas no meio rural é um fenômeno em que famílias de agricultores tradicionalmente ocupadas com atividades estritamente agrícolas passam a desenvolver outras atividades como estratégia de complementação de renda. Essa complementação pode se dar mediante a venda da força de trabalho familiar, da prestação de serviços, ou de iniciativas internas à propriedade, como o turismo rural, o artesanato, a produção diversificada e os pequenos beneficiamentos de seus produtos.

Com a crescente integração entre campo e cidade e o fluxo de populações tipicamente urbanas para o meio rural, tal fenômeno se evidencia ainda mais. $O$ espaço rural passa a ter novas formas de desenvolvimento, com novas possibilidades de emprego em atividades de lazer caracterizadas pela crescente procura por turismo rural, ecoturismo e clubes campestres, pela crescente demanda urbana por moradias no campo e, ainda, na construção de condomínios, sítios e chácaras.

Todos esses fatores ajudam a configurar o que Graziano da Silva (2002) chama de o "novo rural", ou o processo de "urbanização do rural", no qual a tradicional oposição campo/cidade vai perdendo importância e significado. Esse mesmo autor considera que o fenômeno da emergência de atividades tipicamente urbanas no meio rural indica um processo gradativo $e$ crescente de "desidentificação" do meio rural com a agricultura.

$O$ incremento do turismo rural nas unidades de agricultura familiar é um exemplo de atividade não agrícola dentro do conceito da pluriatividade. O turismo promove a manutenção e a reprodução socioeconômica das formas tradicionais de produção familiar nessas regiões. As propriedades familiares passam a ser encaradas como sistemas produtivos e orgânicos ao qual são agregadas as novas atividades, necessariamente interligadas e integradas numa proposta concreta de 
sustentabilidade local, trazendo benefícios reais e geração de emprego e renda no campo. Além disso, a partir do interesse dos visitantes de outras regiões pelo patrimônio sociocultural local, desenvolve nos moradores um sentimento de pertencimento e de orgulho em relação às suas próprias tradições e costumes.

Desse modo, o turismo no espaço rural se associa aos agricultores familiares de maneira inovadora, valorizando e preservando o patrimônio rural. O produtor rural passa a ser um empreendedor e prestador de serviços turísticos, trabalhando diretamente na conservação do patrimônio ambiental e cultural de sua região. A relevância da atividade do turismo rural em áreas onde há a predominância da agricultura familiar pode ser constatada, na medida em que essa associação se reverte em novas oportunidades de trabalho e renda, pois, nesses casos, a economia local é ativada por meio da diversificação de novas formas de trabalho no campo. Sendo assim, as atividades não agrícolas assumem um papel relevante na composição da renda total das famílias rurais, podendo ser consideradas atividades altamente estratégicas para o crescimento socioeconômico local.

Com efeito, as novas atividades rurais estão desenvolvendo a mentalidade do empreendedorismo rural, provocando uma clara mudança no modo de encarar a pluriatividade no campo, pois, se as atividades não agrícolas não eram consideradas como fatores relevantes para o aumento da geração de renda e do nível de emprego no campo, o mesmo não se pode afirmar agora (GRAZIANO DA SILVA, 1997; DEL GROSSI; GRAZIANO DA SILVA, 1998; SCHNEIDER, 2003b).

Esse novo momento no meio rural brasileiro faz com que a pluriatividade seja uma estratégia altamente positiva, também, para a manutenção das famílias rurais no campo, de maneira digna e sustentável. Tem-se, portanto, a diminuição do fluxo migratório da população do campo rumo à cidade, por meio do aproveitamento da força de trabalho rural em atividades com maior nível de remuneração. Além disso, o incremento do turismo rural nas unidades de agricultura familiar promove a manutenção e a reprodução socioeconômica das formas tradicionais de produção familiar nessas regiões. As propriedades familiares passam a ser encaradas como sistemas produtivos e orgânicos ao qual são agregadas as novas atividades, necessariamente interligadas e integradas numa proposta concreta de sustentabilidade local, trazendo benefícios reais para a geração de emprego e renda no campo. 
Conforme pontua Schneider (2003), a afirmação da agricultura familiar no cenário social e político brasileiro está relacionada ao Pronaf (Programa Nacional de Fortalecimento da Agricultura Familiar, 1996). A partir daí, a incorporação e a afirmação da noção de agricultura familiar mostraram-se capazes de oferecer guarida a um conjunto de categorias sociais, como, por exemplo, assentados, arrendatários, parceiros, integrados às agroindústrias, entre outros, que não mais podiam ser confortavelmente identificados com as noções de pequenos produtores ou, simplesmente, de trabalhadores rurais.

Essa forma de organização do trabalho familiar vem sendo denominada pluriatividade e refere-se a situações sociais em que os indivíduos que compõem uma família com domicílio rural passam a se dedicar ao exercício de um conjunto variado de atividades econômicas e produtivas, não necessariamente ligadas à agricultura ou ao cultivo da terra, e cada vez menos executadas dentro da unidade de produção. Ao contrário do que se poderia supor, essa não é uma realidade confinada ao espaço rural de países ricos e desenvolvidos (SCHNEIDER, 2003).

Até meados da década de 1980, os termos "part-time farming" (agricultura em tempo-parcial) e "pluriactivité" (pluriatividade) eram utilizados pelos cientistas sociais quase sempre como sinônimos. No Brasil, o debate sobre a pluriatividade ainda é embrionário. Continua a ser tratado como uma curiosidade ou um fenômeno social inteiramente específico o que se denominou de "novo rural brasileiro", em alusão à emergência expressiva das atividades rurais não agrícolas e da pluriatividade no meio rural brasileiro, confirmando o entendimento de Graziano (1999).

A pluriatividade implica uma forma de gestão do trabalho doméstico que sempre inclui o trabalho agrícola, o que não quer dizer que essa atividade seja exclusiva ou mesmo a mais importante. Outras atividades podem ser assumidas com o objetivo de sustentar ou de dar suporte à unidade doméstica, ou ainda serem motivadas por considerações não relacionadas à agricultura. Nesses termos, há consenso em torno de uma das mais rigorosas definições de Fuller (1990), a qual prevê que

a pluriatividade permite reconceituar a propriedade como uma unidade de produção e reprodução, não exclusivamente baseada em atividades agrícolas. As propriedades pluriativas são unidades que alocam o trabalho em diferentes atividades, além da agricultura familiar (home-based farming) (SCHNEIDER, 2003, apud FULLER, 1990, p. 367). 
De igual modo, a pluriatividade permite separar a alocação do trabalho dos membros da família de suas atividades principais, assim como o trabalho efetivo das rendas. Muitas propriedades possuem mais fontes de renda do que locais de trabalho, obtendo diferentes tipos de remuneração. Portanto, a pluriatividade referese a uma unidade produtiva multidimensional, em que se pratica a agricultura e outras atividades, tanto dentro como fora da propriedade, pelas quais são recebidos diferentes tipos de remuneração e receitas (rendimentos, rendas em espécie e transferências (SCHNEIDER, 2003, apud FULLER, 1990, p. 367).

Assim, o fenômeno da pluriatividade pode levar a uma reorientação do modelo de desenvolvimento do meio rural brasileiro, diante da crescente preocupação mundial com o meio ambiente por intermédio de políticas direcionadas. A reorientação pode vir por meio de um modelo autossustentável, ecologicamente correto e socialmente igualitário, proporcionando a fixação e a manutenção de famílias no campo ligadas a atividades como a agricultura orgânica, agroecologia, turismo rural, ecoturismo, práticas de esporte ligadas à natureza, artesanato e pequenos beneficiamentos de alimentos. Todas essas atividades fortemente incentivadas por práticas de associativismo e de mecanismos de extensão e capacitação.

A pluriatividade nada mais é do que a diversificação das atividades rentáveis do negócio. É através dela que os membros das famílias de agricultores, que residem no meio rural, optam pelo exercício de diferentes atividades, ou ainda, optam pelo exercício de atividades não agrícolas, mantendo a moradia no campo e uma ligação, inclusive produtiva, com a agricultura e a vida no espaço rural.

Pode-se considerar que a pluriatividade e as atividades não agrícolas são mecanismos de desenvolvimento. Ambas contribuem para que a forma familiar de organização do trabalho e da produção gere novos mecanismos de sobrevivência, de garantia de sua reprodução material, e até mesmo, segundo Baumel e Basso (2004, p. 140), "a ampliação de sua importância na estrutura social”.

Essa diversificação rural não se baseia única e exclusivamente nas questões sociais, mas também na busca de novas atividades rentáveis dentro da própria empresa familiar, ou seja, diversificação do negócio da propriedade. É o exercício de mais de uma atividade, não somente como forma de agregar valor ao produto, como no caso das agroindústrias, mas também na procura de diferentes tipos de renda através de outras atividades econômicas, com a diversificação da produção primária, 
ou produção de diversas culturas, o que possibilita ao produtor uma renda provinda de varias culturas. É relevante a produção diversificada, já que ocorrendo quebra em uma produção causada por fatores climáticos, por exemplo, as outras produções podem sustentar a família, ou seja, o produtor não depende única e exclusivamente de uma renda.

Outro exemplo dessas atividades econômicas são as agroindústrias. Segundo Schneider (2003, p.174), as agroindústrias, ou atividades "para-agrícolas" consistem no beneficiamento ou processamento de produtos agrícolas in natura "[...] dentro da propriedade [...] é a chamada agregação de valor a um determinado produto [...]". Sem dúvida, essa agregação de valor ao produto é importante sob o aspecto econômico da família, porém deve-se atentar para inúmeros outros fatores que envolvem essa questão, como logística de distribuição, mercado consumidor, comercialização, tributação, preço e concorrência de outros produtos.

\subsection{MULTIFUNCIONALIDADE AGRÍCOLA}

O conceito de "multifuncionalidade" engloba desde as funções de proteção ao meio ambiente até as funções socioeconômicas que envolvem o lazer, a cultura, distribuição de emprego e renda. É possível identificar diversas novas funções da multiplicidade agrícola, dentre elas a conservação dos mananciais, dos solos, das paisagens e de alguns ecossistemas através da implantação de atividades agroflorestais, da preservação de grupos étnicos e suas identidades culturais, da promoção de atividades de lazer e turismo nos ambientes rurais, ampliação dos serviços sociais básicos na zona rural, como luz, educação e saúde, aumento da distribuição de renda, aumento do emprego, promoção da fixação do homem no campo e segurança alimentar.

Assim, a noção de multifuncionalidade se baseia nos princípios de desenvolvimento sustentável institucionalizado pela Organização das Nações Unidas (ONU) e nas constatações empíricas de que o espaço rural vem ampliando suas atividades e, portanto, se complexificando.

A propagação da ideologia do desenvolvimento sustentável conduziu à busca de "novas" atividades e formas de produzir e acumular capital que, ao menos na 
retórica, combinariam crescimento econômico, conservação ambiental e justiça social. Tais iniciativas foram fundamentais para a cristalização do conceito de multifuncionalidade. Portanto, a multifuncionalidade está vinculada à ideia de desenvolvimento sustentável e ao crescimento das atividades não agrícolas no espaço rural (pluriatividade), que por sua vez estão ligadas às novas oportunidades de acumulação capitalista a partir da emergência do regime de acumulação flexível, que transforma bens materiais e simbólicos em mercadoria.

Segundo Abramovay (1994, p. 17), a França é um dos bons exemplos da importância que se dá a tal fenômeno, com os Contratos Territoriais de Exploração (CTEs), experiência do governo socialista francês que apoia atividades como a "preservação da paisagem e patrimônio natural como também a própria vitalidade do tecido social rural".

Por ser o conceito de multifuncionalidade claramente ligado a um "espaço" ou território, ele pode ajudar nas políticas de inserção social no Brasil, como, por exemplo, a reforma agrária, num contexto mais amplo de oportunidades não ligadas estritamente à produção agrícola. Mas talvez também apareça relacionado a outras atividades vinculadas ao campo, como o turismo rural e o ecoturismo, entre outras, todas elas associadas a uma valorização ambiental e cultural da região.

No entendimento de Soares (2000, 2001), a multifuncionalidade identifica-se com as funções-chave da agricultura: contribuição à segurança alimentar; função ambiental; função econômica e função social. Para ele, o reconhecimento das múltiplas funções estratégicas que a agricultura familiar exerce para a sociedade dá respaldo às políticas públicas adequadas ao fortalecimento da agricultura familiar.

Para Carneiro e Maluf (2003, p. 19), a noção de "multifuncionalidade" rompe com $\circ$ enfoque setorial e amplia o campo das funções sociais atribuídas à agricultura, que deixa de ser entendida apenas como produtora de bens agrícolas. Ela se torna responsável pela conservação dos recursos naturais (água, solos, biodiversidade e outros), do patrimônio natural (paisagens) e pela qualidade dos alimentos.

No Brasil, algumas funções relacionadas à multifuncionalidade já eram percebidas mesmo antes da Eco 92, quais sejam: a reprodução socioeconômica das unidades familiares, apesar de uma redução significativa a partir do êxodo rural da década de 1970; e a segurança alimentar das famílias (autoconsumo) e da sociedade que é garantida no país, apesar do crescimento do agronegócio e da 
concentração fundiária. O que muda nesse contexto é a emergência da pluriatividade exercida por membros das famílias rurais, seja dentro ou fora da unidade de produção, o que significa menos dependência das atividades agropecuárias.

No entanto, é preciso atentar-se para os desmembramentos econômicos, sociais e culturais desse novo contexto agrícola e rural, no que se refere à conservação ambiental com extração e cultivo sustentáveis de alimentos e outros recursos, tendo em vista a redução das áreas de cultivo diante das exigências legais para recuperação florestal, a despeito das práticas ilegais de desmatamentos em Áreas de Preservação Ambiental e Reservas Ecológicas.

Sendo a preservação das paisagens um atributo essencial no conceito de multifuncionalidade agrícola, a prática turística poderá comprometer a preservação das paisagens, mesmo no turismo contemplativo, que implica no consumo imaterial de determinadas áreas rurais, além dos impactos à flora e fauna provenientes do acesso frequente dos visitantes. Enfim, falar de manutenção do tecido social e cultural é complicado, pois, assim como a paisagem, a cultura e a sociedade são dinâmicas, conforme referencia Carneiro (2003).

Nesse sentido, Carneiro (2003) considera que, assim como as paisagens, é preciso manter as características socioculturais que podem ser apropriadas como mercadorias, sobretudo pelo turismo e pela indústria cultural, apesar das inevitáveis mudanças no tecido sociocultural rural decorrentes da visitação turística. Seja por meio de um emprego ou ocupação no ramo do lazer e do turismo, seja pelo contato direto ou indireto com os visitantes, indivíduos da população rural acabam tendo suas territorialidades modificadas.

As implicações do uso indiferenciado de multifuncionalidade da agricultura e multifuncionalidade do agricultor são ressaltadas por Carneiro (2003), que afirma: "Se for entendido que o agricultor como ator social tem múltiplas inserções na sociedade, a possibilidade de integrar as diversas esferas do social a partir de sua atuação parece mais ampla do que se mantido o olhar centrado na agricultura - um setor da economia" (CARNEIRO; MALUF, 2003, p. 19).

De forma geral, fala-se em multifuncionalidade da agricultura, porém não é difícil confundir a multifuncionalidade da agricultura com a multifuncionalidade do agricultor, haja vista a complementaridade entre essas. A multifuncionalidade da agricultura só ocorrerá se o agricultor for valorizado como multifuncional, da mesma 
forma que o reconhecimento da multifuncionalidade da agricultura pode levar ao crescimento do número de agricultores multifuncionais.

Carneiro e Maluf (2003) parecem ver a multifuncionalidade como um elemento do agricultor, e associa a pluriatividade com a multifuncionalidade. Assim, o atual enfoque na multifuncionalidade pode justificar tanto ações de conservação ambiental e sociocultural como também ações protecionistas. As novas atividades que vão se inserindo no espaço rural (turismo rural, produção agroecológica, formação de agroindústrias, entre outras) indicam o crescimento da pluriatividade em membros das famílias rurais, e também a ampliação de um caráter multifuncional da agricultura, pois podem contribuir tanto para o reconhecimento da importância da agricultura familiar quanto para a conservação ambiental e valorização sociocultural.

Nesse sentido, a compensação dada pelo Estado ao agricultor corresponderia a um compromisso da sociedade com a multifuncionalidade da agricultura e com um ambiente mais saudável. Portanto, caberia à sociedade e ao Estado reconhecer que a agricultura familiar é, por excelência, multifuncional, e a partir daí, implementar normas e políticas públicas que levem em consideração as funções econômicas, socioculturais e ambientais dos agricultores familiares.

A efetivação da multifuncionalidade do rural e da agricultura impõe que o agricultor opte por se tornar realmente multifuncional. Assim, a multifuncionalidade do agricultor precede à da agricultura e do rural. Por conseguinte, essa postura do agricultor, através do reconhecimento das múltiplas funções da agricultura, é fundamental para concretizar/efetivar um desenvolvimento que leve em consideração as dimensões plurais que envolvem a agricultura e o espaço rural.

Assim, entendemos que na retórica, predomina a concepção de multifuncionalidade da agricultura, mas a concretização da agricultura como um setor multifuncional, que integra as dimensões ambientais, econômico-produtivas e socioculturais, depende do seu reconhecimento pelo agricultor familiar, bem como de políticas públicas para ampliar práticas multifuncionais. Acredita-se que sem políticas públicas diferenciadas que valorizem as múltiplas funções da agricultura e do agricultor e que lhe permitam desenvolver e implementar ações para além da dimensão econômico-produtiva, fica difícil exaltar a multifuncionalidade no rural brasileiro.

Todavia, considerando que aspectos históricos e conceituais da multifuncionalidade da agricultura, pode-se afirmar que a retórica desse conceito 
carrega intencionalidades implícitas que precisam ser reveladas, pois essa pode trazer implicações positivas e/ou negativas para o fortalecimento da agricultura familiar. De todo modo, e não menos importante, a multifuncionalidade pode auxiliar nas políticas de inserção social dado o seu vínculo com um "espaço" ou território. No Brasil, tem-se como exemplo a reforma agrária que, num contexto mais amplo de oportunidades não ligadas estritamente à produção agrícola, podem-se inserir outras atividades ligadas ao campo, como o turismo rural e o ecoturismo, entre outras, todas elas incorporadas à valorização ambiental e cultural da região.

\subsection{TURISMO NOS ESPAÇOS RURAIS DE ASSENTAMENTO}

Com a retórica do desenvolvimento sustentável, a partir de 1992, o turismo rural tem sido apontado como uma promissora alternativa de geração de emprego e renda, valorização da propriedade rural e dos recursos naturais e culturais das famílias agrícolas.

Além de ser visto como uma atividade que dinamiza economicamente os espaços rurais, o turismo rural também é tido como uma atividade potencialmente sustentável, complementar à produção agropecuária, que estaria beneficiando os agricultores familiares no fortalecimento da prática agrícola, com consequente elevação da autoestima da população rural. Além disso, promove a revitalização do espaço rural e a preservação do meio ambiente, dentre outras vantagens.

Coriolano (2006) atenta para a apropriação por parte do turismo de locais até então desconsiderados e excluídos do "modelo global", porém inseridos em uma dinâmica de mercado favorável a esse segmento, argumentando que 
as classes de menor poder aquisitivo dos países avançados descobrem o turismo social e as populações das regiões de expansão do capitalismo descobrem formas de captar essa demanda. Assim, há indícios de que o turismo se estenda cada vez mais para áreas nunca antes previstas como, por exemplo, favelas, terras indígenas, acampamentos dos sem-terra, lugares excluídos do modelo global, denotando uma força de inércia e de inclusão em contraposição à exclusão. Existem vários casos de espaços segregados que passaram a vender arranjos produtivos para 0 turismo, tendo surgido no Nordeste e no Norte do Brasil o chamado turismo solidário, participativo, comunitário, de inclusão, mostrando a dinâmica dessa atividade e a possibilidade de turistas para todos os segmentos e gostos. O turismo vem se expandindo pelo espaço geográfico de uma forma muito rápida, tendo o ambiente como matéria prima, reproduzindo essa contradição intrínseca à produção capitalista, referente a (in)sustentabilidade social e ambiental CORIOLANO, 2006, p. 35).

Isso nos leva a observar o que Milton Santos (1996) diz a respeito da competitividade, que hoje se apresenta como uma forte arma a favor dos atores hegemônicos do capital, e sua disseminação é uma estratégia de expansão do capitalismo globalizado que não se preocupa com o lugar e com seus habitantes.

Essas transformações no meio rural brasileiro sugerem uma série de reflexões para o seu desenvolvimento sócio-econômico-ambiental. desenvolvimento da sociedade capitalista e do turismo está atrelado ao processo de globalização, adverte Coriolano (2006). Essa sociedade tem conduzido o turismo à ocupação de espaços de movimentos sociais, visando a obtenção de lucros. Mas, apesar de a expectativa principal do turismo ser o lucro e concentrar riqueza e renda, também cria oportunidades de ganhos para os trabalhadores e os lugares mais pobres (CORIOLANO, 2006). Isto porque a participação dos camponeses/ agricultores familiares no planejamento e gestão do turismo rural na agricultura familiar possibilita que esses agricultores sejam os maiores protagonistas de seu desenvolvimento, e, também, os maiores beneficiários do referido programa.

Nesse sentido, e buscando fortalecer a autonomia individual e coletiva dessa categoria social, Candiotto (2003) faz referência ao MST do Rio Grande do Sul, que lançou o programa de turismo MSTur, cujo objetivo principal é apresentar as experiências bem-sucedidas (SANTOS et al., 2010) que esses assentamentos vêm produzindo, a partir da visibilidade alcançada junto aos estudantes, intelectuais, sindicalistas e simpatizantes do Movimento, além de demonstrar o modo de vida camponês sem encenações. Ao mesmo tempo, conscientizar os visitantes sobre a 
resistência e luta em busca da reforma agrária, o objetivo maior dos assentamentos rurais.

O Projeto de Turismo Rural do Assentamento Boa Vista em Quixadá/CE', financiado pelo Pronaf Infraestrutura, é um exemplo de assentamento coletivo e propriedade agroecológica que recebe excursões técnicas e outros tipos de visitantes. Com as práticas do turismo rural, as mulheres têm sido protagonistas no desenvolvimento dessa atividade, com grande destaque. O turismo rural é entendido pelas mulheres como uma nova opção para a complementação da renda, sem que elas tenham de sair de sua comunidade, associando as atividades domésticas e agrícolas com as atividades relacionadas ao turismo. O Projeto tem proporcionado a inclusão das mulheres em todas as atividades: domésticas (limpeza, cozinha), recepção, fornecimento de produtos beneficiados na unidade familiar e ainda participando da gestão de uma pousada.

Outro exemplo da inclusão feminina em atividades relacionadas ao turismo pode ser encontrado no Assentamento Rural Andalúcia, no município de NioaqueMS. Ali, as mulheres produzem tecelagem desde a fiação de lã e algodão, tingidos com corantes naturais extraídos do próprio espaço rural. As peças por elas confeccionadas, tais como mantas, caminhos de mesa, tapetes, bolsas, entre outras, têm excelente penetração no mercado, com resultados expressivos para a economia familiar.

\subsection{NA ÓTICA DA SUSTENTABILIDADE}

A palavra "sustentável" provém do latim "sustentare" (sustentar; defender; favorecer; apoiar; conservar; cuidar). "Sustentabilidade" aparece definida nos dicionários como a habilidade, no sentido de capacidade de sustentar ou suportar uma ou mais condições, apresentada por algo ou alguém. É uma característica ou condição de um processo ou de um sistema e que permite a sua permanência, em certo nível, por um determinado prazo. "Sustentabilidade" (ou "sustentável") é um conceito sistêmico, relacionado com a continuidade articulada dos processos econômicos, sociais e ambientais globais enquanto são viáveis. É, portanto, insustentável aquilo que não pode subsistir garantindo a satisfação das 
necessidades dos seres humanos no presente e preservando simultaneamente a biodiversidade, os ecossistemas naturais e a qualidade de vida das pessoas.

Sustentabilidade, portanto, é um termo usado para definir ações e atividades humanas que visam suprir as necessidades atuais dos seres humanos, sem comprometer o futuro das próximas gerações. Ou seja, a sustentabilidade está diretamente relacionada ao desenvolvimento econômico e material sem agredir o meio ambiente, usando os recursos naturais de forma inteligente para que eles se mantenham no futuro.

Esse termo foi usado, pela primeira vez, pela norueguesa Gro Brundtland, exprimeira ministra de seu país, em 1987. Como presidente da World Comission Enviromentand Development (Comissão Mundial sobre o Meio Ambiente e o Desenvolvimento), Brundtland publicou um livreto chamado Our common future (Nosso futuro comum), que relacionava meio ambiente com progresso. Nele, escreveu-se pela primeira vez o conceito de "sustentabilidade": "o desenvolvimento sustentável é aquele que atende às necessidades do presente sem comprometer a possibilidade de as gerações futuras atenderem a suas próprias necessidades" (Nosso futuro comum, 1991, p. 49).

A proposta não era só salvar a Terra cuidando da ecologia, mas suprir todas as necessidades de gerações sem esgotar o planeta. "Nem de longe se está pedindo a interrupção do crescimento econômico", destacou Gro, que também advertiu: "os problemas de pobreza e subdesenvolvimento só poderão ser resolvidos se tivermos uma nova era de crescimento sustentável" (GRO, 1987).

O Relatório Brundtland faz parte de uma série de iniciativas, anteriores à Agenda 21 (1992), as quais reafirmam uma visão crítica do modelo de desenvolvimento adotado pelos países industrializados e reproduzido pelas nações em desenvolvimento, e que ressaltam os riscos do uso excessivo dos recursos naturais sem considerar a capacidade de suporte dos ecossistemas. O documento aponta para a incompatibilidade entre desenvolvimento sustentável e os padrões de produção e consumo vigentes.

Realizada no Rio de Janeiro, em 1992, a Cúpula da Terra, como ficou conhecida, adotou a Agenda 21, avançando em questões ambientais ao abordar os padrões de desenvolvimento que causam danos ao meio ambiente. Elas incluem: a pobreza e a dívida externa dos países em desenvolvimento; os padrões 
insustentáveis de produção e consumo; as pressões demográficas e a estrutura da economia internacional.

$\mathrm{Na}$ concepção de Enrique Leff $(2011)^{3}$, o princípio de sustentabilidade surge no contexto da globalização como a marca de um limite e o sinal que reorienta o processo civilizatório da humanidade. A crise ambiental veio questionar a racionalidade e os paradigmas teóricos que impulsionaram e legitimaram 0 crescimento econômico, negando a natureza. A sustentabilidade ecológica aparece, assim, como um critério normativo para a reconstrução da ordem econômica, como uma condição para a sobrevivência humana e um suporte para se chegar a um desenvolvimento duradouro, questionando as próprias bases da produção.

Para Leff (2011), o conceito de sustentabilidade surge, portanto, do reconhecimento da função de suporte da natureza, condição e potencial do processo de produção. Urge perceber a verdadeira importância do equilíbrio entre o progresso, a relação de consumo com o meio ambiente, para que as futuras gerações possam usufruir do mesmo, sendo que é um direito delas e um dever nosso de proporcionar um meio ambiente saudável. Desta forma, percebe-se que o crescimento sustentado pressupõe que a economia em suas diversas faces busque um equilíbrio e uma estratégia para com o meio ambiente. São os desafios com os quais se defronta o projeto civilizatório da humanidade ao vislumbrar o próximo milênio.

Tais desafios estão contemplados nos Objetivos do Desenvolvimento do Milênio (ODM), também conhecidos como Oito jeitos de mudar o mundo, que é um conjunto de metas pactuadas pelos governos dos 191 países-membros da ONU durante a Cúpula do Milênio, em 2000. O compromisso previa um conjunto de oito macro-objetivos voltado basicamente para as áreas de saúde, renda, educação e sustentabilidade, com previsão de alcance até 2015.

A Cúpula das Nações Unidas sobre o Desenvolvimento Sustentável aprovou, em 2015, uma Declaração com 17 objetivos (Quadro 1, abaixo) e 169 metas sob as bases estabelecidas pelos Objetivos do Desenvolvimento do Milênio (ODM), que traz o título de Transformando nosso mundo: a Agenda 2030 para o

\footnotetext{
${ }^{3}$ Segundo Leff, "os princípios e objetivos do ambientalismo expressaram uma falta constitutiva das ciências. Esta falta de conhecimento é uma falta no conhecimento (...). O saber ambiental é o ponto de não conhecimento que impulsiona a produção do saber" (LEFF, 2011, p. 155).
} 
desenvolvimento sustentável. Esses objetivos e metas devem ser implementados em todos os países do mundo durante os próximos 13 anos, até 2030.

A Agenda 2030 é um plano de ação para as pessoas, o planeta e a prosperidade. Ela busca fortalecer a paz universal com mais liberdade, e reconhece que a erradicação da pobreza em todas as suas formas e dimensões, incluindo a pobreza extrema, é o maior desafio global ao desenvolvimento sustentável.

Quadro 1 - Objetivos de Desenvolvimento Sustentável (ODS)

$>$ Acabar com a pobreza em todas as suas formas, em todos os lugares.

$>$ Acabar com a fome, alcançar a segurança alimentar e melhoria da nutrição e promover a agricultura sustentável.

> Assegurar uma vida saudável e promover o bem-estar para todos, em todas as idades.

$>$ Assegurar a educação inclusiva, equitativa e de qualidade, e promover oportunidades de aprendizagem ao longo da vida para todos.

$>$ Alcançar a igualdade de gênero e empoderar todas as mulheres e meninas.

> Assegurar a disponibilidade e a gestão sustentável da água e do saneamento para todos.

> Assegurar o acesso confiável, sustentável, moderno e a preço acessível à energia para todos.

> Promover o crescimento econômico sustentado, inclusivo e sustentável, emprego pleno e produtivo e trabalho decente para todos.

$>$ Construir infraestruturas resilientes, promover a industrialização inclusiva e sustentável e fomentar a inovação.

> Reduzir a desigualdade dentro dos países e entre eles.

$>$ Tornar as cidades e os assentamentos humanos inclusivos, seguros, resilientes e sustentáveis.

$>$ Assegurar padrões de produção e de consumo sustentáveis.

$>$ Tomar medidas urgentes para combater a mudança climática e seus impactos.

> Conservação e uso sustentável dos oceanos, dos mares e dos recursos marinhos para o desenvolvimento sustentável.

> Proteger, recuperar e promover o uso sustentável dos ecossistemas terrestres, gerir de forma sustentável as florestas, combater a desertificação, deter e reverter a degradação da terra e deter a perda de biodiversidade.

> Promover sociedades pacíficas e inclusivas para o desenvolvimento sustentável, proporcionar o acesso à justiça para todos e construir instituições eficazes, responsáveis e inclusivas em todos os níveis.

Fortalecer os meios de implementação e revitalizar a parceria global para o desenvolvimento sustentável.

O Sistema ONU é formado por organizações autônomas que visam ao cumprimento dos seus objetivos. Dentre eles, registram-se as questões que dizem respeito à igualdade de gênero e empoderamento das mulheres, agricultura familiar, combate à violência, participação feminina nas políticas públicas, conforme apresentadas na Figura 1, abaixo: 
Figura 1 - Objetivos do Sistema ONU quanto às mulheres.

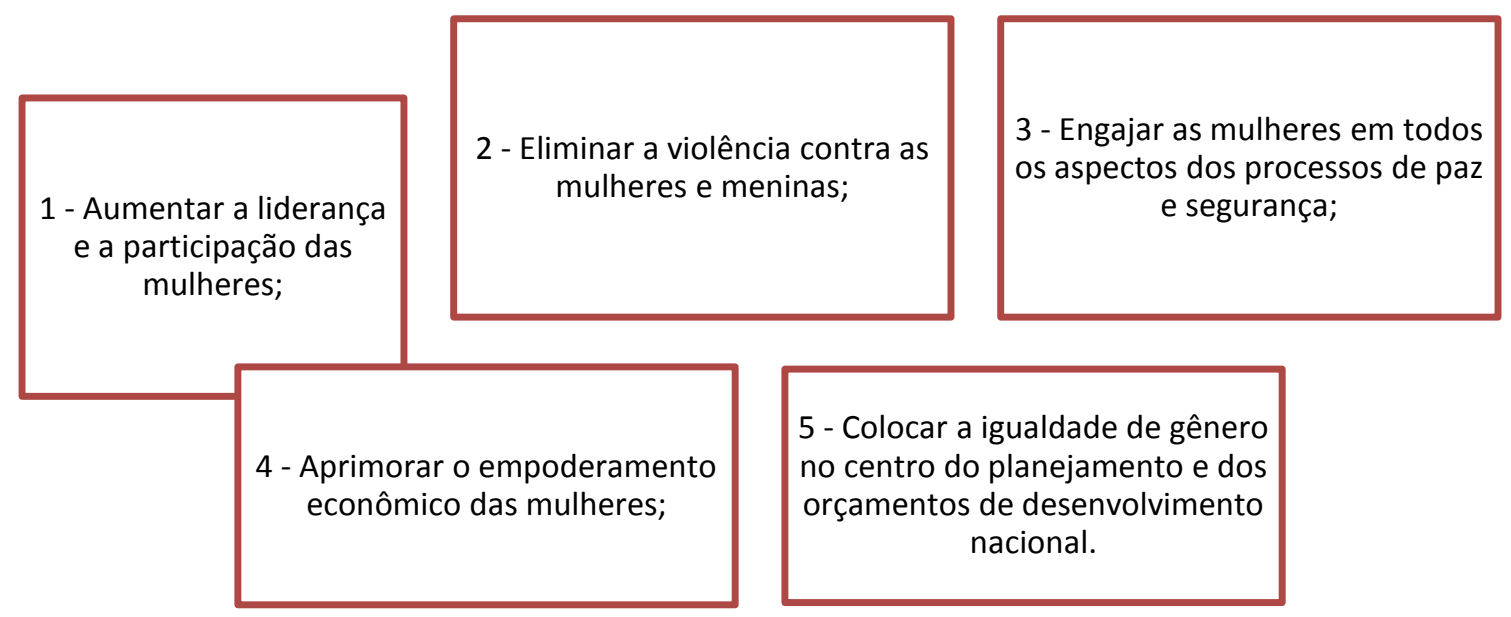

Fonte: https://nacoesunidas.org/agencia/onumulheres/. Acesso em: 12 dez. 2016.

Em relação às agências da ONU que desenvolvem projetos em voltados à agricultura e as mulheres, listamos as seguintes:

$\checkmark$ ONU Mulheres - é a nova liderança global em prol das mulheres e meninas ao redor do mundo. Defende a participação equitativa das mulheres em todos os aspectos da vida, tais como o direito a uma vida livre de discriminação, violência e pobreza, e de que a igualdade de gênero é um requisito central para se alcançar o desenvolvimento, com enfoque em cinco áreas prioritárias: aumentar a liderança e a participação das mulheres; eliminar a violência contra as mulheres e meninas; engajar as mulheres em todos os aspectos dos processos de paz e segurança; aprimorar o empoderamento econômico das mulheres; e colocar a igualdade de gênero no centro do planejamento e dos orçamentos de desenvolvimento nacional.

$\checkmark$ Organização das Nações Unidas para a Alimentação e a Agricultura (FAO) - lidera os esforços internacionais de erradicação da fome e da insegurança alimentar. A FAO tem dado atenção especial ao desenvolvimento das áreas rurais, onde vivem $70 \%$ das populações de baixa renda, que ainda passam fome. Reforça a agricultura e o desenvolvimento sustentável, como estratégia a longo prazo para 
aumentar a produção e o acesso de todos aos alimentos, ao mesmo tempo em que preserva os recursos naturais.

$\checkmark$ Fundo Internacional de Desenvolvimento Agrícola (FIDA) - atende a população rural com doações e empréstimos a juros baixos, objetivando proporcionar o empoderamento e a redução da pobreza, aumentar a segurança alimentar, melhorar a nutrição e fortalecer a resiliência.

$\checkmark$ Fundo Internacional de Desenvolvimento Agrícola - é a principal autoridade global em meio ambiente; é a agência responsável por disseminar, entre seus parceiros e a sociedade em geral, informações sobre acordos ambientais, programas, metodologias e conhecimentos, visando promover a conservação do meio ambiente e o uso eficiente de recursos no contexto do desenvolvimento sustentável. As mudanças climáticas, o manejo de ecossistemas e biodiversidade, o uso eficiente de recursos e o consumo e produção sustentáveis e a governança ambiental constituem, dentre outras, áreas temáticas de atuação dessa Agência. No Brasil, o escritório do Pnuma estabeleceu como prioridades as áreas de acesso à biodiversidade, produção e consumo sustentáveis, emissão de gases de efeito estufa, substância poluentes e turismo sustentável.

$\checkmark$ Programa das Nações Unidas para o Desenvolvimento (PNUD) desenvolve projetos em quatro áreas-chave estabelecidas no Programa de País (CPD) para o ciclo de 2017-2021, com vistas ao combate à pobreza e à desigualdade, ao fortalecimento da governança democrática, ao crescimento econômico e ao desenvolvimento humano e sustentável, os quais aparecem na Figura 2, abaixo: 
Figura 2 - Projetos-chaves do PNUD.

thit

PESSOAS: Acabar com a pobreza e a fome, em todas as suas formas e dimensões, e garantir que todos os seres humanos possam realizar o seu potencial em dignidade e igualdade, em um ambiente saudável.
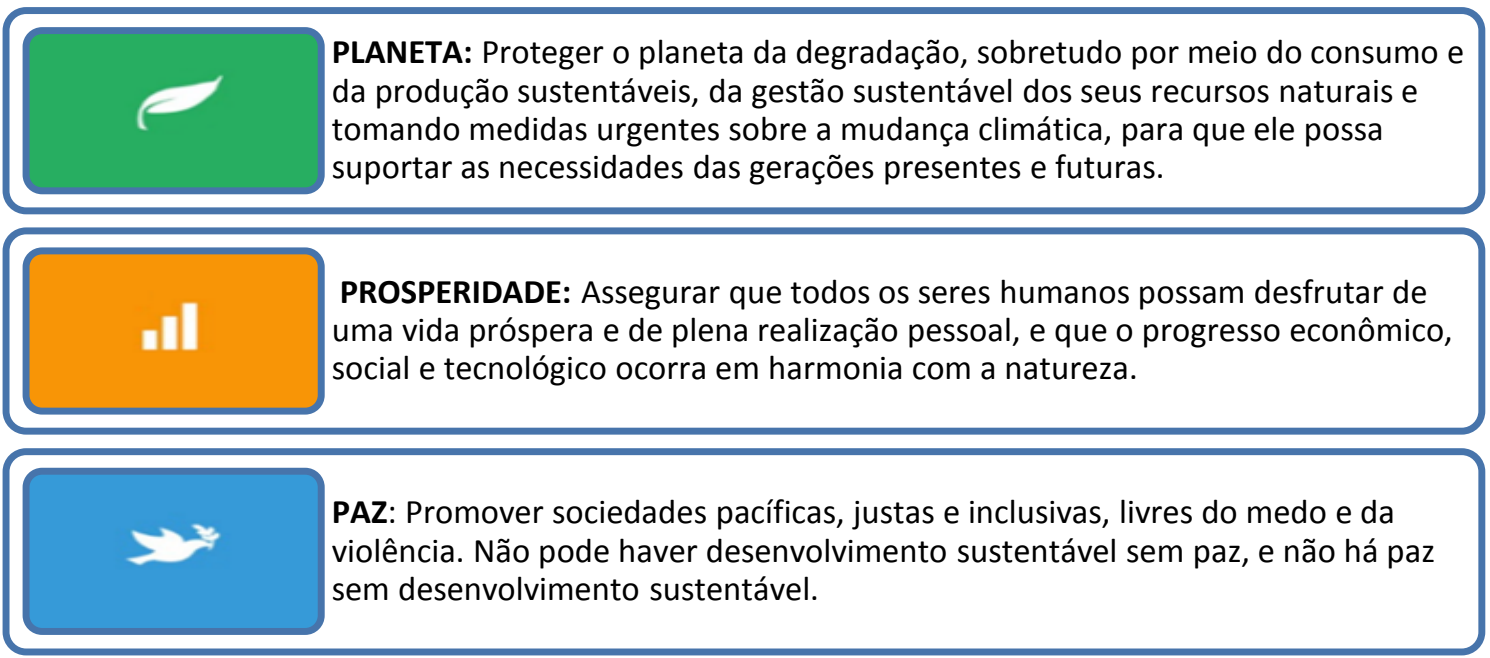

Fonte: <https://nacoesunidas.org/agencia/pnud/>. Acesso em: 12 dez. 2016.

O meio ambiente e a sustentabilidade são contemplados na Constituição Federal de 1988, no art. 225, que dispõe:

art. 225. Todos têm direito ao meio ambiente ecologicamente equilibrado, bem de uso comum do povo e essencial à sadia qualidade de vida, impondo-se ao Poder Público e à coletividade o dever de defendê-lo e preservá-lo para as presentes e futuras gerações.

Esse dispositivo constitucional apresenta um complexo conjunto de direitos à integridade do meio ambiente, típico direito de terceira geração, que acentuam o princípio da igualdade atribuído genericamente a todas as formações sociais, a própria coletividade social, uma vez que se trata de um bem de uso comum e que deve ser preservado, protegido e mantido para as presentes e futuras gerações.

Sem dúvida, os caminhos da sustentabilidade no Brasil apresentam alguns avanços nas práticas econômicas sintonizadas com os princípios da sustentabilidade, conforme atestam Bursztyn e Bursztyn (2010). Porém, há defasagens entre 0 aumento da demanda pela gestão ambiental e a oferta de instrumentos. Nesse percurso, observam os autores, há carência de recursos humanos qualificados para operar o crescente e cada vez mais complexo sistema institucional da gestão ambiental. Questões inerentes à descontinuidade administrativa, os desastres ecológicos, às limitações do Estado frente às 
sucessivas crises econômicas são alguns dos imperativos postos diante das práticas de sustentabilidade entendidas nas dimensões apontadas na literatura. A política e a gestão ambiental são objetos em construção, e os caminhos têm sido diversos, tortuosos e nem sempre estão sendo seguidos. Apresentam rotas alternativas, mas também as pedras presentes na estrada, pontuam Bursztyn e Bursztyn (2010).

$\mathrm{Na}$ visão do economista Ignacy Sachs, considerado o autor do termo "desenvolvimento sustentável", a sustentabilidade perpassa necessariamente por uma visão holística dos problemas da sociedade. É pensar além da gestão dos recursos naturais, é metamorfosear o modelo civilizatório atual, transcender o simples econômico prevendo a proteção do meio ambiente, conforme diz Sachs (2002). O desenvolvimento ambiental não pode ser dissociado das questões sociais e econômicas, que se apresenta como ecossocioeconomista, pois se entende que ecologia, sociologia e economia são conceitos integrados. Para Sachs (2002), "desenvolvimento sustentável é uma visão do desenvolvimento em que os objetivos são sempre os sociais, existe uma condicionalidade ambiental e, para que as coisas aconteçam, é preciso dar às propostas uma viabilidade econômica".

A partir do conceito científico de "ecossocioeconomia", foi desenvolvido o termo "ecodesenvolvimento", que se popularizou principalmente a partir da Rio $92 \mathrm{e}$ evoluiu para "desenvolvimento sustentável", mais usado atualmente. Ao trazer o conceito de "sustentabilidade", Sachs (2002) tomou como base seis dimensões sustentabilidade ecológica, econômica, social, espacial, cultural, psicológica -, partindo da premissa de que o desenvolvimento deve transcender o significado econômico. Posteriormente, acrescentou mais duas (2002, p. 82-89): a dimensão política nacional e a dimensão política internacional. Cada dimensão possui institutos e características próprias, devendo conceber que o desenvolvimento sustentável somente é alcançado quando todas estiverem delineadas.

Sachs propõe ampliar o conceito de desenvolvimento sustentável para um tipo de desenvolvimento que seja também includente. Segundo o autor, um desenvolvimento verdadeiramente sustentável, 
[...] obedece ao duplo imperativo ético da solidariedade com as gerações presentes e futuras, e exige a explicitação de critérios de sustentabilidade social e ambiental e de viabilidade econômica. Estritamente falando, apenas as soluções que considerem esses três elementos, isto é, que promovam o crescimento econômico com impactos positivos em termos sociais e ambientais, merecem a denominação de desenvolvimento (SACHS, 2002).

Sachs $^{4}$ considera, portanto, um desenvolvimento includente, o qual permite uma inclusão verdadeiramente justa. Nesse sentido, é preciso romper, de uma vez por todas, com paradigmas que nos levam invariavelmente a soluções excludentes. O momento, mais do que nunca, é de inclusão, em todos os níveis: social, político, ambiental, jurídico, sociológico e, fundamentalmente, econômico.

O Ministério do Meio Ambiente, por meio da Carta da Terra, de 1992, adverte que devemos "[...] assegurar que as comunidades em todos os níveis garantam os direitos humanos e as liberdades fundamentais e proporcionem a cada um a oportunidade de realizar seu pleno potencial", além de "promover a justiça econômica e social, propiciando a todos a consecução de uma subsistência significativa e segura, que seja ecologicamente responsável".

Esses fragmentos da Carta da Terra estão relacionados às questões sociais, ou seja, referem-se à distribuição de renda mais equânime, aumento da participação dos diferentes segmentos da sociedade na tomada de decisões, equidade entre sexos, grupos étnicos, sociais e religiosos, universalização do saneamento básico e do acesso à informação e aos serviços de saúde e educação, entre outros (IBGE, 2004).

Os modelos de desenvolvimento existentes afetam de maneira diferente 0 cotidiano de homens e mulheres. O padrão corrente de desenvolvimento não é nem sustentável, nem igualitário. E, conforme atesta Abramovay (1994), "para melhorar a condição do ser humano na sociedade, é importante desentranhar as estruturas de poder nas quais estamos imersos". Essa visão foi amplamente difundida entre o movimento de mulheres, que passou a incorporar nos seus programas a questão da segurança planetária em suas dimensões ambientais, sociais, econômicas, na

\footnotetext{
${ }^{4}$ Ignacy Sachs é economista. Também referido como ecossocioeconomista, por sua concepção de desenvolvimento como uma combinação de crescimento econômico, aumento igualitário do bemestar social e preservação ambiental. O termo "ecossocioeconomia" foi cunhado por Karl William Kapp, economista de origem alemã e um dos mais brilhantes inspiradores da ecologia política nos anos 1970.
} 
perspectiva de que essas questões estão subjacentes aos atuais problemas da sustentabilidade do planeta.

Mesmo com uma atuação proativa, a situação das mulheres, em nível mundial, apresenta dados alarmantes: $2 / 3$ dos analfabetos do mundo são mulheres; as mulheres dedicam a maior porcentagem de sua renda ao bem-estar dos filhos; as mulheres ganham, em média, de $2 / 3$ a $3 / 4$ menos do que os homens. Portanto, um enfoque de gênero não se refere somente às medidas utilizadas para incorporar a mulher ao processo de desenvolvimento. Questiona-se o conceito de desenvolvimento sustentável, o fim e o conteúdo do desenvolvimento, assinalando a necessidade de se buscarem novas políticas que contribuam para a mudança das estruturas de desigualdade existentes e o uso sustentável do meio ambiente. 0 desenvolvimento será sustentável e equitativo quando homens e mulheres participarem de forma mais igualitária, em todos os níveis, do processo de tomada de decisões.

O Papa Francisco, em sua Carta Encíclica Laudato Si ${ }^{5}$, traz reflexões teológicas ou filosóficas sobre a situação da humanidade e do mundo e lança um desafio de proteção à nossa casa comum na união de toda a família humana em busca de um desenvolvimento sustentável e integral. A mudança é algo desejável, mas torna-se preocupante quando se transforma em deterioração do mundo e da qualidade de vida de grande parte da humanidade, diz o Pontífice.

Diante da crescente preocupação sobre "o que está acontecendo com a nossa casa", o Papa Francisco (2015) faz uma resenha das questões que hoje nos causam inquietação e que já não se podem "esconder debaixo do tapete":

- Poluição e mudanças climáticas, considerando também os resíduos e a cultura do descarte;

- Perda da biodiversidade, cujos recursos estão sendo depredados também por causa de formas imediatistas de entender a economia e a atividade comercial e produtiva;

- Deterioração da qualidade de vida humana e degradação social, considerando os efeitos da degradação ambiental, do modelo atual de desenvolvimento e da cultura do descarte sobre a vida das pessoas;

\footnotetext{
5 Papa Francisco (2015): “Laudato si, mi Signore - Louvado sejas, meu Senhor", cantava São Francisco de Assis: "[...] a nossa casa comum se pode comparar ora a uma irmã, com quem partilhamos a existência, ora a uma boa mãe, que nos acolhe nos seus braços".
} 
- Desigualdade planetária, visto que a desigualdade não afeta apenas os indivíduos, mas países inteiros, e obriga a pensar em uma ética das relações internacionais. Há uma verdadeira "dívida ecológica" entre o Norte e o Sul; os efeitos mais graves de todas as agressões ambientais recaem sobre as pessoas mais pobres;

- A fraqueza das reações. Torna-se indispensável criar um sistema normativo que inclua limites invioláveis e assegure a proteção dos ecossistemas e não predominem os interesses dos grupos econômicos;

- A questão da água. Já se ultrapassaram os limites máximos de desperdício dos setores mais ricos da sociedade. A água potável e limpa é indispensável para a vida humana e para sustentar os ecossistemas;

- Diversidades de opiniões. A Igreja entende que se deve promover 0 debate honesto entre os cientistas, respeitando a diversidade de opiniões.

- Basta, porém, olhar a realidade com sinceridade, para ver que há uma grande deterioração da nossa casa comum, declara o Papa Francisco (2015).

A resolução aprovada pela Assembleia Geral das Nações Unidas, que adota o ano de 2017 como o Ano Internacional do Turismo Sustentável para o Desenvolvimento, não só reconhece a importância do turismo internacional no fortalecimento da interação entre os povos, com vistas à preservação da cultura, do meio ambiente, do respeito mútuo, como também impulsiona a contribuição do setor nos três pilares da sustentabilidade: econômica, social e ambiental.

\subsubsection{Desenvolvimento sustentável e a ruralidade}

Ao abordar as questões relacionadas à sustentabilidade no assentamento rural, lócus desta pesquisa, corroboramos a visão de Sachs (1993) no sentido de 
que se deve ter uma visão holística dos problemas sociais, ou seja, não focar apenas na gestão dos recursos naturais. Pensar em algo muito mais profundo, que visa uma verdadeira metamorfose do modelo civilizatório atual. $\mathrm{O}$ autor apresenta oito pilares do ecodesenvolvimento, onde estão contidos os aspectos econômicos, ambientais, sociais, culturais, territoriais, ecológicos, políticos nacionais e internacionais, já abordados anteriormente nesta pesquisa.

É importante verificar que esses conceitos podem ser aplicados tanto de maneira macro - para um país ou para o próprio planeta - quanto micro - sua casa ou uma pequena vila agrária. Assim, as questões associadas ao desenvolvimento rural passam a ganhar uma maior preocupação ecológica e social, conciliada em combater os desequilíbrios entre espaços centrais e periféricos, criando-se, assim, um modelo de desenvolvimento a partir do local (FIGUEIREDO, 2003).

O conceito social da sustentabilidade se identifica ao capital humano da comunidade do assentamento, no que se refere aos aspectos como o bem-estar dos trabalhadores rurais, a um ambiente de trabalho seguro e adequado, pensando na saúde do trabalhador e sua família, em especial nas mulheres agricultoras. Além disso, uma remuneração justa deve thes proporcionar empoderamento e visibilidade social. A meta, portanto, é construir uma civilização com maior equidade na distribuição de renda e de bens, de modo a reduzir o abismo entre os padrões de vida dos ricos e dos pobres, diz Sachs (1993). Nesse item social estão contidos também problemas gerais da sociedade, como educação, violência e até o lazer.

O pilar ambiental ou ecológico refere-se ao capital natural da localidade ou sociedade, que pode ser definido como: utilizar os recursos de hoje pensando no dia de amanhã. Ele surgiu da preocupação em adotar práticas que não agridam tanto o meio ambiente e mantenham a qualidade de vida. Consiste na manutenção das funções e componentes do ecossistema, de modo sustentável, buscando a aquisição de medidas que sejam realistas para os setores das atividades humanas. A ideia é conseguir o desenvolvimento em todos os campos, sem que, para isso, seja necessário agredir o meio ambiente. Pela sustentabilidade se torna possível a preservação das condições ecológicas, que garante a disponibilidade de alimentos para as futuras gerações. Para viabilizar a atividade rural, o setor agropecuário deve investir em práticas sustentáveis de produção, como a rotação de culturas, adubação verde, além do reflorestamento, que protege os mananciais e as nascentes dos rios - práticas essas constatadas durante a pesquisa de campo 
realizada por esta pesquisadora no assentamento rural de Chapadinha-DF, o que será abordado nos próximos capítulos.

Percebe-se, portanto, que as propriedades agrícolas geridas pelas famílias do assentamento rural, objeto desta pesquisa são, portanto, agentes essenciais para 0 desenvolvimento sustentável e para a erradicação da insegurança alimentar. É crucial, assim, aumentar sua produtividade, diversificar os meios de subsistência e estimular essas práticas sustentáveis. A segurança alimentar e a sustentabilidade são reconhecidas como a capacidade de promover a satisfação das necessidades alimentares da população, sem que haja sacrifício dos recursos naturais (água, terra, ar e matas).

No entendimento de Sachs (1993), o pilar econômico torna-se possível através da alocação e do gerenciamento mais eficiente dos recursos e de um fluxo constante de investimentos públicos e privados. Uma condição importante é a de ultrapassar as configurações externas negativas resultantes do ônus do serviço da dívida e da saída líquida de recursos financeiros do sul, dos termos de troca desfavoráveis, das barreiras protecionistas ainda existentes no Norte e do acesso limitado à ciência e à tecnologia. A eficiência econômica deve ser avaliada em termos macrossociais, e não apenas mediante o critério da rentabilidade empresarial de caráter microeconômico.

Outros pilares são apontados com aspectos mais subjetivos para serem trabalhados junto à questão da sustentabilidade. Podemos analisar as questões políticas, culturais e territoriais, porém, aceitando a premissa de que tudo está interligado, eles são importantes para qualquer tipo de análise do tripé. Segundo Sachs, as dimensões da sustentabilidade são assim apresentadas:

> Ecológica: preservação dos recursos naturais na produção de recursos renováveis e na limitação de uso dos recursos não renováveis; limitação do consumo de combustíveis fósseis e de outros recursos esgotáveis ou ambientalmente prejudiciais, substituindo-os por recursos renováveis e inofensivos; redução do volume de resíduos e de poluição, por meio de conservação e reciclagem; autolimitação do consumo material; utilização de tecnologias limpas; definição de regras.

> Econômica: eficácia econômica avaliada em termos macrossociais e não apenas na lucratividade empresarial, desenvolvimento econômico intersetorial 
equilibrado; capacidade de modernização contínua dos instrumentos de produção; razoável nível de autonomia na pesquisa científica e tecnológica; inserção soberana na economia internacional.

> Social: abrange a necessidade de recursos materiais e não materiais, objetivando maior equidade na distribuição da renda, de modo a melhorar substancialmente os direitos e as condições da população, reduzindo-se o índice de $\mathrm{GINI}^{2}$, ampliando-se a homogeneidade social; a possibilidade de um emprego que assegure qualidade de vida e igualdade no acesso aos recursos e serviços sociais.

- Espacial ou territorial: busca de equilíbrio na configuração rural-urbana e melhor distribuição territorial dos assentamentos humanos e atividades econômicas; melhorias no ambiente urbano; superação das disparidades inter-regionais e elaboração de estratégias ambientalmente seguras para áreas ecologicamente frágeis a fim de garantir a conservação da biodiversidade e do ecodesenvolvimento.

$>$ Cultural: respeito à cultura de cada local; garantindo continuidade e equilíbrio entre a tradição e a inovação.

> Política no âmbito nacional: baseia-se na democracia, apropriação universal dos direitos humanos; desenvolvimento da capacidade do Estado para implementar o projeto nacional em parceria com empreendedores e em coesão social; e

> Política no aspecto internacional: tem sua eficácia na prevenção de guerras, na garantia da paz e na promoção da cooperação internacional e na aplicação do princípio da precaução na gestão do meio ambiente e dos recursos naturais; prevenção da biodiversidade e da diversidade cultural; gestão do patrimônio global como herança da humanidade; cooperação científica e tecnológica internacional.

A dimensão econômica da sustentabilidade encontra em Paul Singer o conceito de economia solidária como "a única alternativa ao capitalismo não porque é mais eficaz economicamente que a capitalista, mas sim porque ela é solidária e precisamos da solidariedade para sermos felizes e vivermos em paz" (WEISSHEIMER, 2015). Ele afirma que as pessoas estão cansadas desse modo de vida no qual têm que competir o tempo todo, sem parar. Por isso, o essencial na 
visão da economia solidária está na segunda parte da expressão: a solidariedade. $\mathrm{O}$ mundo, segundo ele, é mais do que nunca capitalista. O capitalismo fomenta a ideia da concorrência em praticamente todos os níveis da vida humana, como se fosse a única motivação capaz de fazer as pessoas fazerem o que devem fazer.

Nesse sentido, Paul Singer (2015) apresenta um conceito que, apesar da resistência dos mais ortodoxos, começa a penetrar de modo mais acentuado o campo da economia: o da felicidade. "Não é que a economia solidária seja tão eficiente, mas sim que ela nos deixa mais felizes, sem precisar competir o tempo todo", afirmou ainda Singer, o qual citou uma recente pesquisa apontando o índice da Felicidade Interna Bruta (FIB), desenvolvido no Butão.

O FIB nasceu em 1972, elaborado pelo rei butanês Jigme Singya Wangchuck. Com o apoio do Programa das Nações Unidas para o Desenvolvimento (PNUD), o reino do Butão começou a colocar esse conceito em prática, atraindo a atenção do resto do mundo com uma fórmula para medir o progresso de uma nação. Segundo esse conceito, o cálculo da riqueza de um país deve considerar outros aspectos além do desenvolvimento econômico, como a conservação do meio ambiente e a qualidade da vida das pessoas. Butão se tornará, antes de 2020, o primeiro país do mundo a produzir todos os seus alimentos com práticas de agricultura ecológica. A partir dessa data, o uso de agrotóxicos estará proibido lá.

A noção de sustentabilidade, conforme apontam os autores Bursztyn e Bursztyn (2012), aparece como apelo à razão e como inspiração para uma mudança de rumos, de modos de relação com a natureza, de forma a alcançar equilíbrio entre a busca do bem-estar no presente e o respeito às próprias condições que assegurem a possibilidade de bem-estar às futuras gerações. Constituem vetores necessários à construção da base institucional e dos mecanismos de regulação das práticas humanas, na busca da razão perdida e da inclusão do habitat (oikos) na lógica (logia) de organização (nomia) do progresso humano. 


\section{QUESTÕES DE GÊNERO}

\subsection{GÊNERO E SUAS DIMENSÕES SOCIAIS}

O conceito de "gênero" é aberto, afirma Saffioti (2004). "Gênero" diz respeito a uma categoria histórica, cuja investigação tem demandado muito investimento intelectual.

Enquanto categoria histórica, o gênero pode ser concebido em várias instâncias: como aparelho semiótico, de acordo com Lauretis (1987); como símbolos culturais evocadores de representações, conceitos normativos como grade de interpretação de significados, organizações e instituições sociais, identidade subjetiva, a partir de Scott (1988); como, numa certa instância, uma gramática sexual, regulando não apenas relações homem-mulher, mas também relações mulher-mulher e relações homem-homem (SAFFIOTI; ALMEIDA, 1995).

O gênero é a construção social do masculino e do feminino, diz Saffioti (2004). Já Scott (1995) entende o gênero como um saber sobre as diferenças sexuais. E havendo uma relação inseparável entre saber e poder, gênero estaria imbricado a relações de poder, sendo, nas suas palavras, uma primeira forma de dar sentido a essas relações.

Tem-se, portanto, que embora o conceito de gênero tenha adquirido força e destaque enquanto instrumento de análise das condições das mulheres, ele não deve ser utilizado como sinônimo de "mulher". O conceito é usado tanto para distinguir e descrever as categorias "mulher" e "homem", como para examinar as relações estabelecidas entre elas e eles.

É de se destacar, também, que a emergência do conceito de "gênero" e sua utilização estão fortemente impregnadas de uma dimensão política, tanto no que diz respeito a suas origens, quanto aos seus propósitos. Ele ganha força a partir do movimento feminista, cujas principais propostas estão voltadas às mudanças nas relações de poder no âmbito público e no privado, procurando abolir qualquer forma de dominação-exploração no conjunto das relações sociais. 


\subsection{ECOFEMINISMO}

O Ecofeminismo deriva da combinação das palavras "ecologia" e "feminismo" e estabelece a intrínseca conexão entre ambos. "O movimento Ecofeminista traz a relação estreita existente entre a exploração e a submissão da natureza, das mulheres e dos povos estrangeiros pelo poder patriarcal” (MIES/SHIVA ${ }^{6}$, 1995, p. 23) e tem como base a teoria de que a opressão das mulheres e a opressão da natureza estão fundamentalmente ligadas. $\mathrm{Na}$ literatura, o Ecofeminismo é normalmente descrito como a crença de que o ambientalismo e o feminismo estão conectados, bem como a discriminação e a opressão baseada em gênero, raça e classe estão diretamente relacionadas à exploração e à destruição do ambiente. Questões como a poluição da água, o desflorestamento, a acumulação de lixo tóxico, o desenvolvimento agrícola e sustentabilidade, os direitos dos animais e a política de armas nucleares também são levantadas pelo Movimento Ecofeminista.

Diversos movimentos sociais de mulheres, pacifistas e ambientais deram origem ao Ecofeminismo, que interliga meio ambiente e educação ambiental, ambientalismo e feminismo. Mais especificamente, o termo "Ecofeminismo" surgiu na França em 1974, por intermédio da feminista Françoise d'Eaubonne, que escreveu Le feminisme ou lamort ( $O$ feminismo ou a morte), a partir das preocupações com o rápido e excessivo crescimento demográfico, com a degradação do meio ambiente natural e com a dominação sofrida pelas mulheres, considerados como efeitos da sociedade patriarcal, e visualizando-se a mulher como o agente privilegiado que possibilitaria a proteção do ecossistema.

A indiana Vandana Shiva, uma das principais precursoras do Ecofeminismo participou do Movimento Chipko na Índia, em 1974, quando um grupo de cerca de trinta mulheres do norte da Índia se uniu para salvar mais de $25.900 \mathrm{~km}^{2}$ de bacia hidrográfica da floresta. O desflorestamento nas florestas do Himalaia causou deslizamentos de terras, inundações e grave erosão de solo, e forçou as mulheres da aldeia a subirem ainda mais as montanhas para conseguir combustível. Agora

\footnotetext{
${ }^{6}$ Vandana Shiva é física, ecofeminista e ativista ambiental da Índia. Uma das líderes do International Forum on Globalization, Shiva ganhou o Right Livelihood Award em 1993, considerado uma versão alternativa do Prêmio Nobel da Paz. É diretora da Research Foundation for Science, Technology, and Ecology, em Nova Delhi, segundo ela "um nome muito longo para um objetivo muito humilde, que é o de colocar a pesquisa efetivamente a serviço dos movimentos populares e rurais, e não apenas fazer de conta que estamos ajudando-os".
} 
conhecido como o Movimento Chipko, palavra hindi que significa "agarrar", o nome refletiu a prática das manifestantes de colocarem os braços em volta dos troncos das árvores marcadas para derrubada e se recusarem a sair dali. Essa prática e esse termo se tornaram populares em outras áreas do mundo e eram popularmente chamados de "abraço na árvore". Shiva devota sua vida na luta contra a exploração Industrial da Ásia, América do Sul e África, e diz: "Para mim, a ecologia e o feminismo têm sido inseparáveis". É uma bioguerreira. Escreveu o livro Staying alive: women, ecology and development, em 1988, e outros importantes textos, a exemplo do livro Ecofeminismo, com Maria Mies. Shiva lidera também a Research Foundation for Science, Technology and Ecology (RFSTE), que trabalha com pesquisas sobre sustentabilidade ecológica, chamada de Navdany (Novas Sementes). Segundo Shiva, "[...] o patriarcado capitalista dominante é uma ideologia baseada no medo e na insegurança [...]".

Durante a década seguinte, o Movimento Chipko alastrou-se por todo o subcontinente. Em 1977, iniciou-se o Movimento Green Belt sob a liderança da militante ecologista Dra. Wangari Muta Maathai. Nascida no Quênia, foi a primeira mulher africana e primeira ambientalista a ganhar o Prêmio Nobel da Paz (2004) pela sua contribuição para o desenvolvimento sustentável, a democracia e a paz.

Enquanto servia ao Conselho Nacional de Mulheres em 1976, Maathai ${ }^{7}$ introduziu a ideia de plantar árvores ('Why not plant trees?') para conservar o ambiente e melhorar a qualidade de vida da comunidade. Conforme foi aumentando o interesse das pessoas, ampliou seu esforço local de plantio de árvores para uma organização da sociedade civil que difundiu para outros países africanos e finalmente se tornou o Movimento Green Belt. Ajudou as mulheres a plantarem mais de 30 milhões de árvores nas áreas rurais de suas comunidades e nos terrenos das escolas. Maathai disse que o movimento era sobre "inspirar as pessoas a assumir responsabilidades sobre o ambiente, o sistema que as governa, suas vidas e seu futuro". Promovendo a biodiversidade, a conservação do ambiente, a melhoria da qualidade de vida e, ao mesmo tempo, dando oportunidade de trabalho às mulheres, declarou que "lançamos as sementes da paz, para o presente e para o futuro".

Wangari Maathai foi, também, a primeira mulher na África Central e África Oriental a receber a graduação de Doutorado. Foi professora na Universidade de

\footnotetext{
${ }^{7}$ Wangari Muta Maathai foi uma professora e ativista política do meio-ambiente do Quênia. Foi a primeira mulher africana a receber o Prêmio Nobel da Paz.
} 
Nairobi; sofreu perseguição política com detenção, nos anos 1970; foi deputada ecologista no parlamento queniano; e vice-Ministra do Ambiente e Recursos Naturais.

O movimento Love Canal se deu a partir de uma preocupação da dona de casa Lois Gibbs com as doenças crônicas inexplicáveis apresentadas em seus filhos e nos moradores da cidade do Niagara Fall, no Estado de Nova lorque. Por meio de pesquisas e do ativismo dos residentes, foi descoberto que a vizinhança estava sob toneladas de dejetos químicos, tendo em vista que, no período de 1920 a 1953, a área onde fora construída uma escola pelo governo havia sido utilizada como depósito de resíduos químicos do Exército americano e mais nove grandes empresas do ramo.

Gibbs se tornou ativista em 1978 e começou a trabalhar em benefício de sua vizinhança num esforço para investigar as preocupações de saúde da área. Para tanto, criou a associação de moradores e protocolou documentos junto aos funcionários públicos da cidade, reclamando dos odores estranhos e da aparência de substâncias não identificáveis. Em agosto do mesmo ano, a Secretária de Estado da Saúde de Nova York autorizou o fechamento da Escola, a evacuação imediata de mulheres grávidas e crianças menores de dois anos do local, e recomendou aos moradores que não se alimentassem do que era colhido de suas hortas e não entrassem em seus porões ou, caso fosse necessário, passassem o mínimo de tempo. A pesquisa sobre a saúde dos moradores constatou um aumento de abortos, natimortos, crises nervosas, hiperatividade, epilepsia e distúrbios no trato urinário. Foram identificados mais de 82 tipos de compostos químicos, dez dos quais considerados potencialmente cancerígenos.

Rachel Carson escreveu em 1962 o livro Silent Spring (Primavera silenciosa) inspirada na luta em defesa da ecologia. Ela fez despertar a consciência da sociedade sobre o movimento ecológico e faz critica ao uso de pesticidas sintéticos e seus potenciais efeitos negativos de longo prazo. Donella Meadows figurava entre os autores do influente relatório The limits to growth (Os limites do crescimento), publicado em 1972. Petra Kelly era uma figura emblemática dos movimentos ecologistas na Alemanha. No Reino Unido, um grupo denominado Women for Life on Earth (As mulheres em prol da vida na Terra) organizou um "acampamento da paz" na base aérea de Greenham Common para protestar contra a disseminação de mísseis de cruzeiro pela Organização do Tratado do Atlântico Norte (Otan). A 
filósofa australiana Val Plumwood, outra importante ativista, explorava uma nova ideia de ética no meio ambiente e, em 1992, escreveu o livro Feminism and the mastery of nature.

$\mathrm{Na}$ década de 1970, Plumwood se envolveu em uma radical critica do tradicional conceito ocidental de natureza segundo a qual humanos importavam, e a natureza não era moralmente significante. A ativista criticava o antropocentrismo, ou seja, a dominação humana sobre a natureza, e afirmava que as lutas sociais e ambientais eram indissociáveis.

As correntes ecofeministas foram difundidas e receberam maior visibilidade social no Brasil e no mundo com a realização da ECO-92 (CASTRO; ABRAMOVAY, 1997, apud SILIPRANDI), que contou com a presença de muitas organizações que fizeram parte da coordenação do Planeta Fêmea, na propagação de uma visão feminina do mundo. Defenderam os países do Hemisfério Sul, cuja pobreza teria sido gerada pelos países do Norte. Destacaram a necessidade de ações locais para recuperar o meio ambiente e foram relacionados problemas de saúde. A mobilização das mulheres a partir da ECO-92 consolidou uma visão de que feminismo e ecologia estavam profundamente ligados, uma vez que ambos propunham mudanças profundas na ordem natural, baseadas na justiça social e degradação ambiental, além de lutar pelos direitos sexuais e reprodutivos femininos.

O pensamento ecofeminista, visto pelo ângulo econômico, aponta que a mulher e a natureza são tidas como recursos ilimitados que proporcionam a acumulação do capital. No enfoque político, a mulher é identificada com a natureza e o homem com a cultura, perpetuando, assim, a hierarquização do homem e cultura para legitimar a opressão da mulher e da natureza. Do ponto de vista das políticas científicas e tecnológicas do desenvolvimento econômico moderno, não há neutralidade de gênero, além de formar uma visão que exclui o feminino do campo do conhecimento "cientifico". Por sua vez, o ecofeminismo pode ser dividido em três tendências:

1) O Ecofeminismo clássico denuncia a naturalização da mulher como um dos mecanismos de legitimação do patriarcado. Segundo o ecofeminismo clássico, a obsessão dos homens pelo poder tem levado o mundo a guerras suicidas, ao envenenamento e à destruição do planeta. Nesse contexto, a ética feminina de proteção dos seres vivos se opõe à essência agressiva masculina, e é fundamentada através das características femininas igualitárias e por atitudes 
maternais que acabam pré-dispondo as mulheres ao pacifismo e à conservação da natureza, enquanto os homens seriam naturalmente predispostos à competição e à destruição;

2) O Ecofeminismo espiritualista do Terceiro Mundo recebeu influência dos princípios religiosos de Ghandi, na Ásia, e da Teologia da Libertação, na América Latina. Vinculado às tendências místicas do Ecofeminismo primordial, a teoria feminista de Vandana Shiva recorre à cosmologia hindu para resgatar o "principio feminino", trazido à tona em 1988, como principio ecológico e de conservação como uma ligação íntima entre os princípios masculino e feminino, com seus distintos atributos, presentes em todos os seres vivos. Essa autora critica o desenvolvimento atual, tendo-o como enraizado no patriarcalismo da homogeneidade, da centralização e da dominação ocidental, além de ser fonte inesgotável de violência contra a mulher e a natureza. Na América Latina, a Teologia da Libertação inicia a elaboração de um pensamento teológico ecofeminista. Contudo, o ecofeminismo latino-americano foca-se, especialmente, nas mulheres pobres e na defesa dos indígenas, ambos considerados as principais vítimas da destruição da natureza. Shiva e Carbonell corroboram com Gebara quanto ao conceito da teologia ecofeminista:

\footnotetext{
Uma postura política crítica, que tem a ver com a luta antirracista, antissexista e antielitista. As mulheres, as crianças, os povos de origem africana e indígena, são as primeiras vítimas e, portanto, os primeiros a serem excluídos dos bens produzidos pela terra. São eles também os que ocupam os lugares mais ameaçados do ecossistema. São eles que vivem mais fortemente em seu corpo o perigo de morte que o desequilíbrio ecológico os impõe (GEBARA 1997. p. 7).
}

3) Ecofeminismo construtivista defende a relação da maioria das mulheres com a natureza como sendo dissociada das características próprias do sexo feminino, mas originária de suas responsabilidades de gênero na economia familiar, criadas através da divisão social do trabalho, da distribuição do poder e da propriedade. Sua consciência ecológica decorre da interação compulsória com o meio ambiente, que adquire ao suprir necessidades diárias, independente das características afetivas ou cognitivas próprias de seu sexo (SILIPRANDI, 2006).

A filósofa e teóloga Lucia R. Carbonel (2014) traz em seu ensaio Ecofeminismos y teologías de la liberación, reflexões a respeito da necessidade de "[...] uma nova sabedoria, uma ecosofia transcultural e transreligiosa", que nos possibilite reconhecer, "com humildade", que habitamos a mesma terra, somos 
interdependentes uns com os outros e necessitamos de reconciliação com o nosso corpo e com a natureza. Propõe-se "uma nova arte de viver baseada na capacidade de reconhecer os limites e o respeito aos ciclos naturais de regeneração do nosso corpo e de nossos recursos psíquicos, dos outros e da Terra" (CARBONEL, 2014, p. 108).

Em suma, a ecosofia compreende uma sabedoria ética, espiritual e ecológica, com capacidade de melhorar a diversidade da vida, das culturas e das pessoas, que contribua para uma harmonia e justiça entre os seres humanos, entre os sexos e a natureza, de acordo com Carbonel (2014).

Ação estratégica das mulheres do campo por um país mais justo e igualitário se faz presente, aqui no Brasil, na Marcha das Margaridas (Figura 3, abaixo). É a marcha das mulheres trabalhadoras rurais ${ }^{8}$ que recebeu esse nome em homenagem à ex-líder sindical, Margarida Maria Alves. Ela foi assassinada em 1983, na porta de sua casa, por latifundiários do Grupo Várzea, na cidade de Alagoa Grande, Paraíba.

Margarida se tornou um símbolo de força, de garra, de coragem, de resistência e luta. Um exemplo e um estímulo com grande força mobilizadora. Cada mulher trabalhadora rural se inspira em Margarida Alves para resistir, lutar contra as formas de discriminação e violência no campo, qualificar, mobilizar e participar das lutas por igualdade de gênero, por justiça e paz no campo.

\footnotetext{
${ }^{8}$ Margarida Maria Alves era Presidente do Sindicato dos Trabalhadores Rurais de Alagoa Grande, na Paraíba, e fundadora do Centro de Educação e Cultura do Trabalhador Rural. Ela obteve grande destaque na região por incentivar os trabalhadores rurais a buscarem na Justiça a garantia dos seus direitos protegidos pela legislação trabalhista. Promovia campanhas de conscientização com grande repercussão junto aos trabalhadores rurais que, assistidos pelo Sindicato, moviam ações na Justiça do Trabalho, para o cumprimento dos direitos trabalhistas, como carteira de trabalho assinada, 13은 salário e férias.
} 
Figura 3 - Mulheres na Marcha das Margaridas, em Brasília-DF.

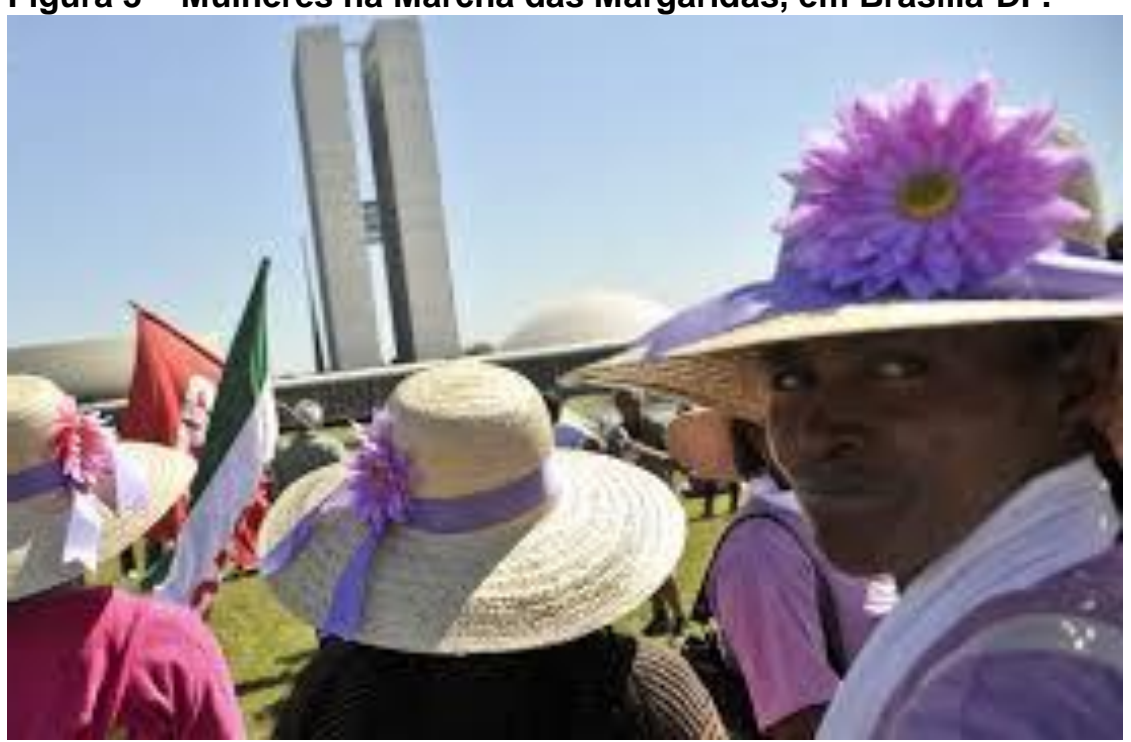

Fonte: www.google.com.br/search?q=marcha+das+margaridas+2017. Acesso em: 02 fev. 2017.

A plataforma política e a pauta de reivindicações dessas mulheres focalizam questões estruturais e conjunturais e aquelas específicas das trabalhadoras do campo e da floresta. Todas buscam a superação da pobreza e da violência e o desenvolvimento sustentável com igualdade para as mulheres. Esse Movimento já alcançou várias conquistas, algumas das quais se descrevem abaixo:

$\checkmark$ Criação do Programa Nacional de Documentação da Mulher Trabalhadora Rural (PNDMTR), com ações educativas e unidades móveis em alguns Estados;

$\checkmark$ Titulação Conjunta Obrigatória - Edição da Portaria 981 de 02 de outubro de 2003;

$\checkmark$ Normas para efetivar o direito das trabalhadoras rurais ao Programa Nacional de Reforma Agrária; dentre elas, a prioridade às mulheres chefes de família (IN 38 de 13 de março de 2007);

$\checkmark$ Formação do Grupo de Trabalho (GT) sobre Gênero e Crédito e a Criação do Pronaf Mulher;

$\checkmark$ Criação do "crédito instalação" para mulheres assentadas;

$\checkmark$ Criação do Programa de Apoio à Organização Produtiva das Mulheres;

$\checkmark$ Apoio para a realização de feiras para comercialização dos produtos dos grupos de mulheres;

$\checkmark$ Representação na Comissão Tripartite de Igualdade de Oportunidades, do Ministério do Trabalho. 
As conquistas se expandem nos setores de saúde, educação e enfrentamento à violência para o atendimento das mulheres rurais. Porém, o vazio quanto a gênero e meio ambiente nas agendas oficiais ainda é inquietante.

As mulheres do Assentamento Rural Chapadinha-DF marcham com "as Margaridas" por desenvolvimento sustentável com justiça, autonomia, igualdade e liberdade. Elas denunciam e protestam contra a fome, a pobreza e todas as formas de violência, exploração, discriminação e dominação e avançam na construção da igualdade para as mulheres, atuando para que sejam protagonistas de um novo processo de desenvolvimento rural voltado para a sustentabilidade da vida humana e do meio ambiente. E lutam para dar visibilidade e reconhecimento à suas contribuições econômicas, política e social.

Esta pesquisadora entende que a abordagem de gênero na questão ambiental pode evidenciar elementos fundamentais para a construção de um desenvolvimento sustentável com equidade. Os vínculos entre feminismo e ecologia se consolidam a partir da mobilização das mulheres, uma vez que ambos propõem profundas mudanças na ordem natural, baseadas na justiça social. Esse vínculo histórico é lembrado por Ecofeministas sob diversos ângulos: da opressão das mulheres e a opressão da natureza, pontuado por MIES/SHIVA (1995); a conservação do meio ambiente e a melhoria da qualidade de vida, introduzido por Maathai; as preocupações com a contaminação do meio ambiente, a partir de Gibbs; as críticas ao uso de pesticidas sintéticos, feitas por Rachel Carson; os movimentos ecologistas na Alemanha conduzidos por Petra Kelly, dentre outros fundamentos igualmente importantes.

As concepções ecofeministas alinhadas com os movimentos sociais empreendidos pelas mulheres da cidade e do campo têm confirmado que as mulheres não estão vendo o planeta da janela da casa. Elas estão do lado de fora, com os pés na terra, buscando viabilizar o futuro do planeta e a realização pessoal. A Marcha das Margaridas se traduz, hoje, como um movimento específico das trabalhadoras rurais. Ele associa a mulher a uma flor - "margarida" - com atributos de fragilidade, sensibilidade, a uma mulher forte que deu a vida pela luta. Desqualifica o frágil feminino e o transforma em força e eficácia política, na luta pelo seu reconhecimento como categoria social e, na medida em que se consolida como "sujeito político", ampliam suas ações e o seu reconhecimento público. 
A aproximação desta pesquisadora com as mulheres rurais permitiu confirmar que essa luta é permanente, pois garantem alimentos de qualidade e em quantidade suficiente para suas famílias e para comercialização, sem comprometer o meio ambiente. Suas vidas são pautadas na sustentabilidade humana em sintonia com a preservação e a gestão racional dos recursos naturais. Lutam pelo direito de viver em seus territórios com dignidade e pleno exercício da cidadania.

As mulheres rurais desempenham um papel decisivo para 0 alcance dos Objetivos de Desenvolvimento Sustentáveis (ODS), adotados pelas Nações Unidas em substituição aos Objetivos de Desenvolvimento do Milênio (ODMs).

\subsection{GÊNERO E INVISIBILIDADE}

A noção de gênero adquire um duplo caráter epistemológico. De um lado, funciona como categoria descritiva da realidade social, que concede uma nova visibilidade para as mulheres, referindo-se a diversas formas de discriminação e opressão, tanto simbólicas quanto materiais, e de outro, como categoria analítica, como um novo esquema de leitura dos fenômenos sociais.

O movimento de mulheres, na sua longa história de avanços e de amadurecimento, tornou-se muito rico, diversificado e multidisciplinar. Algumas vêm trabalhando a questão de gênero sob a ótica da equidade, da igualdade de direitos, para superar as tradicionais iniquidades existentes entre homens e mulheres no espaço público e privado, as divisões sexuais de trabalho e de poder, assim como com as desigualdades entre as mulheres em distintas organizações e esferas.

A divisão sexual do trabalho tem sido outro importante conceito para compreensão do processo de constituição das práticas sociais permeadas pelas construções dos gêneros a partir de uma base material. A subordinação de gênero, a assimetria nas relações de trabalho masculinas e femininas se manifesta não apenas na divisão de tarefas, mas nos critérios que definem a qualificação das tarefas, nos salários, na disciplina do trabalho.

Araújo (2010), em sua pesquisa sobre Economia Feminista, coloca as questões da contribuição econômica das mulheres para a família e a sociedade, 
procurando analisar a invisibilidade dessa contribuição. No entendimento da autora, as mulheres contribuem para a economia, por meio do trabalho exercido por elas no âmbito familiar, no domicílio e fora desse. Porém, a posição das mulheres na economia continua sendo esquecida, pensamento dominante e invisível na esfera privada.

Historicamente, a partir do sistema capitalista desenvolvido por Adam Smith, o domicílio, antes utilizado como local de produção, da reprodução e do consumo, foi reduzido a alojamento familiar. A participação das mulheres na economia foi reduzida à esfera doméstica a partir da Revolução Industrial. Araújo (2010) pontua que, atualmente, a metade da população global do trabalho é composta por mulheres, e a posição econômica das mesmas pouco foi mudada. $O$ trabalho feminino no âmbito familiar não é medido adequadamente pelo PIB, por ser considerado um trabalho invisível, não pago.

No esquema circulatório da economia, só aparece o trabalho formal e regulamentado das mulheres. As atividades domésticas, tais como o cuidar dos filhos e idosos, o preparo dos alimentos, a limpeza da casa, entre outros, não são consideradas, permanecendo na gratuidade e invisibilidade. Outras atividades domésticas são consideradas como ocupações em horas de lazer. É o entendimento de Araújo (2010), corroborado por esta pesquisadora.

No que concerne ao uso do tempo, as pesquisas demonstram que as mulheres dedicam um número mais elevado de horas semanais às jornadas de trabalho doméstico. Com maior destaque àquelas que desempenham dupla jornada de trabalho, ou seja, dentro e fora de suas casas. A participação das mulheres no mercado de trabalho não foi acompanhada da redução da jornada dupla em casa.

Araújo (2010) argumenta, também, que as mulheres contribuem efetivamente no sistema econômico da sociedade, tanto no trabalho formal quanto no informal. $\mathrm{O}$ trabalho informal, doméstico, apesar de não ser contabilizado economicamente, permanecendo na gratuidade e invisibilidade, contribui para o consumo de bens e serviços.

A igualdade de gênero e o empoderamento das mulheres são cruciais para alcançar os três pilares do desenvolvimento sustentável, que são o econômico, o social e a ambiental, bem como para ampliar o protagonismo das mulheres na sociedade. 


\subsection{GÊNERO EM ASSENTAMENTOS RURAIS}

Estas questões são importantes para destacar o fator feminino no ambiente rural como essencial na gestão ambiental, na produção de alimentos e na reprodução social, ao mesmo tempo em que contribui na transição para uma economia verde. As mulheres são protagonistas no processo de adaptação e mitigação da atividade agropecuária à mudança climática.

Um quarto da população feminina mundial vive no campo. São líderes, tomadoras de decisão, trabalhadoras, empresárias e fornecedoras de serviços. Sua contribuição é vital para o bem-estar das famílias e das comunidades, bem como para a economia local e a dos países, apesar da invisibilidade das contribuições econômicas dessas mulheres, segundo Araújo (2010).

A interação de gênero com a gestão ambiental pode ser vista no trabalho das mulheres dos assentamentos rurais. A prática do turismo comunitário nos assentamentos apresenta uma possibilidade de valorização do trabalho das mulheres e consequente visibilidade e empoderamento. A questão de gênero também se destaca na discussão referente à implantação da atividade turística no meio rural no campo do saber fazer alimentar. Torna-as protagonistas nesse cenário, valorizando o trabalho realizado pelas mesmas, tanto dentro do espaço do assentamento quanto pelos visitantes/turistas. Há uma inversão da conotação simbólica da divisão sexual do trabalho executado. Enquanto no trabalho agrícola é a mulher quem "ajuda" ao homem, não tendo seu trabalho reconhecido com a mesma intensidade do masculino, no turismo, é o homem quem "ajuda" a mulher em algumas tarefas.

O turismo, nesse sentido, pode ser percebido como um vetor dessa busca feminina ao torná-las "visíveis" tanto no âmbito do assentamento quanto da sociedade na qual se inserem através do "olhar do turista". Todavia, é preciso evitar o pensamento do turismo como panaceia, afinal, nem são só impactos positivos que o desenvolvimento da atividade pode ocasionar. 


\section{O CAMINHO TEÓRICO-METODOLÓGICO}

Após situar o objeto desta dissertação em um contexto teórico interdisciplinar, considerando, para tanto, as contribuições de autores em torno de conceitos sobre turismo, pluriatividade, multifuncionalidade, sustentabilidade, questões de gênero e ecofeminismo, apresentam-se aqui as estratégias metodológicas percorridas para que os objetivos desta pesquisa fossem alcançados.

Assim, a escolha do método e das técnicas utilizadas para a realização desta pesquisa científica em Turismo foi de suma relevância para iniciar a busca de sentido do Turismo em Assentamento Rural, na perspectiva de contribuir para o protagonismo e ampliação da visibilidade das mulheres agricultoras, bem como fortalecer as práticas de sustentabilidade em suas dimensões econômica, ambiental, sociocultural e político-institucional.

Ao se buscarem os caminhos metodológicos a serem percorridos, encontrouse em Goldenberg (2004, p. 105) o significado etimológico do termo "metodologia", que a aponta como "o estudo dos caminhos a serem seguidos, dos instrumentos usados para se fazer ciência".

De forma complementar, Paviani $(2009$, p.12) afirma que o método se refere aos recursos estratégicos, aos modos de conhecer e ao tipo de linguagem e de concepção ontológica, tipificados, sob a perspectiva do conhecimento, nos modos analíticos, dialéticos e hermenêuticos.

Assim, com a finalidade de percorrer um caminho metodológico para a construção desta pesquisa, e para uma melhor organização e clareza neste processo, foram utilizados os recursos estratégicos descritos a seguir.

\subsection{O TIPO DE PESQUISA - MÉTODO QUALITATIVO}

A investigação do tipo qualitativa foi utilizada nesta pesquisa com abordagem interpretativa inspirada em Geertz (2008), um dos principais representantes desse tipo de abordagem, o qual propõe um modelo de análise cultural hermenêutico. Para ele, o antropólogo deve fazer uma descrição em profundidade, "descrição densa" 
das culturas como "textos" vividos, como "teias de significados" que devem ser interpretados. Nesse viés, Creswel (2007) aponta que a pesquisa qualitativa é fundamentalmente interpretativa, ou seja:

O pesquisador faz a interpretação dos dados, descreve as pessoas, - cenário, analisa os dados para identificar temas ou categorias; finalmente, faz interpretações e tira conclusões sobre 0 seu significado, pessoal e teoricamente (CRESWELL, 2007, p. 186).

As abordagens de Goldenberg (2004, p. 14) indicam que na pesquisa qualitativa a preocupação do pesquisador não é com a representatividade numérica do grupo pesquisado, mas com o aprofundamento da compreensão de um grupo social, de uma organização, de uma instituição, de uma trajetória, entre outros. Essa preocupação se fez presente no processo de pesquisa junto aos agricultores rurais, notadamente as mulheres, na busca de compreensão dos processos de organização social, na trajetória de luta pela posse da terra, no associativismo, e nas relações internas e externas.

No viés da abordagem interpretativa, convém fazer uma colocação proposta por Demo (2000) de que na pesquisa qualitativa buscam-se depoimentos que colaborem com dados relevantes para o entendimento do lado subjetivo dos fenômenos. Tais depoimentos encontram-se registrados no escopo deste trabalho, confirmando o entendimento do autor.

Esta colocação vem ao encontro de Minayo (2007) na afirmação de que o método qualitativo responde a questões muito particulares com um nível de realidade que não pode ou não deveria ser quantificado. Ele visa ao universo da produção humana e suas relações, representações e intencionalidades, os quais dificilmente podem ser traduzidos em dados quantitativos, pois

[...] ela trabalha com o universo dos significados, dos motivos, das aspirações, das crenças, dos valores, das atitudes. Esse conjunto de fenômenos humanos é entendido aqui como parte da realidade social, pois o ser humano se distingue não só por agir, mas por pensar sobre o que faz e por interpretar suas ações dentro e a partir da realidade vivida e partilhada com seus semelhantes (MINAYO, 2007, p. 21).

A descrição de comportamentos, percepções, ações, confianças e características da realidade (MINAYO, 2007) se observa nesta pesquisa, pois esse tipo de metodologia permitiu aumentar a compreensão sobre o fenômeno em estudo. 
A profundidade proposta na pesquisa teve um nível descritivo, porque procurou aprimorar ideias ou descobrir intuições. Segundo Gil (2008), o trabalho descritivo possibilita abranger aspectos gerais e amplos de um contexto, como situação social, econômica e política das minorias e opiniões comunitárias, dentre outros.

Os caminhos percorridos para o desenvolvimento desta pesquisa são apresentados a seguir. As estratégias utilizadas visaram obter uma visão panorâmica do objeto de estudo aqui contemplado.

\subsection{ABORDAGEM ETNOGRÁFICA}

Para compreender as percepções e significados dos produtores rurais de Chapadinha - DF foi adotado a pesquisa etnográfica a qual permite, segundo Geertz (1989), uma descrição densa. Fazer etnografia, diz o antropólogo, é como tentar ler (...) um manuscrito estranho, desbotado, cheio de elipses, incoerências, emendas suspeitas e comentários tendenciosos, escrito não com os sinais convencionais do som, mas com exemplos transitórios de comportamento modelado."

Para Geertz (1989), a etnografia é interpretativa e microscópica (os antropólogos não estudam as aldeias, eles estudam nas aldeias). Assim, esta pesquisadora "mergulhou no meio" da comunidade rural Chapadinha-DF para observar o dia a dia dos agricultores.

O estudo etnográfico foi, portanto, pertinente nesta pesquisa dado o enfoque na aproximação da percepção da realidade, visando à reconstrução histórica, ao reavivar as lembranças da vida, da memória e do cotidiano do grupo de assentados rurais. Desta forma, as atividades etnográficas se relacionaram com a organização da pequena produção familiar rural e com o lugar das mulheres nos espaços dessa produção e fora dela, como também com outras observações relevantes do cotidiano do assentamento.

Assim, amparada em Geertz (1989), esta pesquisadora recorreu à prática etnográfica para estabelecer relações, selecionar informantes, transcrever textos, levantar genealogias, mapear campos, manter um diário, e assim por diante. O que define esse método é o tipo de esforço intelectual que ele representa: um risco 
elaborado para uma "descrição densa", estabelecendo uma aproximação em que "olhar as dimensões simbólicas a ação social - arte, religião, ideologia, ciência, lei, moralidade, senso comum - não é afastar-se dos dilemas existenciais da vida [...]; é mergulhar no meio delas".

\subsection{PROCEDIMENTOS TÉCNICOS DE COLETA DE DADOS}

\subsubsection{Estudo de Caso}

O Estudo de Caso foi utilizado nesta pesquisa como um modo de investigação, por ser um campo mais ou menos "construído" (real-artificial), mais ou menos "limitado" (aberto-fechado), mais ou menos "manipulável (descontroladocontrolado), de acordo com Bruyne et al. (1982, p. 224).

$\mathrm{Na}$ visão desses autores, o Estudo de Caso reúne informações tão numerosas e tão detalhadas quanto possível com vistas a apreender a totalidade de uma situação. Por isso, eles pontuam que recorrem a técnicas de coleta de informações igualmente variadas (observações, entrevistas, documentos) e frequentemente refinadas: observação participante, sociometria aplicada à organização, pesquisa de tipo etnográfico.

À luz dos conceitos de Bruyne et al., tal modelo investigativo foi entendido como sendo aplicável junto à comunidade do Assentamento Rural de ChapadinhaDF, uma vez que, "em larga medida, os estudos de caso inspiram-se numa doutrina empirista apoiada na pretensa recusa de qualquer teoria e na conviç̧ão de que o simples acúmulo de fatos trará uma explicação satisfatória das situações reais". 


\subsubsection{Pesquisa bibliográfica}

Na pesquisa bibliográfica, esta pesquisadora fez uso das publicações sobre as propriedades de assentamentos rurais, a agricultura familiar, projetos $\mathrm{e}$ programas destinados ao meio rural, ecofeminismo, e sustentabilidade, buscando, com essas obras, fundamentar seus argumentos. Esse procedimento encontra respaldo em Marconi e Lakatos (2006, p. 160), as quais apontam que:

[...] a pesquisa bibliográfica é um apanhado geral sobre os principais trabalhos já realizados, revestidos de importância, por serem capazes de fornecer dados atuais e relevantes relacionados com o tema. O estudo da literatura pertinente pode ajudar a planificação do trabalho, evitar publicações e certos erros, e representa uma fonte indispensável de informações, podendo até orientar as indagações.

Para Dencker (2007, p. 152), "a pesquisa bibliográfica permite grau de amplitude maior, economia de tempo e possibilita o levantamento de dados históricos". Porém, é necessário um estudo aprofundado acerca da teoria pesquisada, procurando fontes que relatem o mesmo tema a fim de desenvolver o trabalho, sem erros.

As obras que deram suporte referencial enriquecedor para desvelar as questões aqui levantadas estão relacionadas na bibliografia deste trabalho, sendo, portanto, dispensável relacioná-las neste espaço.

Os documentos legais pertencentes à comunidade assentadas que aportam a legitimação do espaço territorial do assentamento, bem como a vinculação do movimento de ocupação a instituições representativas dos sem terra, não estão abordados nesta pesquisa por motivos de cuidado na preservação ou no sigilo dessas informações, por parte da pesquisadora.

Seguindo os mesmos passos da pesquisa bibliográfica, foram também analisados estatutos e editais, já referidos neste capítulo, os quais respaldam as posições oficiais a respeito do turismo rural comunitário e as questões relativas a assentamentos rurais, dentre outros. 


\subsubsection{Pesquisa de campo}

A pesquisa de campo constou da coleta de dados a partir de entrevistas abertas e semiestruturadas e da observação participante realizadas junto aos sujeitos do assentamento, em especial com as mulheres, no próprio espaço rural e em feiras e entrepostos de produtos agrícolas. Tais dados visaram confirmar ou refutar o problema da pesquisa e resultaram em registros da pesquisadora.

Na pesquisa de campo pretendeu-se identificar o histórico da comunidade, as relações de gênero dentro da comunidade, a organização comunitária, as práticas agroecológicas, a vida em sociedade nas dimensões política, cultural, econômica, humana.

Marconi e Lakatos (2006) resumem a pesquisa de campo a simples observação dos fenômenos do dia a dia, como ocorre espontaneamente.

De acordo com Minayo (1994, p. 53), a pesquisa de campo é "o recorte que o pesquisador faz em termos de espaço, representando uma realidade empírica a ser estudada a partir das concepções teóricas que fundamentam o objeto da investigação. Ou seja, é a escolha de uma área para aplicar a teoria da pesquisa.

Para o exercício desse procedimento metodológico, a pesquisadora estreitou o relacionamento com a comunidade do assentamento rural realizando visitas em diversos momentos, integrando-se a reuniões para defender interesses específicos das mulheres e participando de festa promovida pelos assentados.

\subsubsection{Pesquisa descritiva}

Segundo Gil (2008), as pesquisas descritivas têm como objetivo primordial a descrição das características de determinada população ou fenômeno ou, então, o estabelecimento de relações entre variáveis. As técnicas padronizadas de coleta de dados, o questionário e a observação sistemática, são alguns de seus aspectos mais significativos. Entre as pesquisas descritivas, Gil (2008) destaca aquelas que têm por objetivo estudar as características de um grupo: sua distribuição por idade, 
sexo, procedência, nível de escolaridade, estado de saúde física e mental, entre outros.

Nesse viés, esta pesquisadora ouviu e registrou o cotidiano dos campesinos agricultores rurais, as posturas inerentes às diversas características do grupo social, tais como as questões de gênero, escolaridade, procedências, trabalho, renda familiar, participação política, e outras.

\subsubsection{Observação participante}

Nas fases de observação, esta pesquisadora anotou falas dos atores, cenários, episódios diversos, fez registros fotográficos e, em determinados momentos, percebeu-se envolvida em papéis e até mesmo participando integralmente.

Minayo (2010) define a observação participante como um processo pelo qual um pesquisador se coloca como observador de uma situação social, com a finalidade de realizar uma investigação científica. "Aprender a se colocar no lugar do outro". Essa é a filosofia que fundamenta a observação participante, ou seja, é a necessidade que todo pesquisador social tem de relativizar o espaço social de onde provém, esclarece Minayo (2010). E acrescenta: o principal instrumento de trabalho de observação é o chamado diário de campo.

O caminho para o desenvolvimento desta pesquisa teve inicio com a observação direta in loco. A apropriação da observação participante na pesquisa de campo costuma apontar dificuldades desde a aproximação do pesquisador com o seu objeto de pesquisa até a negociação para a imersão no lugar. Porém, esta pesquisadora já encontrou receptividade no contexto do assentamento por alguns membros, na sua maioria mulheres, o que significou certa facilidade para o exercício do trabalho de observação.

Nesse procedimento, é importante um cuidado maior com as interferências inconvenientes que a intimidade entre 0 pesquisador e 0 pesquisado poderá incorrer. Há que se atentar para o fato de que é fundamental a observância dos limites na comunicação verbal, social e pessoal. 
No caso específico dos assentamentos rurais, o histórico desses movimentos sociais no Brasil gerou um sentimento de censura por parte da sociedade urbana, com consequentes e diversas abordagens preconceituosas. Portanto, esta pesquisadora buscou estabelecer um grau de confiança, respeito e atenção para com os sujeitos do assentamento rural Chapadinha-DF, tendo em vista o seu histórico de luta, e de superação dos estigmas oriundos da sociedade urbana.

\subsubsection{Entrevista aberta e semiestruturada}

A entrevista aberta, semiestruturada ou desestruturada (Creswell, 2007), foi escolhida como a principal técnica a ser utilizada por se tratar de um instrumento flexível para a coleta dos dados. As entrevistas aplicadas nesta pesquisa ocorreram de forma espontânea, a partir dos diálogos junto aos agricultores da comunidade de Chapadinha DF, com ênfase nas mulheres e seus cotidianos.

Segundo Marconi e Lakatos (2011), "a entrevista é um encontro entre duas pessoas, a fim de que uma delas obtenha informações a respeito de determinado assunto, mediante uma conversação de natureza profissional". Os encontros da pesquisadora com os agricultores rurais ocorreram, em quase todos os momentos, em grupo, sem protocolo rigoroso.

As vantagens da entrevista estão no fato de que pode ser utilizada com todos os segmentos da população e fornece uma amostragem muito melhor da população em geral. As desvantagens da entrevista estão na dificuldade de expressão e comunicação de ambas as partes, o que pode levar a uma falsa interpretação das perguntas. Existe a possibilidade de o entrevistado ser influenciado, consciente e inconscientemente, pelo entrevistador (MARCONI; LAKATOS, 1996). 


\subsection{O LÓCUS DA PESQUISA}

\subsubsection{Lago Oeste (DF) - Vocação ecoturística}

O Assentamento Rural Chapadinha recebe essa denominação por sua localização na Chapada da Contagem, unidade geomorfológica mais elevada do Distrito Federal, com altitudes que variam entre 1.000 a 1.200 metros, onde foi implantada a Reserva Biológica da Contagem.

O nome "Contagem" tem um referencial histórico, possui um valor cultural, pois abriga um sítio histórico ainda não localizado, conhecido como Contagem de São João das Três Barras - postos fiscais da coroa portuguesa instalados no local em 1734/36, para onde convergia o fluxo das minas de Tocantins e Goiás com destino a Minas Gerais e onde se "contavam" os escravos. Pesquisadores localizaram, em três locais, artefatos em pedra datando de oito mil anos. Em outro ponto, o historiador Wilson Vieira Júnior localizou traços da movimentação mercantil que cruzava a reserva pela Estrada Real da Bahia entre os séculos XVIII e XIX.

A Reserva Biológica da Contagem abrange uma área de 3.460 hectares e foi criada com o objetivo de preservar os remanescentes de cerrado e os recursos hídricos que ocorrem no topo e encostas da Chapada. Localiza-se ao norte do Distrito Federal, limitando-se ao sul com a rodovia DF 001 e o Parque Nacional de Brasília; a oeste com o Núcleo Rural Lago Oeste; a leste com os condomínios do Setor Habitacional Grande Colorado e Região Administrativa de Sobradinho II e ao norte com a rodovia DF 150, conforme Figura 4, abaixo. 
Figura 4 - Rodovia DF 001; Chapada da Contagem; Parque Nacional de Brasília, esquerda; Reserva Biológica da Contagem e o Núcleo Rural do Lago Oeste-DF, à direita.

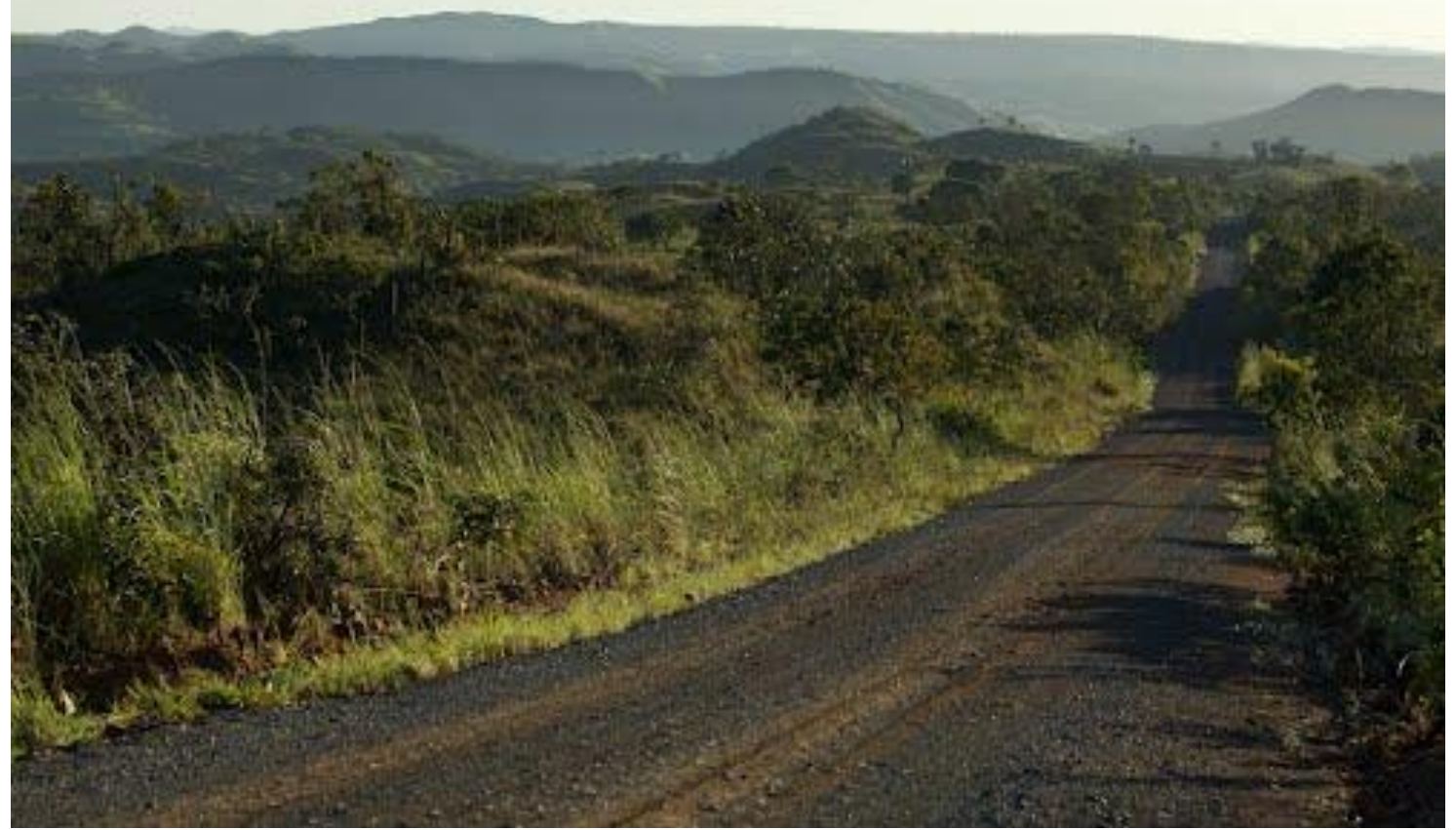

Fonte: $<$ https://www.google.com.br/webhp?sourceid=chrome-instant\&ion=1\&espv=2\&ie=UTF8\#q=chapada+da+contagem >. Acesso em: 03 dez. 2016.

Na região da Chapada da Contagem, está ocorrendo um acelerado processo de ocupação do solo, e a REBIO da Contagem representa a possibilidade de preservação dessa significativa área de cerrado, onde existem espécies da fauna e da flora ameaçadas de extinção, além dos mananciais hídricos fundamentais ao abastecimento público no Distrito Federal. No interior da Reserva há duas captações de água localizadas no ribeirão Contagem e córrego Paranoazinho, que são responsáveis pelo abastecimento público da cidade de Sobradinho. A Reserva propicia a formação de um corredor ecológico entre o PARNA Brasília e a Bacia do Rio Maranhão, garantindo a ligação dessa unidade de conservação com a bacia amazônica e o Núcleo Rural do Lago Oeste (NRLO).

O Núcleo Rural Lago Oeste (NRLO) é o mais ecológico núcleo rural do Distrito Federal. O seu nome derivou da pequena lagoa que existia no centro do Parque Nacional de Brasília, conhecida como Lago Oeste, sendo que essa área, após o encerramento da construção da Barragem ali estabelecida, passou a ser também chamada de Lagoa da Barragem de Santa Maria, que atualmente fornece cerca de $25 \%$ das águas de Brasília. Essa antiga lagoa pode ser avistada no início da própria DF-001, próximo às ruas 00 e 01 do NRLO. 
Esse Núcleo apresenta características da multifuncionalidade agrícola visto que se apresenta como um conjunto de novos aspectos relacionados à atividade agrícola, que não estão ligados diretamente à produção de alimentos e matériasprimas e que vêm sendo reconhecidos como fundamentais para o bem-estar da sociedade. O NRLO é um espaço rural urbanizado, dada a localização geográfica e a proximidade com o centro urbano de Brasília, além da interseção crescente entre a agricultura agroecológica e os demais setores da economia, a oferta de serviços ecoturísticos e uma série de novas demandas que surgem relacionadas às demais funções exercidas pelas atividades agrícolas até então desconsideradas.

Figura 5 - Agricultora do Lago Oeste comercializa geleias na feira, a partir das frutas colhidas na própria propriedade rural.

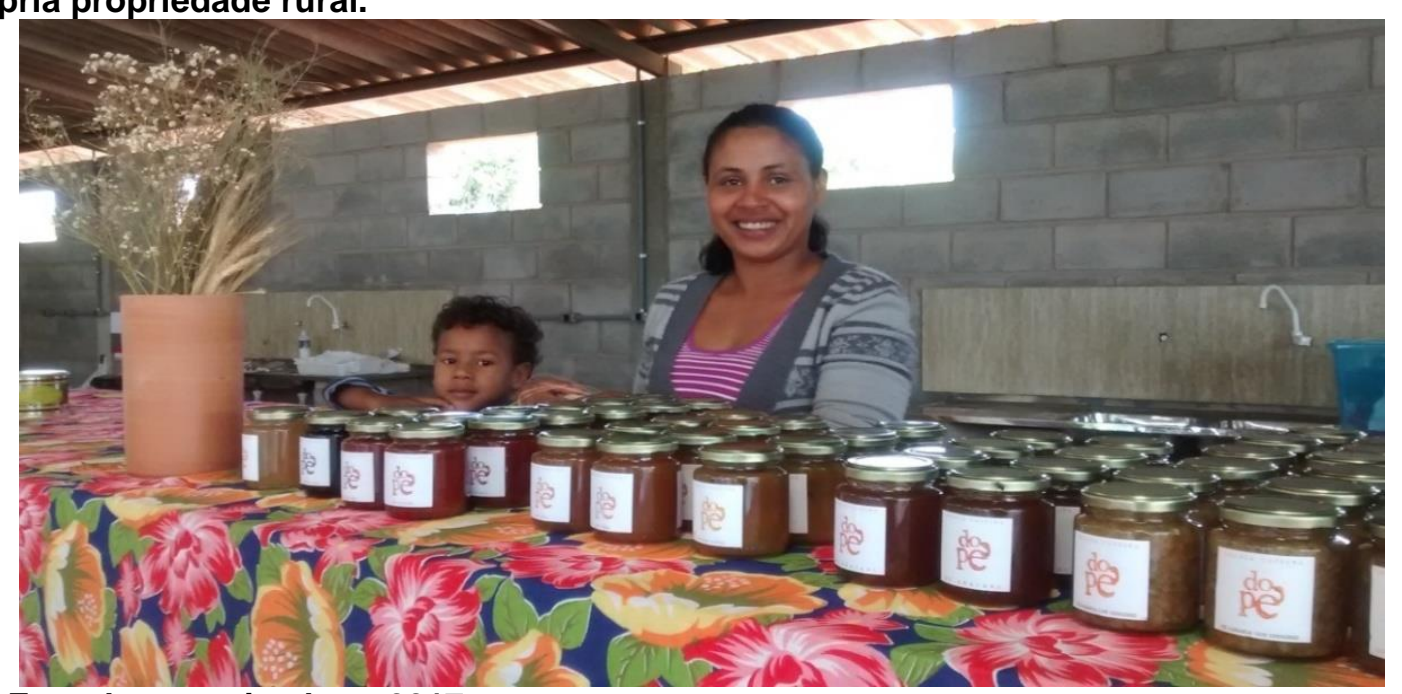

Fonte: Foto da pesquisadora, 2017.

O NRLO foi formado a partir de quatro fazendas: a Contagem de São João e a Palmas/Rodeador, que são de propriedade da União Federal, e as Fazendas do Buraco e do Sítio do Mato, que são particulares e se situam na borda da Chapada da Contagem. É uma área de aproximadamente $35 \mathrm{~km}^{2}$ situada na Região Administrativa de Sobradinho-DF, com cerca de 1.000 pequenas chácaras, todas com dois hectares, com cercas vivas e muitas áreas verdes onde se mantém um agradável clima de campo e de respeito à natureza. Dista, aproximadamente, $40 \mathrm{~km}$ da Rodoviária de Brasília (DF).

Esse Núcleo Rural é tido como a última região de encostas e bordas do Lago Oeste, onde se encontram as mais belas vistas do cerrado do Planalto Central, sendo os pontos mais destacados e conhecidos o do Mirante do Pontal dos Gaviões e o Platô de São Francisco. Dali se avista o Vale da Área de Proteção Ambiental do Cafuringa e a composição de colinas, gargantas e cascatas que compõem o ponto 
extremo da área Nordeste do PARNA de Brasília, a mais de 1.200 metros de altura. Nessa e outras regiões do Lago Oeste. Há ainda grande número de trilhas para caminhadas ecológicas, cavalgadas, passeios e trilhas para bicicletas; cascatas e pequenas lagoas; restaurantes, pousadas e hotéis-fazenda. É, sem dúvida, uma área rural privilegiada ecologicamente, por estar cercada de Unidades de Conservação, a maioria delas federais, com grande potencial agroecológico e com vocação para a produção orgânica e o ecoturismo.

O NRLO conta com uma Associação dos Produtores do Lago Oeste (Asproeste), que representa os proprietários, posseiros e moradores de terras localizadas na Chapada da Contagem. Um dos objetivos dessa Associação é disseminar práticas agrícolas e pastoris, particularmente com a produção de produtos orgânicos e atividades industriais afins, conservação dos recursos naturais do Núcleo Rural, do Parque Nacional de Brasília, da APA do Cafuringa e, também, preservação da vegetação nativa.

Diversas espécies vegetais são cultivadas naquele Núcleo: verduras, hortaliças, espécies raras de pimenta, café e frutas, comercializados in natura ou beneficiados, produtos esses que se destacam no mercado do Distrito Federal pela qualidade, de acordo com informações da Associação dos Produtores Rurais do Lago Oeste. A empresa Cerrado Sucos é um exemplo de empreendimento rural do NRLO. Criada em 2009, cultiva uva com certificação orgânica, produz sucos e geleias e abastece o mercado de Brasília. O Sebrae-DF, por meio da Unidade de Agronegócio, atua naquela região com cursos de capacitação e assessoria para a certificação orgânica dos produtos agrícolas.

Sob a coordenação da Asproeste, foi estruturado o Empório Lago Oeste, que comercializa produtos hortifrutigranjeiros e artesanatos, em especial a produção da agricultura familiar, dos pequenos produtores e da agricultura agroecológica e orgânica (Ver Figura 5, acima). É um empreendimento que valoriza a agricultura familiar, os pequenos produtores, e estimula o consumo de produtos orgânicos e agroecológicos.

Acessar o Núcleo Rural do Lago Oeste é possível a partir do Posto Colorado, em Sobradinho-DF, às margens da BR 020, e seguindo a DF-001, ou a partir da cidade de Brazlândia-DF, seguindo a mesma DF-001, conforme Figura 6, abaixo. 
Figura 6 - Rodovia que dá acesso ao NRLO, sentido Posto Colorado-Brazlândia.

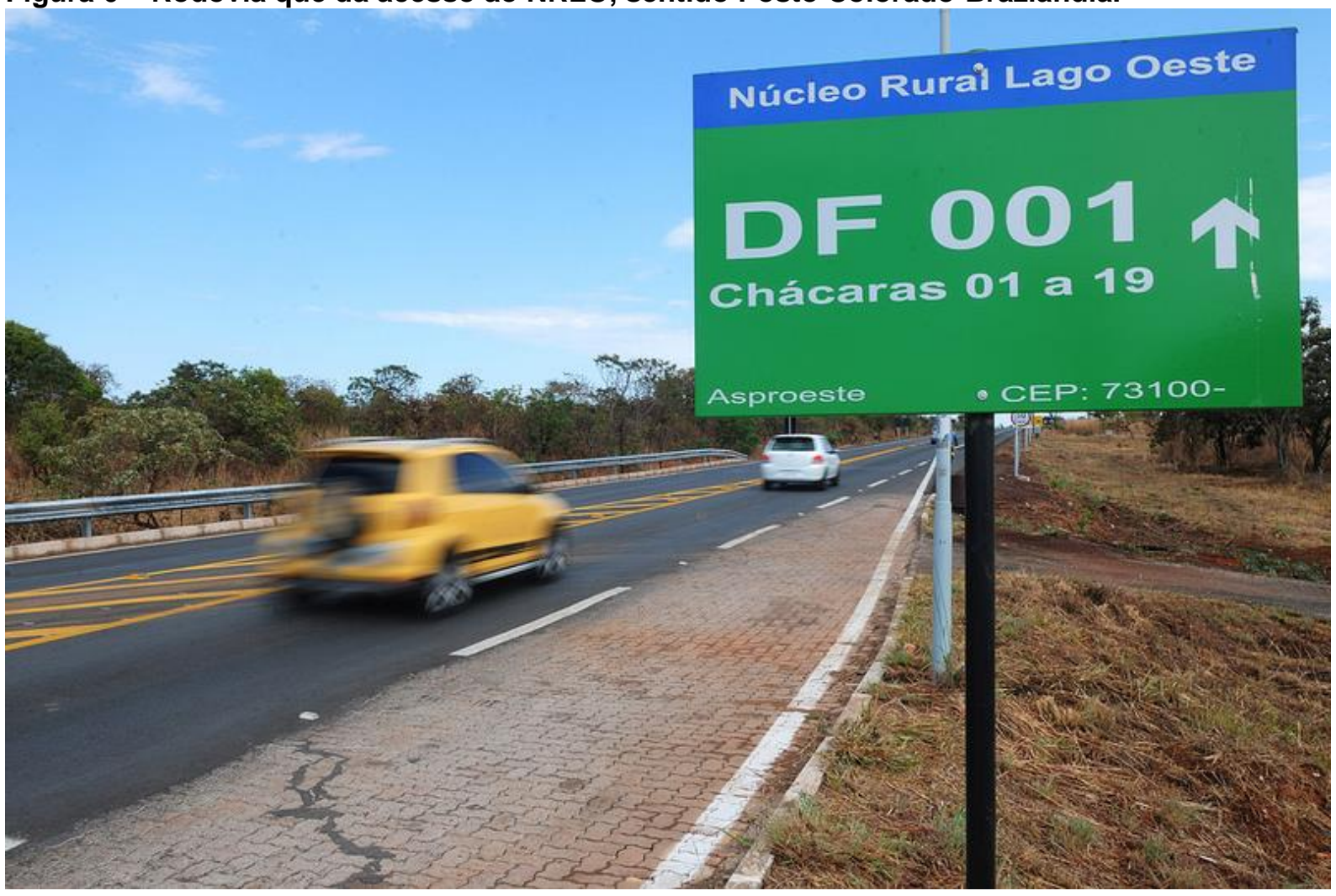

Fonte: $<$ https://www.google.com.br/webhp?sourceid=chrome-instant\&ion=1\&espv=2\&ie=UTF-8 \#q=chapada+da+contagem>. Acesso em: 03 dez. 2016.

\subsection{2 $O$ assentamento da Chapadinha}

Dos testemunhos dos atores e atrizes sociais, aqui concebidos como os sujeitos deste estudo, apresenta-se a análise de alguns fragmentos narrados, colhidos nos dois anos de trabalho de campo. Inicia-se, aqui, a interpretação do objeto de estudo, dando visibilidade ao discurso social dos SEM TERRA de Chapadinha. Dada a especificidade do tema e a complexa teia de significações observadas em campo, busca-se uma aproximação sobre o que pensam e sentem as famílias ainda acampadas, portanto em processo de Assentadas, voltando um olhar indagador, admirador e respeitoso às famílias agricultoras, muitas delas conduzidas pelo trabalho das mulheres. 


\subsection{O PRIMEIRO ENCONTRO}

Fazer a etnografia é como tentar ler (no sentido de
"construir uma leitura de") um manuscrito estranho,
desbotado, cheio de elipses, incoerências, emendas
suspeitas e comentários tendenciosos, escrito não com os
sinais convencionais do som, mas com exemplos
transitórios de comportamento modelado.

(GEERTZ, 2008, p. 7).

Inspirada em Geertz, esta pesquisadora se situou entre os moradores de Chapadinha por quase dois anos.

No km 05 da DF170, rua 25, do Lago Oeste, localiza-se o Assentamento Rural de Chapadinha. Logo à esquina da rua se avistam alguns barracos feitos de pedaços de madeira e lonas pretas. O silêncio predomina naquele lugar. À primeira vista parece apenas um lugar muito seco, empoeirado, abandonado, triste. Pura ilusão.

Ao entrar em qualquer barraco e encontrar uma família, um copo d'água fresco, folhas de alface bem fresquinhas, um agricultor ou uma agricultora trabalhando na plantação, na colheita, na higienização e embalagem dos produtos, a primeira impressão muda completamente. Ali é um espaço abençoado, acolhedor, hospitaleiro. Aquele pedaço de chão é o resultado de muita luta, muito trabalho.

Em junho de 2015, esta pesquisadora visitou o Assentamento pela primeira vez, conforme registrado na Figura 7, abaixo. Conheceu o agricultor A. N., sua esposa e filhos, em uma feira agroecológica do Lago Oeste, onde vende seus produtos e de outros agricultores todos os sábados. Naquele encontro, foi convidada por ele para conhecer o assentamento, o que aconteceu no domingo seguinte. Com muita atenção, A. N. Ihe apresentou a mandala, explicou todo o procedimento de plantio que, obrigatoriamente, deve ser adotado como método de cultivo orgânico. Essa é uma marca registrada dos agricultores do assentamento. 
Figura 7 - Agricultor do assentamento em feira popular.

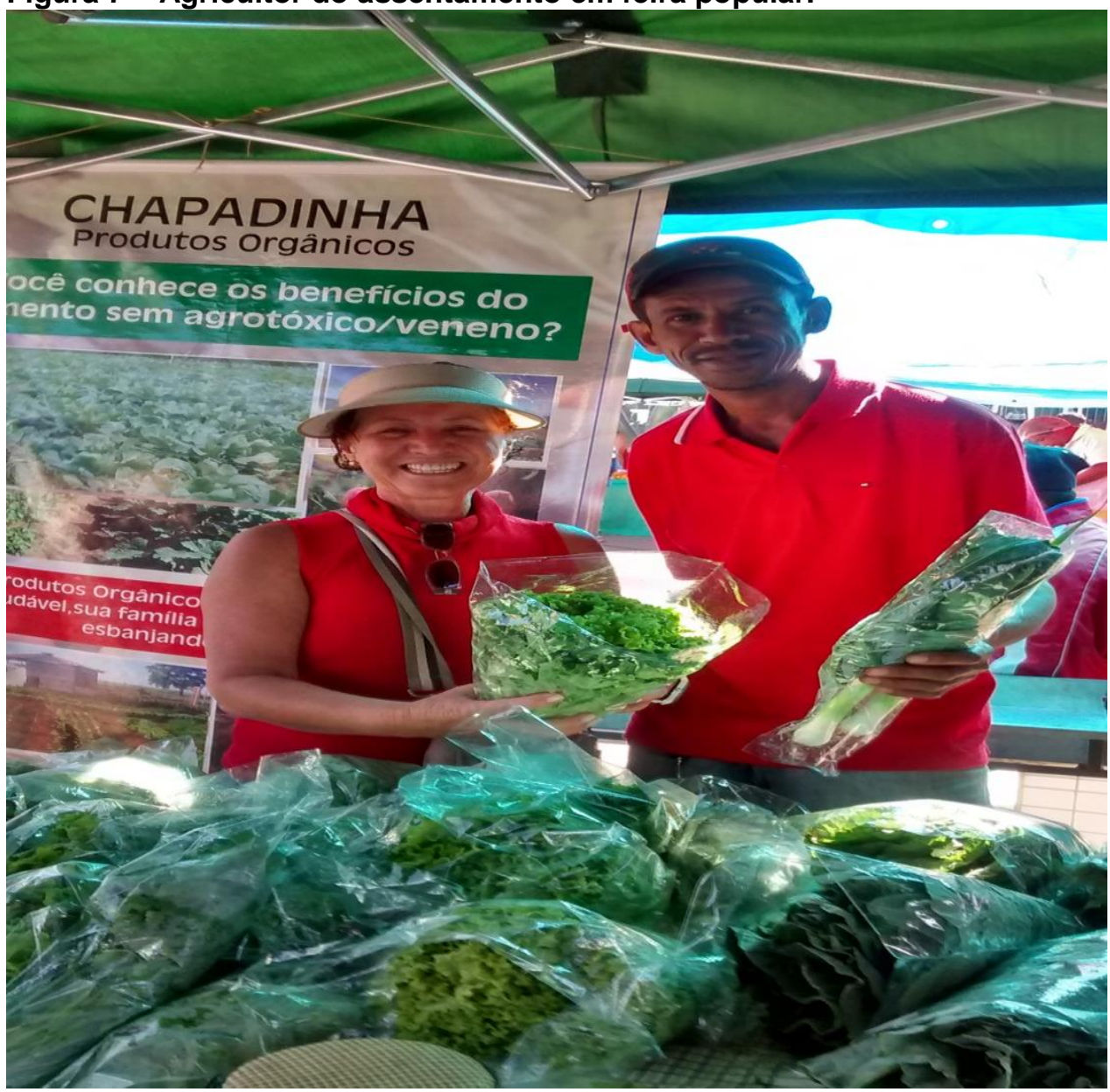

Fonte: Foto da pesquisadora, 2017.

$\mathrm{Na}$ segunda visita ao assentamento, esta pesquisadora foi recebida com muito carinho pela agricultora L. no barraco da Associação dos Trabalhadores Rurais do Assentamento Chapadinha (Astraf), onde participava de uma reunião com técnicos da EMATER-DF. Hoje, o salão já está construído em alvenaria e destina-se a reuniões oficiais e sociais.

L. é uma mulher forte, determinada, que lida na plantação todos os dias "faça chuva ou faça sol", conforme declara. Na ocasião, usava um boné que protegia cuidadosamente os cabelos curtos, pintados de vermelho. O sorriso largo, olhos verdes, voz firme. Aquele encontro foi o início de uma amizade que ficou. Passou a me chamar, carinhosamente, de "Ardoca". A trajetória de vida dessa mulher constitui uma fonte de inspiração para tantas outras mulheres que anseiam por uma porta de saída de situações de pobreza e opressão.

A agricultora tem três filhas e sete netos. Trabalhou como doméstica em casas de Brasília-DF, e se encantou pelo cultivo de hortaliças ao conseguir um 
emprego na área rural. Após esse emprego, ingressou na luta dos Sem Terra e, "virou" "agricultora familiar e trabalho para mim mesma", como afirma orgulhosa.

Atualmente, ela e o marido, principal ajudante, produzem mais de 30 tipos de alimentos, como frutas, legumes, verduras e hortaliças - todas de maneira agroecológica - em uma área de dois hectares no assentamento, onde moram há cerca de doze anos. "Aqui, na produção, eu tenho que decidir tudo", diz ela. "Até prá escolher o pé de alface que vai vender, eu tenho que tá junto, senão não colhe". Parte da produção tem destino garantido. Desde 2012, L. vende para o Programa de Aquisição de Alimentos (PAA) do Governo Federal. "Minha vida está 100\% melhor do que antes. Os programa do governo me deu uma nova esperança", garante a agricultora familiar, que também é beneficiária do Bolsa Família. Ela comercializa os seus produtos na feira das Centrais de Abastecimento do Distrito Federal S/A (Ceasa) aos sábados pela manhã e, às quartas-feiras, dentro de um condomínio residencial, à noite (Ver Figura 8, abaixo). Todos os dias ela está pronta às seis horas da manhã para cuidar da horta. Segundo a agricultora, o destino prioritário é a mesa da família: "A minha plantação eu fiz pensando em mim e nos meus netos. $E$ muito importante para a nossa saúde".

Há nove anos no assentamento Chapadinha, a família se sente feliz por estar conseguindo comercializar a produção.

Figura 8 - A agricultora em ponto de venda de seus produtos.

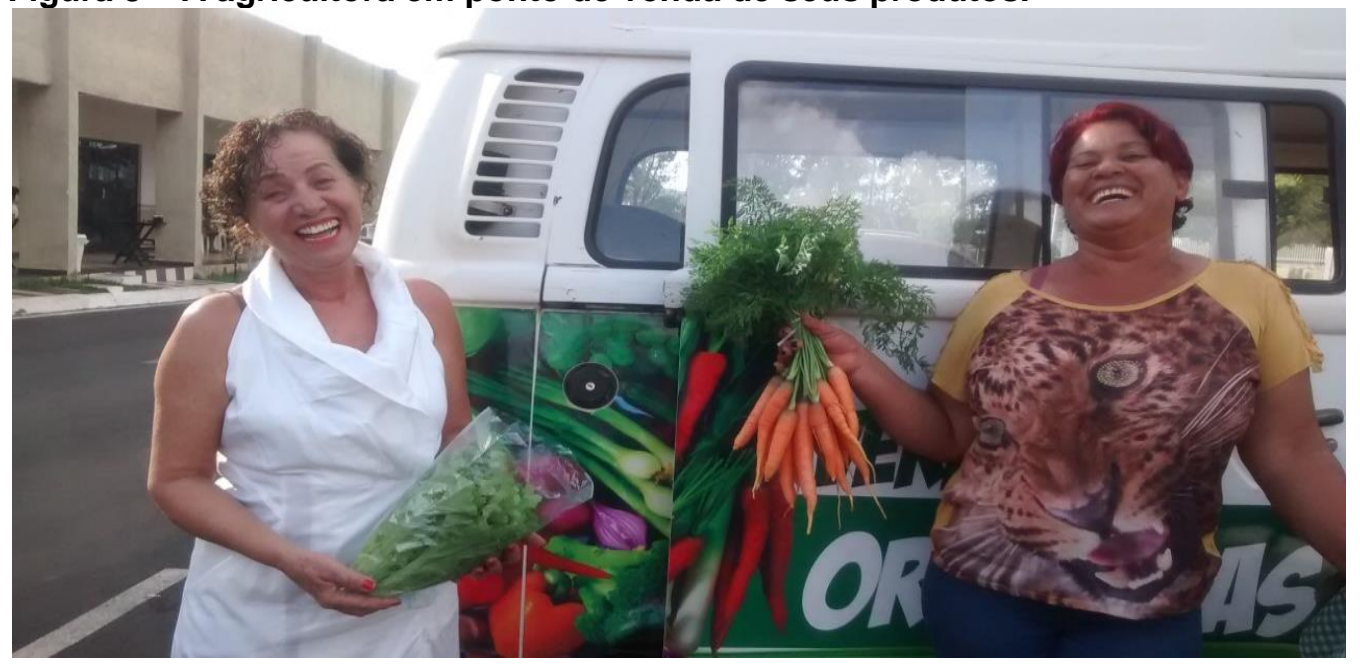

Fonte: Foto da pesquisadora, 2017. 


\subsubsection{O lugar sagrado e a trajetória de luta}

Volta-se, aqui, à descrição das unidades distribuídas no Assentamento. Duas unidades são de uso comum. Em uma delas foi construída a sede da Astraf, com um salão para reuniões, treinamentos e pequenos eventos. A área externa é cedida aos agricultores que não dispõem de água para plantio em suas unidades, onde cultivam seus produtos utilizando os reservatórios construídos pela Associação.

Nesse espaço social, ou na área destinada ao serviço público - assim o identificam os agricultores F. e a Irmã C., em conversa com esta pesquisadora -, a comunidade pretende construir a igreja, um museu e instalações adequadas para recepção aos visitantes que hoje são representados por estudantes/pesquisadores e técnicos de setores público e privado.

No museu, pretende-se expor materiais diversos que retratam a história do assentamento, como fotografias, documentos oficiais, publicações diversas, utensílios agrícolas e domésticos e diversos outros itens importantes e representativos da comunidade. Ela, inclusive, guarda um ferro de passar roupa, aquecido a brasa, que poderia ser doado ao museu, como também uma fotografia com a ex-Presidente Dilma Rousseff, quando recebeu o Prêmio mulheres rurais que produzem o Brasil sustentável, do qual trataremos mais adiante. O agricultor Freire, que promoveu a participação das mulheres nesse certame, guarda em sua residência um acervo considerável de documentos oficiais do Assentamento, além de matérias jornalísticas e fotografias dos eventos promovidos no espaço social, em sua maioria sob a sua coordenação.

Nesse espaço público, são realizadas as Festas da Pamonha, desde 2008, em área aberta onde se improvisam barracas cobertas de palha, destinadas à venda de produtos agrícolas, bolos, doces, bebidas e comidas típicas de festas de São João. Um grande palco também é montado para o desfile das candidatas a Miss Chapadinha. Caixas de som de excelente qualidade reproduzem os avisos e as músicas que animam a festa. No espaço de chão batido, a comunidade e os convidados dançam até a madrugada. A festa tem duração de dois dias e é promovida pela Associação dos Trabalhadores Rurais do Assentamento Chapadinha (Astraf). 
As pamonhas consumidas no local são oferecidas gratuitamente pela Astraf e preparadas pelos próprios agricultores, bem como o arroz de carreteiro ou a galinhada que a agricultora L. prepara com todo o entusiasmo. Em 2015 participei do último evento na preparação das pamonhas juntamente com os agricultores. $O$ batepapo, as aulas de montagem das pamonhas, o convívio com os agricultores se estenderam durante todo o dia até a noite, quando começou a festa.

Reporto-me assim a Geertz (1989), ao perceber que

[...] isso leva à visão da pesquisa antropológica como uma atividade mais observadora e menos interpretativa do que ela realmente é. Situar-nos, um negócio enervante que só é bem-sucedido parcialmente, eis no que consiste a pesquisa etnográfica como experiência pessoal (GEERTZ, 1989, p. 7).

Também naquele espaço são realizados os cultos evangélicos em um barraco bem simples, organizados pelas Irmãs C. e S. todos os domingos e em ocasiões especiais. Os cultos são celebrados normalmente apenas com a presença das duas agricultoras, porque a maioria dos acampados comunga outras religiões, e o pastor evangélico comparece uma vez a cada mês. Detalhe importante: antes da abertura da Festa da Pamonha é celebrado um culto evangélico, por recomendação dos assentados religiosos.

O lugar é sagrado, diz Irmã C., porque "ali começou a luta e por isso ali deve ser construída a igreja". Localiza-se logo à entrada de um dos acessos ao Assentamento. Irmã C. começa a contar trechos da luta enfrentada pelas 400 famílias sem terra no mês de junho de 2005, quando 400 famílias decidiram ocupar a Fazenda Chapadinha que estava em área da União, mas era utilizada para plantio de soja.

No início de 2006, o movimento resolveu demarcar toda a área em 187 parcelas de 2,5 hectares por família, as quais foram distribuídas por sorteio. Deram início a uma plantação e criação de animais.

No dia 08 de fevereiro de 2007, por determinação judicial, foram retirados para uma área distante, a 50 quilômetros de distância. Houve destruição de plantações e morte de animais.

Ainda em 2007, 39 famílias retornaram e reconstruíram seus barracos e reiniciaram os plantios. A área foi novamente medida, ocupando toda a extensão da Fazenda Chapadinha. Foram demarcadas 46 propriedades, distribuídas por sorteio. 
As Áreas de Proteção Permanente foram preservadas. E esse foi o início oficial da ocupação da fazenda. O grileiro não aceitou a invasão e reagiu.

Irmã C. fala com a autoridade que lhe confere sua participação em toda a trajetória de luta dos assentados:

A luta começou. Foram cinco dias sem dormir. Muita bomba, queima de pneus, enfrentando os capanga do grileiro... Os homens dormiam de dia, enquanto as mulheres, de dez em dez, guardavam a entrada do acampamento, enfrentando os capangas que subiam no trator, faziam streep e ameaçavam estuprar as mulheres. Um dia, pegamo um dos capanga dormindo, amarramo o homem no pé de uma árvore, tiramo a roupa dele, pegamo facão e ameaçamos: agora você não vai estuprá mais ninguém. Nós vamos castrá você. O homem chorava, tremia, se urinava todo. E as mulheres riam, se divertiam. Passado um tempo, soltamo o homem que não voltou mais, e os outros capangas também não. (Irmã C., 2016)

Parecia que a luta tinha terminado. Montaram as barracas, começaram a se acomodar no novo espaço. Demarcaram a área em 187 parcelas de 25 hectares para cada família e deram início a uma plantação e criação de animais. A paz aparente foi interrompida no dia 8 de fevereiro de 2007. Por determinação de liminar da justiça foi realizada a retirada a retirada das famílias. O Incra arranjou outro acampamento, em Padre Bernardo, a 50 km de distância, e com a polícia montada, helicóptero sobrevoando a área e maquinário,

arrancou todas as famílias dali, jogando nos caminhões de qualquer maneira as panelas, comidas crua e cozida, roupas, fogão, galinha, tudo o que viam pela frente. Era arroz, feijão, açúcar, tudo espalhado pelo chão. Teve até troca de tiro. (Irmã C., 2016)

Chegando ao outro acampamento escolhido pelo INCRA, a cerca de $50 \mathrm{~km}$ de distância, foram

catá o pouco que restou, montá barracas e decidir o qui fazê. (Irmã C., 2016)

$\mathrm{Na}$ verdade estava começando mais uma luta. Meses depois, inconformados com aquela situação e com o fracasso da primeira ocupação, retornaram à Fazenda Chapadinha, agora 39 famílias, e enfrentaram, na justiça, a luta pela posse da terra. Muitas famílias se dispersaram, seguindo outros caminhos. 
Figura 9 - Famílias do Assentamento Chapadinha-DF.

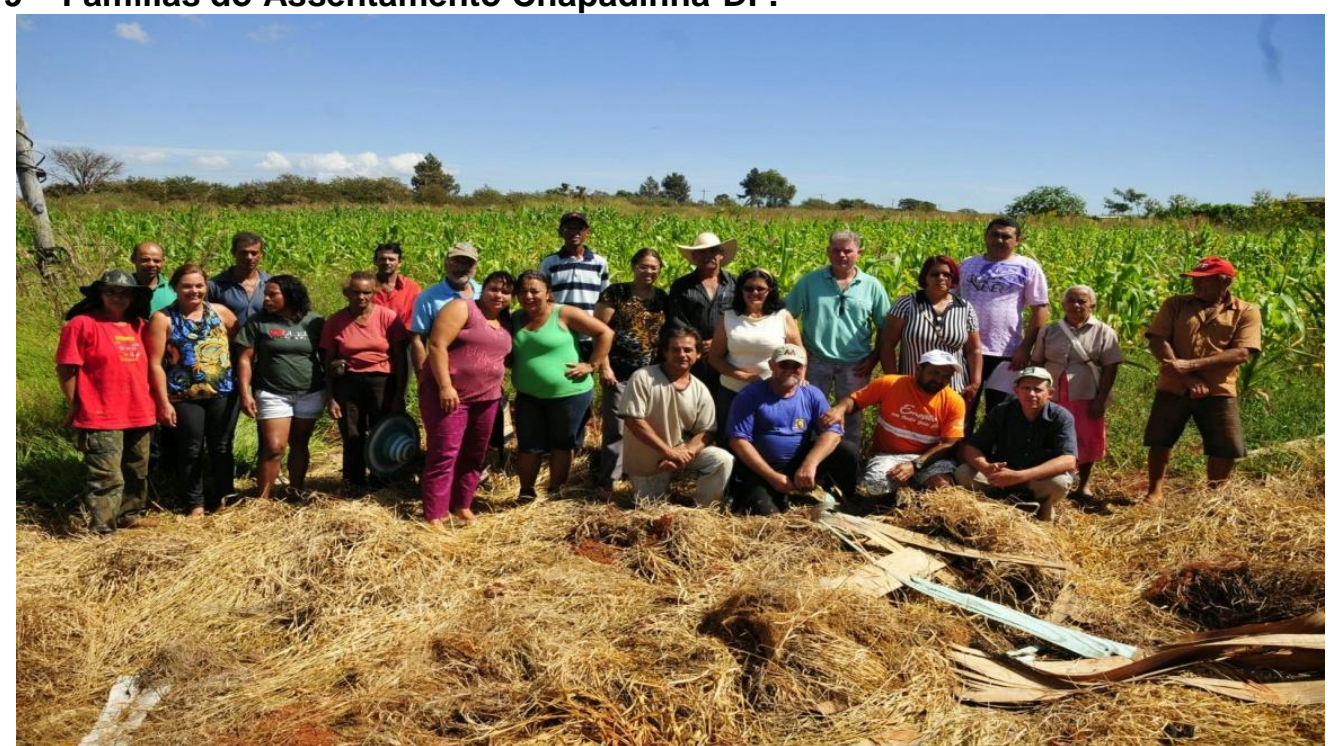

Fonte: <http://emicles.blogspot.com.br/2014/05/df-sem-miseria-melhora-vida-de.html>. Acesso em: 15 dez. 2016.

\subsubsection{A regularização esperada}

O Assentamento Chapadinha é o primeiro da reforma agrária agroecológico no Distrito Federal, e está em fase final de estruturação, conforme trâmites legais junto ao INCRA.

Hoje, o Assentamento Chapadinha está classificado como PAs (Projetos de Assentamento), ou seja, aguardando a regularização, de acordo com o INCRA, órgão executor da reforma agrária e ordenador fundiário nacional. Nesse estágio, como "acampado", a comunidade tem acesso às políticas públicas do Programa de Assentamento de Trabalhadores Rurais (PNRA). Aqui, no Distrito Federal, esse programa é supervisionado pela Secretaria de Agricultura, Abastecimento e Desenvolvimento Rural (SEAGRI-DF). Porém, o acesso aos serviços de saneamento, eletrificação, construção definitiva das moradias, e outros, só será possível após a devida regularização como assentamento. Para "tocar" a lavoura, os agricultores utilizam a água dos poços e dos tanques, improvisam eletricidade a partir da rede que atende as chácaras do Lago Oeste, recebem atendimento médico e odontológico da Associação dos Produtores do Lago Oeste (Asproeste) e usam o transporte coletivo que atende também ao Núcleo Rural do Lago Oeste. A 
regularização como "Assentado" permite o acesso definitivo à terra, política de aplicação de crédito, assistência técnica e orientações sobre os meios de preservação e conservação dos recursos naturais, conforme figura abaixo.

Figura 10 - Processo de regularização dos assentamentos.

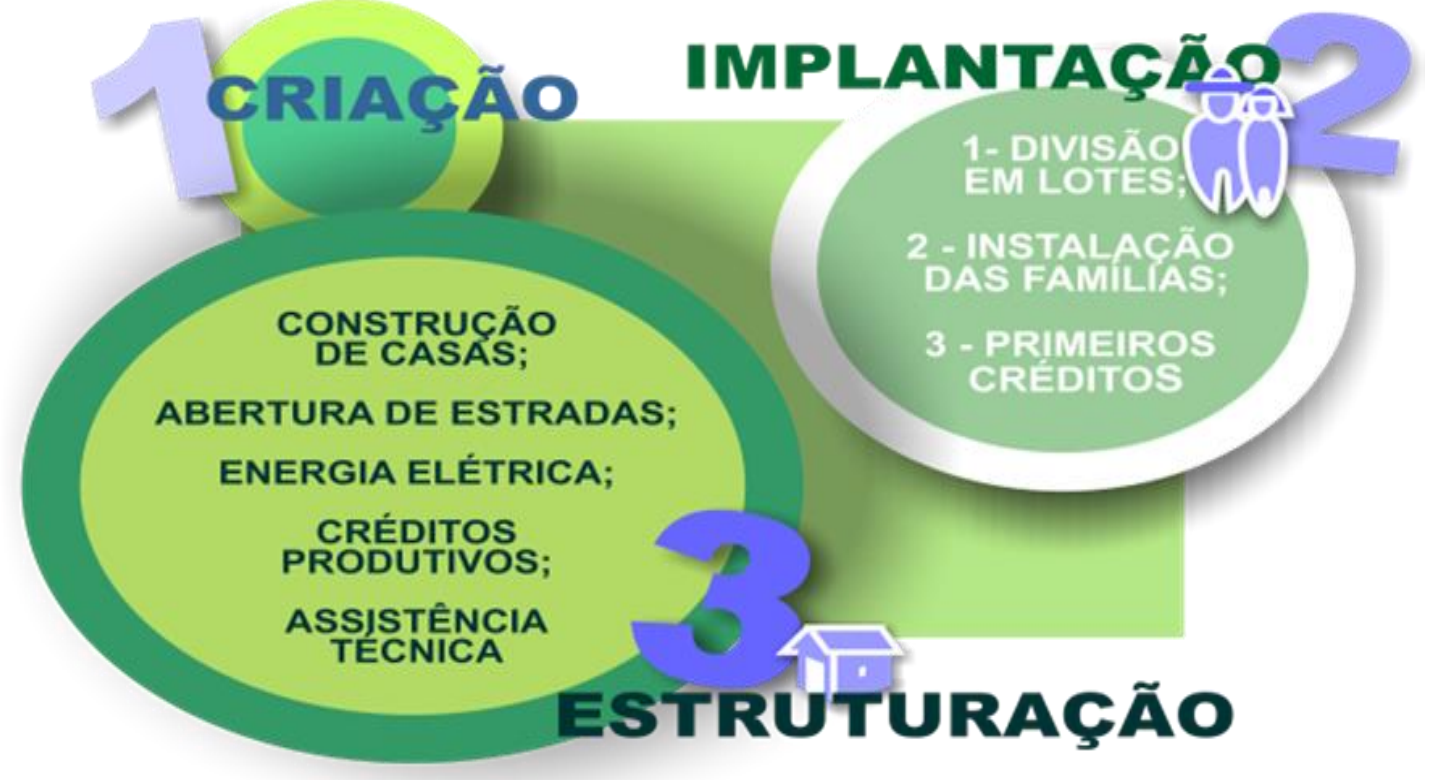

Fonte: <http://www.incra.gov.br/assentamento>. Acesso em: 17 jan. 2016.

\subsubsection{Associativismo e produção orgânica}

O Assentamento Chapadinha é filiado à Federação Nacional dos Trabalhadores e Trabalhadoras na Agricultura Familiar (Fetraf-Brasil/CUT), que tem como objetivos principais o fortalecimento e a ampliação da representação dos agricultores e agricultoras familiares do Brasil e a unificação da ação sindical cutista, tendo como eixo central o fortalecimento da agricultura familiar e a construção de um projeto de desenvolvimento sustentável e solidário. A Fetraf atua em quatorze Estados; e aqui, no Distrito Federal, é coordenado pelo agricultor Anaildo Porfirio da Silva, presidente da Associação dos Trabalhadores Rurais do Assentamento Chapadinha (Astraf-DF).

A Astraf-DF foi criada em 2008, com 42 famílias, com o objetivo de captar recursos para apoiar a comunidade nos diversos projetos comunitários, sendo 
constituída legalmente com o apoio da Fetraf-DF. Em 2012 foi criada a Organização de Controle Social Chapadinha com o apoio da Fetraf, Emater e Sebrae do Distrito Federal, e cadastrada no Ministério da Agricultura, com o objetivo de possibilitar a venda direta ao consumidor da produção orgânica ${ }^{9}$.

Das 47 unidades de produção do assentamento, 28 estão registradas no Ministério da Agricultura, Pecuária e Abastecimento (MAPA) como produtor orgânico, por meio do programa de Produção Agroecológica Integrada Sustentável (PAIS). Esse Programa apoia a produção agrícola sem uso de agrotóxicos, integrada com a criação de animais e utilização de insumos produzidos na própria propriedade. Desta forma, preserva a qualidade do solo e as fontes de água e garante alimentação saudável e renda para os produtores.

Trata-se de uma tecnologia social que está sendo reaplicada em diversas regiões do estado. Com baixo custo, tem como premissa o manejo orgânico da produção, fugindo da produção convencional e incentivando os agricultores a adotarem em sua propriedade uma policultura. $O$ projeto é uma parceria entre a Federação dos Trabalhadores na Agricultura (Feta), a Fundação Banco do Brasil e o Banco Nacional do Desenvolvimento Econômico e Social (BNDES), e conta com o apoio do Sebrae, que tem contribuído para a transformação socioeconômica de várias comunidades rurais e, consequentemente, para a melhoria da qualidade de vida dos agricultores.

O PAIS possui baixo custo e adota um modelo de cultivo que consiste em um sistema circular em cujo centro há um espaço para a criação de pequenos animais, no caso, galinhas caipiras. O esterco produzido pelas aves é utilizado para adubar a horta, e os ovos para alimentação e/ou comercialização. No entorno do galinheiro são preparados os canteiros. Para implantação do sistema PAIS, é analisada a prospecção do potencial produtivo de cada unidade selecionada e, posteriormente, são implementados os sistemas de produção de acordo com as potencialidades identificadas em cada área, visando valorizar a agricultura familiar; produzir alimentos limpos e sadios; implantar sistema agroecológico de produção; promover o desenvolvimento rural sustentável e solidário; propiciar retorno econômico e social;

\footnotetext{
${ }^{9}$ Fetraf-Brasil/CUT DF (Federação Nacional dos Trabalhadores e Trabalhadoras na Agricultura Familiar; Emater - DF (Empresa de Assistência Técnica e Extensão Rural do Distrito Federal); Sebrae (Serviço Brasileiro de Apoio às Micro e Pequenas Empresas).
} 
promover política de geração de emprego e renda. Dois pilares do PAIS se destacam dentro dos pressupostos desta pesquisa:

$\checkmark$ dar visibilidade às políticas de geração e gênero (mulheres, jovens e terceira idade); e

$\checkmark$ propiciar meios de permanência da mulher, do homem, e do jovem rural no campo.

Alguns produtores rurais do assentamento ainda não estão cadastrados no programa.

A Astraf foi selecionada para participar do Programa Nacional de Alimentação Escolar (PNAE), por meio da chamada pública da entidade executora, Instituto Federal de Educação, Ciência e Tecnologia de Brasília (IFB), devido à produção dos agricultores familiares com manejo sustentável e utilização de práticas agroecológicas.

Os agricultores familiares do assentamento têm mercado garantido com as compras públicas dos programas Nacional de Alimentação Escolar (PNAE) e de Aquisição de Alimentos (PAA), que propicia a aquisição de alimentos da agricultura familiar com dispensa de licitação e é executado por seis modalidades definidas por um Comitê Gestor. Em 2012 foi criada a modalidade "Compra Institucional”, que é o uso do poder de compra do Estado junto a agricultura familiar, o que pode permitir o acesso dos agricultores e suas organizações produtivas (cooperativas e associações) no mercado, gerando inclusão social, fortalecimento de redes de comercialização de circuitos curtos, qualificação de processos produtivos e consolidação das políticas públicas de fortalecimento da agricultura familiar e segurança alimentar e nutricional.

As políticas públicas têm contribuído efetivamente na vida dos assentados. Dentre outros exemplos, temos os depoimentos do produtor $\mathrm{V}$, beneficiado pelos programas governamentais, o qual declara que "com os recursos das cestas básicas", pagou o IPVA e as parcelas do seu caminhão. Outro agricultor relata que hoje recebe mais no campo do que recebia em seu emprego de lanterneiro na cidade. 


\section{ANÁLISE DA PESQUISA}

A fim de responder aos pressupostos desta pesquisa, traduzidos nos objetivos, problemas e questões, esta pesquisadora recorreu aos procedimentos metodológicos já descritos, os quais possibilitaram desvendar as interrogações já enunciadas.

No primeiro momento, a literatura apontou que o turismo rural de base comunitária no Brasil tem em comum as lutas sociais, com foco na conservação dos recursos naturais, base da subsistência de diversas comunidades, a luta pela posse da terra, pelo direito à memória cultural e a luta por uma educação digna.

No assentamento Chapadinha-DF, esta pesquisadora observou que a comunidade traz consigo o orgulho pela conquista da terra, pelo enfrentamento das forças legalmente instituídas para impedir a invasão daquela área até então destinada a um único dono e à monocultura. Uma declaração da agricultora Irmã C. traduz este sentimento quando identifica o local onde se juntaram para impedir o acesso do grileiro e seus capangas, e diz: "ali começou a luta e por isso deve ser construída uma igreja".

A trajetória de luta vivida pelos assentados se relaciona ao turismo rural comunitário, de acordo com Coriolano (2009), pois forma uma base para o desenvolvimento de "um outro turismo".

O turismo, nas unidades de agricultura familiar, configura-se como não agrícola dentro do conceito da pluriatividade. Ele possibilita a promoção, a manutenção e a reprodução socioeconômica das formas tradicionais de produção familiar nessas regiões. A partir do turismo, as propriedades familiares passam a ser vistas como sistemas produtivos e orgânicos aos quais são agregadas as novas atividades, necessariamente interligadas e integradas numa proposta concreta de sustentabilidade local e geração de emprego e renda no campo. Além disso, há o interesse dos visitantes de outras regiões pelo patrimônio sociocultural local.

A terra e a produção agroecológica do assentamento têm contribuído para melhorar as condições de vida dos agricultores. Há depoimentos de um agricultor neste sentido, ao dizer que "tudo está melhorando, consegui até convencer meus dois filhos a abandonarem seus trabalhos na cidade para me ajudar na produção. 
Meu roçado é a minha paixão". Assim se expressa o sentimento de pertencimento (ZAOUAL, 2008) e de orgulho em relação às suas próprias tradições e costumes.

As "novas ruralidades" (GRAZIANO, 2002) aproveitam e expandem novas funções e atividades no campo, integrando e envolvendo as familiais rurais com o poder público e a iniciativa privada. Trata-se da pluriatividade rural e da multifuncionalidade do campo, como é classificado esse novo momento no meio rural brasileiro.

O fenômeno da pluriatividade pode, também, levar a uma reorientação do modelo de desenvolvimento do meio rural brasileiro, diante da crescente preocupação mundial com o meio ambiente, por meio de políticas públicas direcionadas. Essa reorientação pode vir por meio de um modelo autossustentável, ecologicamente correto e socialmente igualitário, proporcionando a fixação e a manutenção de famílias no campo, ligadas a atividades como a agricultura orgânica, prática agroecológica predominante no Assentamento de Chapadinha-DF, objeto desta pesquisa sendo este o primeiro da reforma agrária agroecológica no Distrito Federal, de acordo com o INCRA.

A comercialização da produção orgânica aumentou em $50 \%$ a renda das famílias agricultoras, a partir de 2012, conforme informação do ex-Presidente da Astraf. A comunidade expressa seu envolvimento com a sustentabilidade também na preservação das nascentes ali localizadas, com medidas de reflorestamento e isolamento dos impactos humanos.

Ainda no contexto da pluriatividade, a agroecologia, o turismo rural, o ecoturismo, as práticas de esporte ligadas à natureza, o artesanato e os pequenos beneficiamentos de alimentos são atividades fortemente incentivadas por práticas de associativismo e de mecanismos de extensão e capacitação. Essas atividades encontram respaldo nos pressupostos da presente pesquisa, tendo em vista 0 espaço geográfico em que o Assentamento Chapadinha se situa, onde predomina recursos naturais de relevante interesse ecoturístico, ou seja, na região da Chapada da Contagem.

Assim, várias outras modalidades do turismo estão sendo criadas, adequadas às tradições culturais e ao espaço natural das regiões. O turismo alternativo, ecológico, agroturismo, entre outros, são modelos de turismo identificados como turismo rural e que se associam aos agricultores familiares. No turismo rural, o produtor passa a ser um empreendedor e prestador de serviços que, ao mesmo 
tempo, dedica-se à conservação do patrimônio ambiental e cultural de sua região, valor maior na oferta turística rural. O estilo de vida, os costumes e o modo de produção das famílias rurais, ou seja, a cultura do campo, o compartilhamento de tradições gastronômicas e culturais é resgatado e valorizado e revertido em diversificação de trabalho e renda para a comunidade.

Esta pesquisadora observou que a vocação agrícola não se faz presente em todos os assentados de Chapadinha-DF. Isto os leva a se ocupar em outras atividades de trabalho fora do assentamento. São homens, mulheres, jovens e idosos, que apresentam possibilidades de alguma atuação em atividade de turismo rural naquele espaço. Outro dado importante diz respeito a dificuldades nas condições físicas para o trabalho agrícola, que se apresentam em alguns agricultores, devido à idade. É o caso, por exemplo, da Irmã C., que, ao responder a indagação desta pesquisadora quanto ao turismo no assentamento, diz que "talvez fosse bom para mim trabalhar recebendo os visitantes, contando histórias da luta pela terra e, quem sabe, preparar uma comida caseira, porque já estou me sentindo velha para trabalhar na plantação".

É a visão pluriativa rural convergente com o turismo na comunidade. O caráter multifuncional da atividade agrícola também é visível no Assentamento. No primeiro momento, têm-se as políticas de transferência de renda, mediante os programas oficiais já referidos nesta pesquisa, que são fundamentais para a reprodução das famílias assentadas. No segundo momento, as políticas públicas têm o papel de fomentar a organização dos produtores e viabilizar a comercialização da sua produção, atuando como divulgadoras e certificadoras dos produtos originários das unidades familiares. Esse tipo de desenvolvimento rural torna-se sustentável a partir da inserção dos produtores familiares em um novo mercado, estimulado pelo estado.

O enfoque atual da multifuncionalidade justifica tanto ações de conservação ambiental e sociocultural como também ações protecionistas.

As ações protecionistas da multifuncionalidade agrícola se confirmam na região do Lago Oeste a partir das políticas de conservação na Reserva Biológica da Contagem, que forma um corredor ecológico com o PARNA Brasília e o Núcleo Rural Lago Oeste (NRLO). Também as práticas agroecológicas dos assentados demonstram um compromisso com a sustentabilidade sócio-ambiental, com destaque para as mulheres agricultoras que vivenciam experiências bem-sucedidas 
no cultivo orgânico de hortaliças, ratificando o propósito de promover a segurança e a soberania alimentar para as suas famílias e sociedade.

Nesse segmento do turismo na agricultura familiar, os agricultores são os maiores protagonistas de seu desenvolvimento, e também os maiores beneficiários, a partir da participação dos camponeses/agricultores familiares no planejamento e gestão do turismo rural.

\subsection{VOZES DAS MULHERES}

O turismo rural pôde ser percebido, por esta pesquisadora, como um vetor dessa busca feminina por visibilidade tanto no âmbito do assentamento, quanto da sociedade na qual essas mulheres se inserem por meio do "olhar do turista". Essa tomada feminina do espaço público apareceu nesta pesquisa como a possibilidade de ampliação das trocas simbólicas e valorização da identidade local. Em alguns depoimentos dados por elas, fica nítida a importância da ampliação do convívio social para além da esfera local significa, do ponto de vista da sociabilidade.

Ao perguntar à Irmã C. sobre a visitação turística no assentamento, ela afirmou: "É bom. Daqui um tempo eu não vou conseguir trabalhar na plantação por causa da idade, então eu posso conversar com os turistas, contar a história do assentamento, a nossa luta, mostrar as fotos...". Outras assentadas veem com entusiasmo a possibilidade de se inserir programa de visitação turística naquele núcleo. A agricultora F. e sua filha apresentam uma vocação empreendedora e, nesse sentido, planejam a criação de outra associação ou reestruturação do Grupo Raízes da Terra, a construção de uma sede com infraestrutura adequada a cursos de capacitação e treinamento, produção de artesanato e processamento de alimentos (pães, biscoitos, doces, geleias, e outros).

A agricultora F. demonstrou entusiasmo com a possibilidade de ampliar sua renda (que hoje se baseia na comercialização dos produtos agrícolas) com os serviços demandados pela atividade turística. Ela terceiriza muitas atribuições do campo e se dedica mais à administração do plantio e comercialização dos produtos. Sua atuação no campo é maior como administradora do que como agricultora. No entanto, outras agricultoras declararam não pretender abandonar o trabalho de plantio 
por se considerarem realizadas como produtoras e provedoras da família. Uma delas é a agricultora L., que se orgulha do seu papel como agricultora. No campo e em casa, ela decide todas as atividades. O marido é o principal ajudante; os netos auxiliam nos cuidados da casa e na feira. Ela decide até o pé de alface que vai colher para venda e diz: "virei agricultora familiar e trabalho prá mim mesma".

$\mathrm{O}$ trabalho de pesquisa favoreceu a esta pesquisadora identificar moradores sem vocação agrícola, porém com perfil adequado para o turismo rural e com disponibilidade de tempo. São assentados aos quais o turismo pode conceder uma nova opção para a complementação da renda, sem que saiam de sua comunidade, sem a sua associação às atividades domésticas e agrícolas.

Aqui se deve apontar que esse é um dos aspectos negativos do papel das mulheres no turismo rural. A inserção do turismo associado a outras atividades desvirtua o conceito da pluriatividade rural. Além disso, confirma a sobrecarga de trabalho atribuído às mulheres dentro dos conceitos do patriarcado.

O MST do Rio Grande do Sul lançou o Programa de Turismo MSTur, cujo objetivo principal é apresentar as experiências bem sucedidas que os assentamentos vêm produzindo, a partir da visibilidade alcançada junto aos simpatizantes do Movimento, além de demonstrar o modo de vida camponês sem encenações. Ao mesmo tempo, busca conscientizar os visitantes sobre a resistência e luta em busca da reforma agrária, o objetivo maior dos assentamentos rurais.

Essas práticas nos assentamentos rurais têm proporcionado visibilidade ao protagonismo das mulheres no desenvolvimento dessa atividade com grande destaque, conforme registros do MSTur. As mulheres desempenham as atividades domésticas (limpeza, cozinha), recepção, fornecimento de produtos beneficiados na unidade familiar, participação na gestão de restaurante e hospedagem, produção de artesanato, entre outras atividades. Porém, há registro do próprio MSTur de que as agricultoras acumulam tarefas agrícolas e domésticas com o turismo.

Mesmo com os avanços no âmbito feminista, o conceito cultural que predomina nas sociedades ocidentais ainda coloca a esfera alimentar sob o domínio essencialmente feminino. Portanto, notamos que a questão de gênero deva merecer destaque na discussão referente à implantação da atividade turística no meio rural. Esse saber-fazer alimentar as torna protagonistas nesse cenário, valorizando o trabalho realizado pelas elas tanto dentro do espaço do assentamento quanto fora dali, pelos visitantes. 


\section{CONSIDERAÇÕES FINAIS}

Os conceitos de Geertz, utilizados por esta pesquisadora neste trabalho, tratam "as descrições etnográficas como 'construções de construções dos nativos', encaradas em termos das interpretações às quais pessoas de uma denominação particular submetem suas experiências". Isso porque "somente o nativo faz interpretação de primeira mão". A interpretação do que acontece, segundo o autor, não pode se distanciar daquilo que acontece.

O percurso etnográfico deste trabalho permitiu, nas palavras de Geertz (1989), um mergulho no meio da comunidade que representa o Assentamento Rural de Chapadinha, conduzindo a uma melhor percepção da realidade, à reconstrução histórica do processo de luta e conquista da terra, às lembranças da vida, da memória e do cotidiano dos assentados rurais.

Esse caminho propiciou uma aproximação com a organização da pequena produção familiar rural e com o lugar das mulheres nos espaços dessa produção e fora dela. Trata-se de um contexto rural onde se vivencia a prática da solidariedade; da convivência familiar; do respeito ao outro, à terra, ao meio ambiente, refletido no trabalho harmonioso da agroecologia. Um lugar onde a singularidade do acolhimento e da hospitalidade se faz presente.

O turismo rural tem sido apontado como uma promissora alternativa de emprego e renda para as famílias agrícolas, sendo considerada uma atividade que dinamiza economicamente os espaços rurais. É, também, visto como potencialmente sustentável, pois além dos benefícios econômicos, pode contribuir para a conservação ambiental e para o resgate e valorização sociocultural das comunidades e famílias rurais.

No entanto, a prática do Turismo Rural, mesmo caracterizado como de uma abordagem social com fins de auxiliar e promover melhorias no meio em que se é praticado, ainda é observado com o escopo mercadológico. Entendemos que é de extrema importância ressaltar os impactos negativos ao meio rural oriundos da visão capitalista do turismo.

Esse posicionamento vai ao encontro da abordagem feita do turismo como um fenômeno social, como um processo humano (MOESCH, 2002). 
Por outro lado, Candiotto (2013) aponta o turismo rural como uma promissora alternativa de emprego e renda para as famílias agrícolas, pois ele é considerado uma atividade que dinamiza economicamente os espaços rurais.

É importante apontar as deficiências e riscos da oferta turística comunitária que resultam, em parte, da incursão das comunidades no turismo em situações de improviso, da ausência de profissionalismo e do desconhecimento do mercado e dos instrumentos de gestão de negócios.

Portanto, há que se ponderarem os riscos e os pontos fracos desse segmento, no sentido de conduzi-lo para iniciativas que operem em condições de sustentabilidade, dentro de um contexto de programas que conduzam a benefícios econômicos, sociais e ambientais para as comunidades envolvidas. Esta pesquisadora constatou que há certa ilusão, ou uma perspectiva muito otimista com relação aos benefícios do turismo rural. Portanto, cabe ao planejador turístico, atentar para os aspectos positivos e negativos deste fenômeno do meio rural, e munir a comunidade dos instrumentos possíveis para conduzir o turismo de forma consciente.

O turismo rural é entendido pelas mulheres como uma nova opção para a complementação da renda, sem que elas tenham de sair de sua comunidade, associando as atividades domésticas e agrícolas com as atividades relacionadas ao turismo. Porém, o cenário feminino do assentamento Chapadinha demonstra que as mulheres já conquistaram uma posição de autonomia econômica e de segurança quanto ao seu papel na sociedade. A aproximação desta pesquisadora com as agricultoras permite considerar que, em sua maioria, elas têm o poder de decisão sobre os seus atos. A maioria das mulheres vivem sós, separadas dos maridos por questões de agressões as mais diversas. Portanto, a sujeição ao poder masculino não encontra espaço em suas vidas. Isto leva a acreditar que em relação às mulheres, a prática turística no assentamento poderá estabelecer com autonomia, divisão sexual no trabalho e equidade nos ganhos financeiros.

A luta pela conquista da terra fortaleceu as mulheres do assentamento Chapadinha-DF. Elas moram em barracos improvisados, com pouco conforto, trabalham sob o sol ou a chuva no cultivo da terra, e se sentem orgulhosas com os resultados dos seus trabalhos. Esta trajetória de luta, já abordada aqui, levou essas mulheres a se posicionarem como sujeitos políticos nas esferas pública e privada. Elas participam dos movimentos sociais reivindicando direitos e atendimento às suas 
demandas sociais. A Marcha das Margaridas é um exemplo desses movimentos. Esse movimento já conquistou muito espaço político para as mulheres rurais, tais como direito à posse da terra, financiamento para o trabalho agrícola, dentre outros.

O ecofeminismo se revela no dia a dia das agricultoras rurais, a partir da preocupação com a produção orgânica, do cuidado com as nascentes, da práticas de preservação ambiental dentro dos seus espaços. A consciência feminista e ecofeminista se situa nos seguintes pressupostos: autonomia financeira, não submissão à dominação masculina, autonomia na tomada de decisões no campo, ser respeitada pelos homens em quaisquer circunstâncias.

Para assegurar os seus direitos dentro da comunidade rural, as agricultoras se mantêm atentas, vigilantes e participativas em todas as decisões da Associação. Enfrentam problemas internos, mas sempre persistem em lutar pelos seus direitos.

Assim, quanto às questões colocadas nesta pesquisa, e com base no trabalho de campo desenvolvido por esta pesquisadora, constata-se que o turismo rural poderá ampliar a visibilidade e o empoderamento das mulheres assentadas, a partir da atuação direta ou indireta neste setor.

No entanto, importa dizer que a produção agroecológica das mulheres já Ihes proporciona visibilidade no ambiente privado e público e empoderamento, assegurando-Ihes seu próprio sustento e, para algumas, de suas famílias. $\mathrm{O}$ turismo, em princípio, seria significativo apenas para um pequeno número de mulheres que optaria por substituir o trabalho do campo. A atividade turística poderá beneficiar os jovens.

Por fim, deixa-se aqui registrado o depoimento de uma agricultora, que retrata uma consciência ecofeminista na dimensão política e social, a partir do seu reconhecimento pelo alcance nas políticas sociais do governo. Esta pesquisadora teve o privilégio de ouvir das agricultoras a determinação na busca e defesa de todos os seus direitos como mulheres e cidadãs e, ao mesmo tempo, exercer o direito e o dever de contribuir para a sustentabilidade em suas amplas dimensões.

Agora são apenas sorrisos, a vida está muito melhor. Os programas foram fazendo a vida melhorar. Com o PAA (Programa de Aquisição de Alimentos) consegui comprar minha geladeira, máquina de lavar. Agora, com o PAPA (Programa de Aquisição da Produção de Agricultura) e a venda dos alimentos para as cestas, estou conseguindo melhorar ainda mais minha renda e investir mais na produção. Vou conseguir financiar até uma picape. ( $F, 2016)$ 
Já estou me organizando para devolver meu cartão do Bolsa Família. Esse dinheiro me ajudou a manter minha casa, comprar meus remédios. Meus filhos conseguiram terminar o $2^{\circ}$ grau. Agora eu quero voltar a estudar também. Quero devolver meu cartão, porque quero que outras pessoas possam ser ajudadas. ( $F, 2015)$ 


\section{REFERÊNCIAS}

ABRAMOVAY, Ricardo. Diversificação das economias rurais no Nordeste. Relatório final para o Ministério do Desenvolvimento Agrário, Núcleo de Estudos Agrários e Desenvolvimento Rural - NEAD, Projeto Políticas Públicas e Desenvolvimento Rural, Balanço da Ação Governamental no Brasil - PCT IICA/NEAD. São Paulo; Brasília, julho de 2002.

AMARO, Rogério Roque. A exclusão hoje. Cadernos do ISTA, Instituto São Tomás de Aquino, n. 9. Disponível em: <http://www.triplov.com/ista/cadernos/cad_09/ amaro.html>. Acesso em: 23 mai. 2016.

ARAÚJO, Neuza de Farias. Contribuição econômica das mulheres para a família e a sociedade: ensaio sobre gênero e economia numa perspectiva comparativa. Brasília: Otimismo, 2010.

ARAÚJO, Neuza de Farias; TROMBINI, Raquel da Silva. As condições de trabalho das diaristas na cidade de Brasília. Revista Fazendo Gênero 10: desafios atuais do feminismo. Florianópolis: Editora da UFSC, 2013. v. 1. p. 106-116.

BARTHOLO, Roberto. Sobre o sentido da proximidade: implicações para um turismo situado de base comunitária. In: BARTHOLO, Roberto; SANSOLO, Davis Gruber; BURSZTYN, Ivan (Orgs.). Turismo de base comunitária: diversidade de olhares e experiências brasileiras. Rio de Janeiro: Letra e Imagem, 2009. p. 45-54.

BARTHOLO, Roberto; SANSOLO, Davis Gruber; BURSZTYN, Ivan (Orgs.). Turismo de base comunitária: diversidade de olhares e experiências brasileiras. Rio de Janeiro: Letra e Imagem, 2009.

BLANCO, E. O turismo rural em áreas de agricultura familiar: as "novas ruralidades" e a sustentabilidade do desenvolvimento local. In: BARTHOLO, Roberto; SANSOLO, Davis Gruber; BURSZTYN, Ivan (Orgs.). Turismo de base comunitária: diversidade de olhares e experiências brasileiras. Rio de Janeiro: Letra e Imagem, 2009. p. 348358.

BRASIL. Lei n. 4.504, de 30 de novembro de 1964. Dispõe sobre o Estatuto da Terra, e dá outras providências. Brasília: Diário Oficial da União, 31 nov 1964.

BRASILEIRO, lara Lúcia Gomes. Turismo e desenvolvimento sustentável. Correio Braziliense, Brasília-DF, 12 dez. 2004. 
BRUYNE, Paul de; HERMAN, Jacques; SHOUTHEETE, Marc de. Dinâmica da pesquisa em ciências sociais: os polos da prática metodológica. Rio de Janeiro: Francisco Alves, 1982.

BURSZTYN, Ivan; BARTHOLO, Roberto; DELAMARO, M. Turismo para quem? Sobre caminhos de desenvolvimento e alternativas para o turismo no Brasil. In: BARTHOLO, Roberto; SANSOLO, Davis Gruber; BURSZTYN, Ivan (Orgs.). Turismo de base comunitária: diversidade de olhares e experiências brasileiras. Rio de Janeiro: Letra e Imagem, 2009. p. 76-91.

CANDIOTTO, Luciano. O discurso da viabilidade do turismo rural na agricultura familiar: O Programa Nacional de Turismo Rural na Agricultura Familiar (PNTRAF) e o papel do Estado do Paraná no contexto. Revista de Cultura e Turismo, ano 7, n. 02, jun. 2013. Disponível em: <http://www. uesc.br/revistas/culturaeturismo>. Acesso em: 26 jun. 2016.

CARBONELL, Lucia Ramón. Ecofeminismos y teologías de la liberación. Papeles de relaciones ecosociales y cambio global, n. 125, p. 101-109, 2014.

www.fuhem.es/media/cdv/file/biblioteca/revista_papeles/125/Ecofeminismos_y_teolo gias_de_la_liberacion_L_Ramon_Carbonell.pdf>. Acesso em: 26 jun. 2016.

CEPAL. Anuário estadístico de América Latina y el Caribe, 2008. Disponível em: <http://www.cepal.org/publicaciones/xml/7/35327/anuario2008.pdf>. Acesso em: 26 jun. 2016.

COMISSÃO MUNDIAL SOBRE O MEIO AMBIENTE E DESENVOLVIMENTO. Nosso futuro comum. 2. ed. Rio de Janeiro: Fundação Getúlio Vargas, 1991.

CORALINA, Cora. Poemas dos becos de Goiás e estórias mais. 23. ed. São Paulo: Global, 2006.

CORIOLANO, Luzia Neide M. T. O turismo comunitário no nordeste brasileiro. In: BARTHOLO, Roberto; SANSOLO, Davis Gruber; BURSZTYN, Ivan (Orgs.). Turismo de base comunitária: diversidade de olhares e experiências brasileiras. Rio de Janeiro: Letra e Imagem, 2009. p. 277-288.

CRESWELL, John W. Projeto de pesquisa: métodos qualitativo, quantitativo e misto. Trad. de Magda Lopes. 3 ed. Porto Alegre: Artmed, 2010.

CRISTÓVÃO, Artur; PEREIRO, Xerardo (Orgs.). Atas do VIII CITURDES: turismo rural em tempos de novas ruralidades. Chaves (Portugal): Universidade de Trás-osMontes e Alto Douro (UTAD), 25-27 de junho de 2012. 
CRUZ, Rita de Cássia Ariza da. Turismo, produção do espaço e desenvolvimento desigual: para pensar a realidade brasileira. In: BARTHOLO, Roberto; SANSOLO, Davis Gruber; BURSZTYN, Ivan (Orgs.). Turismo de base comunitária: diversidade de olhares e experiências brasileiras. Rio de Janeiro: Letra e Imagem, 2009. p. $92-$ 107.

DEL GROSSI, Mauro Eduardo; GRAZIANO DA SILVA, José. Evolução da renda nas famílias agrícolas e rurais: Brasil, 1992-1997. In: CAMPANHOLA, Clayton; GRAZIANO DA SILVA, José (Eds.). O novo rural brasileiro: uma análise nacional e regional. Jaguariúna: EMBRAPA, 2000, v. I, p. 79-100.

DEMO, Pedro. Metodologia do conhecimento científico. São Paulo: Atlas, 2000.

DENCKER, Ada Freitas Maneti de. Métodos e técnicas de pesquisa em turismo. 4. ed. São Paulo: Futura, 2000.

DENCKER, Ada Freitas Maneti de. Pesquisa em turismo: planejamento, métodos e técnicas. 9. ed. São Paulo: Futura, 2007.

FEITOSA, Dennis Regis S. et al. Perfil socioeconômico e cultural de mulheres dos assentamentos rurais de Sossego-PB. Disponível em:

$<$ ttp://www.scielo.br/scielo.php?script=sci_nlinks\&ref=000178\&pid=S0102-

$690920030001000080002>$. Acesso em: $0 \overline{4}$ dez. 2016.

FOUCAULT, Michel. A ordem do discurso. 15. ed. São Paulo: Edições Loyola, 2007.

FRANCISCO, Papa. Carta Encíclica Laudato sí: sobre os cuidados da casa comum. Vaticano, Libreria Editrice Vaticana; Paulinas, 2015. Disponível em: <http://w2.vatican.va/content/francesco/pt/encyclicals/documents/papafrancesco_20130629_enciclica-lumen-fidei.html>. Acesso em: 21 jun. 2015.

FULLER, Anthony M. From part-time farming to pluriactivity: a decade of change in rural Europe. Journal of Rural Studies, v. 6, n. 4, p. 361-373, Londres, 1990. Disponível em: <http://iuees.ufcg.edu.br/wp-content/uploads/2011/08/perfilsocioeconomico-e-cutural-de-mulheres-dos-assentamentos-rurais-de-sossegoPB.pdf>. Acesso em: 02 out. 2016.

FÚSTER, Luís Fernández. Introducción a la teoría y técnica del turismo. Madrid: Alianza Editorial, 2001.

GASTAL, Susana; MOESCH, Marutschka Martini. Turismo, imagens e imaginários. São Paulo: Aleph, 2007a. (Coleção ABC do Turismo). 
GASTAL, Susana; MOESCH, Marutschka Martini. Turismo, políticas públicas e cidadania. São Paulo: Aleph, 2007b. (Coleção ABC do Turismo).

GASTAL, Susana; MOESCH, Marutschka Martini. Turista cidadão: uma contribuição ao estudo da cidadania no Brasil. XXIX Congresso Brasileiro de Ciências da Comunicação, Universidade de Brasília, Brasília-DF, 2006. Disponível em: $<$ http://www.portcom.intercom.org.br/pdfs/153045190808854777 10823135712620658 2002.pdf>. Acesso em: 26 jan. 2016.

GAVIOLI, Felipe Rosafa; COSTA, Manoel Baltasar Baptista. As múltiplas funções da agricultura familiar: um estudo no assentamento Monte Alegre, região de Araraquara (SP). Revista Brasileira de Economia e Sociologia Rural, Brasília, v. 49, n. 2, p. 449472, jun. 2011. Disponível em: <http://dx.doi.org/10.1590/S0103-

20032011000200008 >. Acesso em: 15 mai. 2016.

GEERTZ, Clifford. 1926. A interpretação das culturas. Rio de Janeiro: LTC, 2008.

GIL, Antonio. Como elaborar projetos de pesquisa. 4. ed. São Paulo: Atlas, 2002.

GOLDENBERG, Mirian. A arte de pesquisar. como fazer pesquisa qualitativa em Ciências Sociais. 8. ed. São Paulo: Record, 2004.

GRAZIANO DA SILVA, José. O novo rural brasileiro. Campinas: UNICAMP/IE, 1999. (Coleção Pesquisas, 1).

IRVING, Marta de Azevedo. Reinventando a reflexão sobre turismo de base comunitária. Inovar é possível. In: BARTHOLO, Roberto; SANSOLO, Davis Gruber; BURSZTYN, Ivan (Orgs.). Turismo de base comunitária: diversidade de olhares e experiências brasileiras. Rio de Janeiro: Letra e Imagem, 2009. p. 108-121.

KRIPPENDORF, Jost. Sociologia do turismo: para uma nova compreensão do lazer e das viagens. São Paulo: Aleph, 2001.

LAKATOS, Eva Maria; MARCONI, Marina de Andrade. Fundamentos de metodologia científica. 6. ed. São Paulo: Atlas, 2006.

LAKATOS, Eva Maria; MARCONI, Marina de Andrade. Metodologia científica. São Paulo: Atlas, 2011.

LAKATOS, Eva Maria; MARCONI, Marina de Andrade. Metodologia do trabalho científico. 6. ed. São Paulo: Atlas, 2001. 
LAKATOS, Eva Maria; MARCONI, Marina de Andrade. Técnicas de pesquisa: planejamento e execução de pesquisas, amostragens e técnicas de pesquisas, elaboração, análise e interpretação de dados. 3. ed. São Paulo: Atlas, 1996.

LEFF, Enrique. Saber ambiental: sustentabilidade, racionalidade, complexidade, poder. 8ª . ed. Petrópolis: Vozes, 2011.

LUNARDI, Raquel; SOUZA, Marcelino de. Turismo e inovação no meio rural: visões a partir do território rural da região dos Campos de Cima da Serra. In: SCHNEIDER, Sérgio; GAZOLLA, M. (Orgs.). Os atores do desenvolvimento rural: perspectivas teóricas e práticas sociais. Porto Alegre: Editora da UFRGS, 2011. p. 221-233.

MALDONADO, Carlos. O turismo rural comunitário na América Latina: gênesis, características e políticas. In: BARTHOLO, Roberto; SANSOLO, Davis Gruber; BURSZTYN, Ivan (Orgs.). Turismo de base comunitária: diversidade de olhares e experiências brasileiras. Rio de Janeiro: Letra e Imagem, 2009. p. 25-44.

MARUJO, Noemi. Sociologia do Turismo na Educação Superior em Portugal. Turismo \& Sociedade, Curitiba, v. 6, n. 3, p. 490-507, jul. 2013.

MAUSS, Marcel. Sociologia e Antropologia. São Paulo: Cosac Naify, 2003.

MINAYO, Maria Cecília de Souza (Org.). Pesquisa social: teoria, método e criatividade. 29. ed. Petrópolis: Vozes, 2010. (Coleção Temas Sociais).

MINISTÉRIO DO TURISMO. Secretaria Nacional de Programas de Desenvolvimento do Turismo. Departamento de Qualificação e Certificação e de Produção Associada ao Turismo. Edital de chamada pública de projetos MTur/№ 001/2008. Brasília: Ministério do Turismo, 2008.

MOESCH, Marustchka. A produção do saber turístico. 2. ed. São Paulo: Contexto, 2002.

MOESCH, Marustchka. Turismo e lazer: conteúdos de uma única questão. In: MARCELLINO, Nelson Carvalho (Org.). Formação e desenvolvimento de pessoal em lazer e esporte. Campinas: Papirus, 2003. p. 19-30.

MOESCH, Marutschka. A epistemologia social do turismo. Tese (Doutorado em Turismo) - Escola de Comunicação e Artes, Universidade de São Paulo (USP), São Paulo, 2004.

MORIN, Edgar. Introdução ao pensamento complexo. 3. ed. Porto Alegre: Sulina, 
2007.

ORGANIZAÇÃO INTERNACIONAL DO TRABALHO. Mulheres no trabalho: tendências. Genebra, 2016.

PIMENTEL, Ana Bauberger. Dádiva e hospitalidade no sistema de hospedagem domiciliar. In: BARTHOLO, Roberto; SANSOLO, Davis Gruber; BURSZTYN, Ivan (Orgs.). Turismo de base comunitária: diversidade de olhares e experiências brasileiras. Rio de Janeiro: Letra e Imagem, 2009. p. 216-239.

PIRES, Lana Magaly. O fruto proibido e o pão: um estudo etnográfico no assentamento do contestado no Paraná. 2003. Tese (Doutorado em Programa de Estudos Pós Graduados em Ciências Sociais) - Pontifícia Universidade Católica de São Paulo, 2003.

PRONAF. Plano de Safra 2005/2006. Ministério do Desenvolvimento Agrário. Secretaria de Agricultura Familiar. 2005. Disponível em: <http://www2.faep/docs/pronaf_2005.pdf>. Acesso em: 26 jan. 2016.

RAMIRO, Patrícia Alves Ramiro; DIAS, Isabela Marcantonio. Identidade e turismo nos espaços rurais dos assentamentos de reforma agrária no Brasil. Revista Geográfica de América Central, n. esp., EGAL, 2011, Costa Rica, II Semestre 2011, pp. 1-16. Disponível em:

<http://www.revistas.una.ac.cr/index.php/geografica/article/download/1806/1712>. Acesso em: 16 jul. 2016.

RAMIRO, Patrícia Alves; DIAS, Isabela Marcantonio. Identidade e turismo nos espaços rurais dos assentamentos de reforma agrária no Brasil. Disponível em: <http://observatoriogeograficoamericalatina.org.mx/egal13/Geografiasocioeconomica /Geografiaagraria/02.pdf>. Acesso em: 26 jan. 2016.

REVISTA DE SAÚDE PÚBLICA. Faculdade de Saúde Pública da USP. São Paulo: v. 46, n. 5 , out. 2012.

REVISTA GEOGRÁFICA DE AMÉRICA CENTRAL, n. esp. EGAL, 2011, Costa Rica, II Semestre 2011, p. 1-16.

SACHS, Ignacy. Caminhos para o desenvolvimento sustentável. In: STROH, Paula Yone (Org.). Rio de Janeiro: Garamond, 2000.

SACHS, Ignacy. Desenvolvimento: includente, sustentável, sustentado. Rio de Janeiro: Garamond, 2008. 
SAFIOTTI, Heleieth lara Bongiovani, Gênero, patriarcado, violência. São Paulo: Fundação Perseu Abramo, 2004. (Coleção Brasil Urgente).

SANSOLO, Davis Gruber; BURSZTYN, Ivan. Turismo de base comunitária: potencialidade no espaço rural brasileiro. In: BARTHOLO, Roberto; SANSOLO, Davis Gruber; BURSZTYN, Ivan (Orgs.). Turismo de base comunitária: diversidade de olhares e experiências brasileiras. Rio de Janeiro: Letra e Imagem, 2009. p. 142161.

SANTOS, Maria Neila Ferreira dos; SILVA, Francisco Rosangelo Marcelino da; GONÇALVES, Flávio Henrique; JALFIM, Felipe Tenório. O turismo rural como fator de inclusão social das mulheres no assentamento Boa Vista em Quixadá-CE. II Seminário de Agroecologia de Pernambuco, 26 a 27 de abril de 2010, RecifePE/Brasil, 2010.

SCHNEIDER, Sergio. A importância da pluriatividade para as políticas públicas no Brasil. Revista de Política Agrícola, ano XVI, n. 3, jul.-set. 2010.

SCHNEIDER, Sergio. A pluriatividade na agricultura familiar. Porto Alegre: Editora da UFRGS, 2003.

SCHNEIDER, Sérgio. Teoria social, agricultura familiar e pluriatividade. Revista Brasileira de Ciências Sociais, v. 18, n. 51, fev. 2003.

SCOTT, Joan. Gênero: uma categoria útil para a análise histórica. Recife: SOS Corpo - Gênero e Cidadania, 1996.

SINGER, PAUL. Economia solidária versus economia capitalista. Brasília, 2001.

TRIVIÑOS, A. Introdução à pesquisa em ciências sociais: a pesquisa qualitativa em educação. São Paulo: Atlas, 2008.

WEISSHEIMER, Marco Aurélio. Economia solidária e felicidade interna bruta: as ideias de Paul Singer para enfrentar crise moral do capitalismo. rsurgente, 2015. Disponível em: <https://rsurgente.wordpress.com/2015/10/27/economia-solidaria-efelicidade-interna-bruta-as-ideias-de-paul-singer-para-enfrentar-crise-moral-docapitalismo/>. Acesso em: 26 jan. 2016.

ZAOUAL, Hassan. Do turismo de massa ao turismo situado: quais as transições? In: BARTHOLO, Roberto; SANSOLO, Davis Gruber; BURSZTYN, Ivan (Orgs.). Turismo de base comunitária: diversidade de olhares e experiências brasileiras. Rio de Janeiro: Letra e Imagem, 2009. p. 55-75. 


\title{
APÊNDICE I
}

\section{ROTEIRO DA ENTREVISTA SEMI-ESTRUTURADA APLICADA NO ASSENTAMENTO RURAL CHAPADINHA - DF}

\author{
01. NOME: \\ 02. IDADE: \\ 03. GRAU DE INSTRUÇÃO: \\ 04. ESTADO CIVIL: \\ 05. ESTADO DE ORIGEM: \\ 06. NÚMERO DE FILHOS: \\ 07. MORA SÓ OU ACOMPANHADO(A)? \\ 08. HÁ QUANTO TEMPO NO MOVIMENTO SEM TERRA? \\ 09. POR QUÊ ENTROU NO MOVIMENTO? \\ 10. PARTICIPOU DIRETAMENTE DA OCUPAÇÃO? \\ 11. FALE SOBRE A LUTA PELA OCUPAÇÃO \\ 12. O QUE PENSA SOBRE TERRAS NÃO PRODUTIVAS? \\ 13. QUAL ERA O SEU TRABALHO ANTES DA OCUPAÇÃO? \\ 14. É AGRICULTOR(A)? \\ 15. SATISFEITO COM A SUA PRODUÇÃO AGRÍCOLA? POR QUÊ? \\ 16. SUA RENDA MELHOROU COM A PRODUÇÃO AGRÍCOLA? \\ 17. PARTICIPA DOS MOVIMENTOS SOCIAIS? \\ 18. É BENEFICIÁRIO(A) DOS PROGRAMAS DO GOVERNO ? \\ 19. QUAIS PROGRAMAS? \\ 20. TRABALHA COM ALGUÉM NO CAMPO? \\ 21. SEUS PRODUTOS SÃO ORGÂNICOS? \\ 22. O QUE ACHA DA AGRICULTURA ORGÃNICA? \\ 23. O QUE PENSA SOBRE O TURISMO NO ASSENTAMENTO? \\ 24. DE QUE FORMA O TURISMO PODE AJUDAR A COMUNIDADE? \\ 25. O QUE SUGERE PARA ATRAIR O TURISTA? \\ 26. QUAL SERIA A PARTICIPAÇÃO DAS MULHERES NESSA ATIVIDADE?
}

